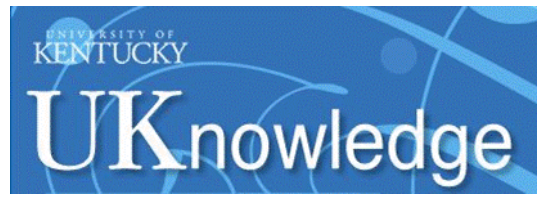

University of Kentucky

UKnowledge

\title{
The Right to Vote Under Local Law
}

Joshua A. Douglas

University of Kentucky, joshuadouglas@uky.edu

Follow this and additional works at: https://uknowledge.uky.edu/law_facpub

Part of the Election Law Commons

Right click to open a feedback form in a new tab to let us know how this document benefits you.

\section{Repository Citation}

Douglas, Joshua A., "The Right to Vote Under Local Law" (2017). Law Faculty Scholarly Articles. 615. https://uknowledge.uky.edu/law_facpub/615

This Article is brought to you for free and open access by the Law Faculty Publications at UKnowledge. It has been accepted for inclusion in Law Faculty Scholarly Articles by an authorized administrator of UKnowledge. For more information, please contact UKnowledge@lsv.uky.edu. 


\section{The Right to Vote Under Local Law}

\section{Notes/Citation Information}

Joshua A. Douglas, The Right to Vote Under Local Law, 85 Geo. Wash. L. Rev. 1039 (2017). 


\title{
The Right to Vote Under Local Law
}

\author{
Joshua A. Douglas*
}

\begin{abstract}
A complete analysis of the right to vote requires at least three levels of inquiry: the U.S. Constitution and federal law, state constitutions and state law, and local laws that confer voting rights for municipal elections. But most voting rights scholarship focuses on only federal or state law and omits any discussion of the third category. This Article-the first to explore in depth the local right to vote-completes the trilogy. Cities and towns across the country are expanding the right to vote in municipal elections to include sixteen-and seventeen-year-olds, noncitizens, nonresident property owners, and others. Berkeley, California, for example, recently lowered the voting age to sixteen for its school board elections.
\end{abstract}

This Article highlights these developments, encourages local voter expansions, and provides a test for courts to use when facing a judicial challenge to these rules. If states are "laboratories of democracy" that may experiment with social policies, then municipalities are "test tubes of democracy" that also can try out novel democratic rules, such as broadening the right to vote, on a smaller scale. Historically, some voter expansions, such as the elimination of property requirements and the women's suffrage movement, enjoyed early successes at the local level. Local voting rights, then, can serve as catalysts for broader reforms as they "trickle across" to other municipalities and "trickle up" to states and Congress.

As a matter of policy, local jurisdictions should enfranchise anyone who has a sufficient stake in local affairs and has the proper incentives and ability to make informed choices about who should lead them-which might include sixteen- and seventeen-year-olds, noncitizens (who are lawful permanent residents), nonresident property owners, felons, or others. States with barriers to local voting laws, through substantive voter qualifications or lack of "home rule" authorization to localities, should amend their state constitutional provisions or statutes. (An Appendix presents a fifty-state chart on the possibility in each state of enacting local voting laws.) Courts should defer to local laws that expand the right to vote as a means of local democracy, but should not defer to restrictions on the right to vote because limiting who may vote harms the

* Robert G. Lawson \& William H. Fortune Associate Professor of Law, University of Kentucky College of Law. I received great feedback when I presented this Article during faculty workshops at the University of Cincinnati and the University of Kentucky, as well as at the Washburn Law Journal Symposium on election law. Thanks to Richard Ausness, Cody Barnett, Paul Diller, Jim Donovan, Michael Hurta, Ned Foley, Rick Hasen, Cortney Lollar, Lisa Marshall Manheim, Michael Morley, Stephen Mortellaro, Ashira Ostrow, Mike Pitts, David Schleicher, Bob Schwemm, Michael Solimine, Nick Stephanopoulos, Franita Tolson, Bob Williams, and Andrew Woods for their insightful thoughts on earlier drafts. Thanks also to UK law librarian Beau Steenken for tracking down historical sources. Grant Sharp provided invaluable research assistance.

July 2017 Vol. 85 No. 4 
ideal of democratic inclusion. Robust protection of the right to vote depends on local voting rules as an early component of the reform effort. Enhanced local voting rights will produce a more representative local government, create a habit of voting for various groups-such as younger voters-that will ameliorate low turnout, and strengthen local democracy.

\section{TABle of Contents}

INTRODUCTION ................................... 1040

I. Localism as a Catalyst for Broader Change in Voting Rights: A Historical Perspective.......... 1045

A. Property Requirements ..................... 1046

B. Women's Suffrage......................... 1048

II. Modern Local Voting Reform ................. 1052

A. Lowering the Voting Age .................. 1052

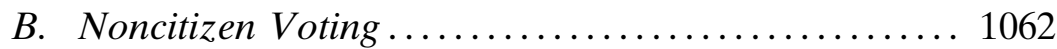

C. Nonresident Voting ...................... 1066

D. Other Voting Reforms Through Local Laws ....... 1068

III. Policy ANd LAw ............................ 1070

A. Benefits of Expanding the Electorate ............ 1070

B. Local Jurisdictions as "Test Tubes of Democracy” . 1073

C. Law................................... 1080

1. State Constitutional or Legislative Rules on

Voter Qualifications .................. 1082

2. Home Rule .............................. 1084

3. Judicial Interpretation of Local Laws Expanding the Franchise ...................... 1088

a. Federal Constitutional Challenges ......... 1088

b. State Constitutional or Statutory Challenges . 1091

4. Practical Difficulties in Expanding Local Voter

Qualification Rules ..................... 1097

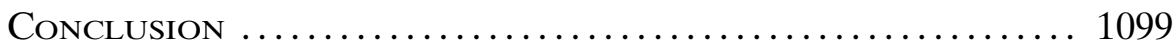

Appendix: Possibility of Local Laws Expanding the

Right to Vote in the Fifty States (and D.C.) .... 1101

\section{INTRODUCTION}

In an episode of the television show The West Wing, middle school students from a fictional children's advocacy group called "Future Leaders for Democracy" try to convince White House Communications Director Toby Ziegler that children should enjoy the right to 
vote. ${ }^{1}$ After largely agreeing with their various substantive arguments for children's suffrage, Toby strategizes, "Well, I'd go for lowering the age in increments and I wouldn't start at the federal level."”

The real-life push for expanded suffrage has tracked Toby's advice. Throughout the country, local jurisdictions are debating whether to expand the right to vote in local elections for various constituencies, such as younger Americans, noncitizens, and nonresident property owners. For instance, in November 2016, Berkeley, California, decided to lower the voting age to sixteen for its school board elections and San Francisco voters narrowly rejected a referendum to reduce the voting age to sixteen for all of its city elections. ${ }^{3}$ Some small jurisdictions have already lowered the voting age or otherwise expanded the right to vote in local elections for other interested groups, such as noncitizens or nonresident property owners. ${ }^{4}$ These local voting rules are significant in their own right, and they also may foreshadow expanded suffrage in state or federal elections.

Despite this robust activity on the local level, however, most election law scholarship has analyzed the right to vote primarily from the perspective of the U.S. Constitution. ${ }^{5}$ More recently, in the wake of limited protection of voting rights from federal courts, scholars and litigants have considered the power of state constitutions. ${ }^{6}$ Yet elec-

1 The West Wing: A Good Day (NBC television broadcast Mar. 2, 2005).

2 Id.

3 See Aleah Jennings-Newhouse et al., City Measures T1, U1, V1, W1, X1, Y1, Z1, AA Pass; Measures BB, CC, DD Fail, Daily Californian (Nov. 9, 2016), http://www.dailycal.org/ 2016/11/09/city-measures-t1-u1-v1-w1-x1-y1-z1-aa-pass-measures-bb-cc-dd-fail/; Measure Y1City of Berkeley, Alameda County, CA, http://www.acgov.org/rov_app/current_election/ nofrace.jsp? $\mathrm{e}=230 \& \mathrm{f}=124124$.htm (last updated Nov. 18, 2016, 8:11 PM); November 8, 2016 Official Election Results: Local Measure F-Youth Voting in Local Elections, CiTy \& CounTy S.F.: DeP't Elections, http://www.sfelections.org/results/20161108/\#a_english_42 (last updated Dec. 6, 2016, 3:59 PM); see also Emily Green, Supervisors OK Ballot Measure to Lower SF Voting Age to 16, SFGATE (MAy 10, 2016, 9:02 PM), http://www.sfgate.com/politics/article/Supervisors-OKballot-measure-to-lower-SF-voting-7458077.php.

4 See infra Part II.

5 See Joshua A. Douglas, State Judges and the Right to Vote, 77 Oнго Sт. L.J. 1, 11 (2016) (noting that "virtually all recent scholarship on the right to vote has focused either on U.S. Supreme Court cases or has isolated a single state's jurisprudence"); Adam Winkler, Voters' Rights and Parties' Wrongs: Early Political Party Regulation in the State Courts, 1886-1915, 100 Colum. L. Rev. 873, 873 (2000) ("The focus [of election law scholarship] has been on federal law and U.S. Supreme Court decisions, even though each of the fifty states has its own set of detailed election regulations.").

6 See, e.g., Martin v. Kohls, 444 S.W.3d 844, 852 (Ark. 2014) (invalidating voter identification law under the state constitution). See generally Joshua A. Douglas, The Right to Vote Under State Constitutions, 67 VAND. L. REv. 89 (2014) (advocating for the use of state constitutions to provide greater protection to the right to vote); James A. Gardner, Liberty, Community and the Constitutional Structure of Political Influence: A Reconsideration of the Right to Vote, 145 U. PA. 
tion law scholarship has not focused on what is happening on the ground in cities and towns across the country. ${ }^{7}$ This Article fills that void. It details local voting rights laws, providing a fuller examination of the right to vote in America. A complete picture of the right to vote requires at least three levels of inquiry: the U.S. Constitution and federal law, state constitutions and state law, and local laws that confer voting rights for municipal elections. ${ }^{8}$ This Article completes the trilogy. ${ }^{9}$

Local elections-for mayor, city council, school board, and the like-are extremely important and meaningful. ${ }^{10}$ People are closest to their local elected officials. Many voters know their city council member personally; few people are acquaintances with their member of Congress, the Governor, or the President. When individuals have a problem or need something done, they often call their local representative. The outcome of a local race can have a significant impact on the scope of local policy, which often has a much greater effect on

L. REv. 893 (1997) (considering the ability of state constitutions to police partisan gerrymandering); see also generally Michael T. Morley, Rethinking the Right to Vote Under State Constitutions, 67 VAND. L. REV. EN BANC 189 (2014) (arguing against Douglas's proposition that state constitutions provide more protection for local voters than the U.S. Constitution).

7 Indeed, my own scholarship has followed this track: I first wrote an article discussing the federal right to vote before more recently exploring what state constitutions say about the subject. See generally Joshua A. Douglas, Is the Right to Vote Really Fundamental?, 18 Cornell J.L. \& Pub. PoL'y 143 (2008); Douglas, supra note 6.

8 Various procedural rules on the voting process also can affect who may vote. This Article, however, focuses on substantive qualification provisions in local laws and does not discuss separate rules involving election administration.

9 International norms on the right to vote also may implicate how the United States should treat this fundamental right. See, e.g., Gregory H. Fox, The Right to Political Participation in International Law, 17 Yale J. InT'L L. 539, 541 (1992); Alexander Kirshner, Democracy Coalition Project, The International Status of the Right to Vote, http://archive.fairvote.org/media/rtv/ kirshner.pdf (last visited May 27, 2017).

10 See infra Part I. Importantly, this article analyzes the qualification rules for general purpose local elections (which include governmental units that can tax or regulate individuals' primary behavior) and does not consider in detail special-purpose or limited-purpose elections, such as for water districts or the like. The Supreme Court has generally exempted special-purpose districts (besides school boards) from traditional election law rules such as the one person, one vote requirement. See Ball v. James, 451 U.S. 355, 370 (1981); see also Richard Briffault, Who Rules at Home?: One Person/One Vote and Local Governments, 60 U. CHI. L. Rev. 339, 421 (1993) ("These local arrangements were, in effect, depoliticized, and their voting and apportionment rules were held to have no implications for local popular representation in local governance."); Ellen D. Katz, Race and the Right to Vote After Rice v. Cayetano, 99 Mich. L. REv. 491, 508 (2000) ("The Court has applied deferential rational basis review to electoral restrictions in special-purpose districts in past cases only because it has not viewed such restrictions to implicate a fundamental right to vote.”). But see Rice v. Cayetano, 528 U.S. 495, 522 (2000) (suggesting that the Fifteenth Amendment's prohibition against racial classifications in voting would apply to a special-purpose election). 
individuals than statewide or national laws. Participatory democracy and political community flourishes at the local level. In sum, there is a lot at stake in local elections.

Discerning who is part of the local electorate, then, is vital for understanding the operation of local democracy. Yet the electorate in many places differs from the population eligible to vote for state or national races. Municipalities have expanded the right to vote in local elections to sixteen- and seventeen-year-olds, noncitizens, and nonresident property owners. ${ }^{11}$ Local laws also have the potential to enfranchise other groups who cannot vote in state or national elections, such as felons. ${ }^{12}$

On a broader scale, expansions of the right to vote for municipal elections might lead to voting rights reforms at the statewide or national level. Some voting rights developments, such as the elimination of property requirements and the women's suffrage movement, saw early successes for local elections before enjoying more widespread adoption. ${ }^{13}$ If states are "laboratories of democracy" that can try out various reforms, then municipalities can be "test tubes of democracy" that may experiment with different voting rules. ${ }^{14}$ These expansions can then "trickle across" to other municipalities, and eventually "trickle up" to states or Congress, which will more likely adopt reforms that are working well at the local level. Thus, it is important to highlight the first movers on expanded voting rights, as they may serve as catalysts for more widespread changes. Robust protection of the right to vote depends on local voting rules as an early component of the reform effort.

This Article, the first to explore in depth the local right to vote, proceeds in three Parts. Part I provides historical context, showing that in the late 1700 s and early 1800 s, voter eligibility rules for local elections were sometimes more expansive than for state or national elections. Specifically, states and localities eliminated property requirements for voting and allowed women to vote in school board or

11 See infra Part II.

12 See, e.g., TAkoma Park, Md., Mun. Code art. VI, § 601 (2016), http://www.codepub lishing.com/MD/TakomaPark/\#!/takomaparkch/TakomaParkCH06.html\#06 (disenfranchising felons who are currently in prison, but not those who have completed their sentence); Lindsay A. Powers, Takoma Park Grants 16-Year-Olds Right to Vote, WAsh. Post (May 14, 2013), https:/ /www.washingtonpost.com/local/takoma-park-grants-16-year-olds-right-to-vote/2013/05/14/b27c 52c4-bccd-11e2-89c9-3be8095fe767_story.html (noting that Takoma Park extended the right to vote to felons who have completed their sentence).

13 See infra Part I.

14 See infra Section III.B. 
city elections well before these rules applied to state or national elections. These laws were harbingers of the larger movement for expanded voting rights.

Part II then analyzes the current debate on voting rights in cities and towns across the country. Various jurisdictions have enacted ordinances that expand the electorate for local elections. Municipalities have lowered the voting age to sixteen, enfranchised noncitizens, and added nonresident property owners to the voter rolls. Other larger jurisdictions are in the midst of debates about whether to expand the electorate for their own elections.

Part III explores both the policy and law behind local laws enfranchising new groups. Section III.A makes a normative argument in favor of expanding the franchise as a means of enhancing democratic representation and legitimacy. Section III.B argues that, as a policy matter, local jurisdictions are well suited to engage in this voter expansion. Municipalities can be "test tubes of democracy," experimenting with different electoral rules. Although each jurisdiction should decide for itself who should comprise its own local electorate, as a guiding principle local jurisdictions should enfranchise anyone who has a sufficient stake in local affairs and has the proper incentives and ability to make informed choices about who should lead them.

Section III.C explains how to navigate the potential legal hurdles that local voting rules may face. There are no significant U.S. constitutional issues with expanding the right to vote in local elections, but some state constitutions or state laws may preclude differing local laws unless there is a change to the statewide rules. For instance, some states may set the substantive qualifications of voters that must apply to all elections. In other states, municipalities may not have the power of "home rule," or local control. The policy arguments in favor of local democracy and local experimentation should lead these states to reform their state constitutions or state legislation by either eliminating the uniform voter qualification requirements or granting home rule for local elections. An Appendix presents a chart of all fifty states (and D.C.) that lists which states have these potential hurdles.

Stemming from these state-level constitutional or legislative limits, a local voting rule might face judicial review. Section III.C provides a workable test for judges to use when considering these challenges: courts should defer to local rules expanding the right to vote as a means of local democracy but should not defer to municipal laws that restrict the franchise. Finally, Section III.D concludes by discussing the potential logistical problems in administering an election 
with an expanded electorate for some races on the ballot but not others. Voting technology can mitigate these implementation issues.

This Article completes the picture of what it means to enjoy the right to vote in America. The right to vote is a constitutional right inherent in the U.S. Constitution and all state constitutions. But it is also a locally conferred right, at least in some cities and towns. This expansion of voting rights at the local level will constitute a significant part of the debate on the right to vote for years to come.

\section{Localism as a Catalyst for Broader Change in Voting Rights: A Historical Perspective}

Local laws can serve as a springboard to broader reform nationwide, particularly in the expansion of the franchise. History has shown that municipal voting rules provided significant assistance to at least some suffrage movements. Although local election administrators have been complicit in disenfranchising various groups (such as minority voters) through the application of onerous registration laws, poll taxes, literacy tests, or other means, ${ }^{15}$ voting rules for local elections have also been more expansive at times.

Historically, most state and local laws were coterminous, owing to the theory of "Dillon's rule" (named after Judge John Dillon), which held that "state power over municipalities was 'supreme and transcendent,' [and] that municipalities had no 'inherent right of local self-government which is beyond legislative control.'" 16 Yet some states and municipalities were early movers in enacting local-specific rules for voting. ${ }^{17}$ "Although never widespread, distinctive municipal franchise regulations were adopted in Tulsa, Kansas City, Deer Park, Maryland, and Oklahoma City, among other places, and they continued to surface throughout the twentieth century." 18

In particular, the debates regarding both the abolition of property requirements for voting and the women's suffrage movement initially

15 See Nina Perales et al., Voting Rights in Texas: 1982-2006, 17 S. Cal. Rev. L. \& Soc. Just. 713, 714, 721 (2008) (highlighting examples of local officials wrongly disenfranchising voters in Texas). See generally Alexander Keyssar, The Right to Vote: The Contested HisTORy OF Democracy IN THE United States 111-112 (2000) (discussing various methods of disenfranchisement by local officials).

16 Keyssar, supra note 15, at 167; see Hunter v. City of Pittsburgh, 207 U.S. 161, 178 (1907) ("Municipal corporations are political subdivisions of the State, created as convenient agencies for exercising such of the governmental powers of the State as may be entrusted to them."); see also infra Section III.C.

17 KEYSSAR, supra note 15 , at 168 .

18 Id. 
involved laws for local elections. The push for expanding the franchise for local elections likely had an effect on the subsequent reform efforts at the statewide and national level. This fact does not, of course, diminish the significance of the debates statewide and nationally, but it does add another layer to our understanding of the history of voting rights. Local laws can serve as a catalyst for further reforms. The history of property qualifications and women's suffrage thus sheds light on the ongoing efforts to change municipal laws to expand the franchise, such as for young people, noncitizens, and nonresident property owners. ${ }^{19}$

\section{A. Property Requirements}

At the Founding, most states restricted voting only to property owners. ${ }^{20}$ As historian Alexander Keyssar recounts, "The lynchpin of both colonial and British suffrage regulations was the restriction of voting to adult men who owned property." 21 Yet states began to relax these property requirements throughout the first few decades of the country's history, and by the end of the 1850 s property requirements remained only for "foreign-born residents of Rhode Island and . . . African Americans in New York." 22 Professor Keyssar points to three main reasons for the elimination of property ownership requirements for voting: "widespread and significant changes in the social structure and social composition of the nation's population; the appearance or expansion of conditions under which the material interests of the enfranchised could be served by broadening the franchise; and the formation of broadly based political parties that competed systematically for votes." ${ }_{23}$ In essence, the changing demographics and geopolitical landscape of the nation caused several localities to remove property requirements for voting.

19 See infra Part II.

20 See Keyssar, supra note 15, at 5; see, e.g., An Act Concerning Election of Members of General Assembly (1785), reprinted in A Collection of All Such Acts of the General Assembly of Virginia, of a Public and Permanent Nature, as Are Now in Force 19 (Richmond, Samuel Pleasants \& Henry Pace 1803).

21 Keyssar, supra note 15 , at 5.

22 Of the Rights and Qualifications of Voters, reprinted in The ReVised STATUtes of The State of Rhode Island and Providence Plantations 68 (Sayles, Miller \& Simons 1857); An Act Respecting Elections Other Than for Militia and Town Officers, reprinted in Laws of the State of New-York, Passed at the Sixty-Fifth Session of the Legislature, Begun and Held in the City of Albany 109 (Thurlow Weed 1842); Keyssar, supra note 15, at 29; see also Kirk H. Porter, A History of Suffrage in the United States 110-11 (1918).

23 KeYsSAR, supra note 15 , at 34. 
Yet even during this Founding period several municipalities did not have property requirements, despite state laws to the contrary:

The most common manner in which municipal voting rights differed from the state suffrage was in the configuration of property restrictions: increasingly, urban residents who did not own real property could vote if they met either a personal property or a taxpaying requirement. The principles of state law were, in effect, adapted to urban conditions. In some locales, however, the differences were more substantial. Nine of the cities chartered during the revolution granted the franchise to nearly all adult males; and Massachusetts, in the 1780s, passed a series of laws that gave the right to vote in town meetings to all men who could meet a minimal taxpaying requirement. ${ }^{24}$

As Professor Keyssar concludes, "On the whole, municipal voting rights tended to broaden more rapidly than did the right to vote in state elections, probably because of pressure from propertyless urban citizens." 25

This discussion should not diminish the fact that, throughout the nineteenth century, some local voting rules were more restrictive than their state counterparts. ${ }^{26}$ For instance, most former Confederate states adopted property requirements (as well as other methods of voter suppression such as poll taxes) for municipal voters after Reconstruction as a way to disenfranchise newly freed slaves. ${ }^{27}$ Yet earlier in the 1800 s, the push and pull between state and local laws sometimes led state legislatures and municipalities to pass more expansive voting rules for local elections. ${ }^{28}$

Although there may be little hard evidence that municipal-specific rules served as the actual catalyst for statewide or national changes, it is possible that they had an appreciable influence. Several local laws decoupling property ownership and voting were in place well before states began relaxing their own property requirements for voting..$^{29}$ Moreover, the expansion of voting rights occurred in large

24 Id. at $20-21$.

25 Id. at 21; see also Jon C. Teaford, The Municipal Revolution in America: OriGins of Modern Urban Government: 1650-1825, at 66-67 (1975).

26 See Keyssar, supra note 15 , at 30-31.

27 See William Gillette, Retreat From Reconstruction: 1869-1879, at 40-42 (1979).

28 See Keyssar, supra note 15, at 31.

29 See id. at 20-21. It took until 1969 for the U.S. Supreme Court to outlaw property qualifications for local elections, well after many of these local jurisdictions acted themselves to ex- 
part due to the advocacy of the increasing population of propertyless men in urban areas who contributed to the economic and social life of the cities. ${ }^{30}$

The key takeaway is that early rules removing property requirements for voting applied to local elections before becoming more widespread for state and national elections. This historical data point in the evolution of voting rights demonstrates the importance of local laws on the right to vote.

\section{B. Women's Suffrage}

Women earned the right to vote in various local elections, particularly for school boards, well before the Nineteenth Amendment enfranchised women nationwide for all elections in 1920. These early successes for local elections likely helped the nationwide reform effort. Although many of these examples entailed statewide expansions of voting rights for local elections, and not municipal-specific laws, they still demonstrate the greater societal comfort in broadening the electorate for local races before doing so for statewide or federal elections. That is, the provision of voting rights for local elections foreshadowed greater expansions of voting rights nationally.

As early as 1838 , Kentucky women could vote in school board elections. ${ }^{31}$ Similarly, as of 1859, Kansas's constitution allowed women to vote for school board. ${ }^{32}$ The theory behind permitting women to vote in these elections was that children's education was a "maternal" issue..$^{33}$ In 1869, Wyoming became the first territory to allow women to vote in all elections, making it the first state to grant women's suffrage when it entered the Union in $1890 .^{34}$ In 1887 , Kansas gave women the right to vote in municipal elections. ${ }^{35}$ Women's suffrage in all elections

pand the franchise. See Kramer v. Union Free Sch. Dist. No. 15, 395 U.S. 621, 632-33 (1969); Cipriano v. City of Houma, 395 U.S. 701, 706 (1969).

30 See Keyssar, supra note 15, at 35.

31 Id. at 175 .

32 Eunice Chwenyen Peters, There's No Place Like Home, J. Kan. B. Ass's, Feb. 2011, at $14,14$.

33 See J. Morgan Kousser, Voting Rights, in Oxford Handbook of American PolitiCAl History (Oxford Univ. Press forthcoming) (on file with author).

34 Sandra Day O'Connor, The History of the Women's Suffrage Movement, 49 VAnd. L. Rev. 657, 662-63 (1996). New Jersey's constitution of 1776 and a state statute of 1790 actually included women as qualified voters, but the state then repealed the right to vote for women in 1807. Keyssar, supra note 15, at 54. Justice O'Connor pointed to the Wyoming example as a benefit of federalism, as early state adoption of women's suffrage eventually culminated in the Nineteenth Amendment. See FERC v. Mississippi, 456 U.S. 742, 788 (1982) (O'Connor, J., concurring in the judgment in part and dissenting in part).

35 Peters, supra note 32, at 14. 
in Kansas followed suit in 1912, eight years before the ratification of the Nineteenth Amendment. ${ }^{36}$

Courts generally upheld these early local expansions of the right to vote. ${ }^{37}$ For instance, plaintiffs challenged an East Cleveland, Ohio, charter that granted women the right to vote in city elections..$^{38}$ The state constitution conferred voting rights only to "[e]very white male citizen." ${ }^{39}$ In 1917-before the ratification of the Nineteenth Amendment - the Ohio Supreme Court held that the constitutional rule applied only to elections for offices created by the state constitution, not to local elections..$^{40}$ Municipalities could expand the right to vote for their local elections beyond what the state constitution conferred. ${ }^{41}$ The court cited an 1889 case from the Michigan Supreme Court that affirmed the City of Flint's decision to allow women to vote in school board elections. ${ }^{42}$ Similarly, the Wisconsin Supreme Court held in 1887 that a state rule allowing women to vote in "any election pertaining to school matters" applied broadly to any election of "officials whose actions had a direct or indirect affect [sic] on the schools." 43 The Supreme Court of Illinois ruled the same way in $1893,{ }^{44}$ as did the Supreme Court of North Dakota in 1918.45

But not all courts were in agreement. The Massachusetts Supreme Judicial Court, in an advisory opinion in 1894, found that requiring the "people" of the state to approve a law granting women the right to vote in local elections violated the state constitution. ${ }^{46}$ In a separate dissenting statement, Justice Oliver Wendell Holmes explained that he found "nothing which forbids the legislature to establish a local option upon this point." ${ }^{77}$ In 1917, the Supreme Court of

36 Id.

37 See Current Decisions, Constitutional Law-Qualifications of Voters-Woman Suffrage in City Elections, 27 YALE L.J. 421, 421 (1918).

38 See State ex rel. Taylor v. French, 117 N.E. 173 (Ohio 1917).

39 Id. at 174 (quoting Онго Const. art. V, § 1).

40 See id. at 176.

41 See id.

42 Belles v. Burr, 43 N.W. 24, 27 (Mich. 1889) (noting that "the qualifications of voters for school officers, or upon questions arising at school meetings, have never been identical with those of electors, as defined in the constitution").

43 Joseph A. Ranney, Wisconsin Law in the Age of Institutions: Chief Justices Winslow and Rosenberry, Wis. Law., Feb. 1995, at 22, 23.

44 Plummer v. Yost, 33 N.E. 191, 194 (Ill. 1893).

45 Spatgen v. O'Neil, 169 N.W. 491, 494 (N.D. 1918) ("We are satisfied that the Legislature, in the exercise of its control over minor municipalities, may authorize women to participate in the selection of local officers whose election is not provided for in the Constitution.").

46 In re Mun. Suffrage to Women, 36 N.E. 488, 490 (Mass. 1894).

47 Id. at 492 (Holmes, J., dissenting). 
Indiana invalidated a state law enfranchising women in local elections. ${ }^{48}$ Underlying these decisions, of course, was the reality that Massachusetts and Indiana were debating voting rights for women in local elections well before the ratification of the Nineteenth Amendment granted the right to vote to women for all elections. Allowing women to vote in local elections initially was more acceptable than enfranchising them outright.

These examples show that women could vote in various municipal elections prior to the Nineteenth Amendment, whether through local rules or statewide grants. Although the women's suffrage movement was initially unsuccessful at the federal and statewide level, several "partial" expansions of suffrage for women existed for local elections, such as for school boards. ${ }^{49}$ As Professor Keyssar explains:

There were . . . a significant number of locales-states, counties, and municipalities-where partial suffrage was adopted, permitting women to vote in municipal elections, on liquor licensing matters, or for local school boards and on issues affecting education. This unique, even anomalous development-enabling women to vote in certain elections but not in others-was made possible by the complex architecture of voting laws. In most states, the suffrage requirements for "nonconstitutional" elections did not have to be identical to those for offices named in state constitutions; they also could be altered by legislation rather than the cumbersome and difficult process of constitutional amendment. ${ }^{50}$

Indeed, by 1890 , over twenty states had enacted laws granting women the right to vote in school elections. ${ }^{51}$ These rules largely came about through state legislation, passed after voters rejected similar referenda in some states, showing that the legislatures "appeared to be more progressive than the voters." 52 The pro-suffrage activists considered this success "a stepping-stone, an entering wedge for broader electoral participation." ${ }_{53}$ By contrast, some legislators supported

48 Bd. of Election Comm'rs v. Knight, 117 N.E. 565, 571 (Ind. 1917).

49 KeysSAR, supra note 15 , at 185-87.

50 Id. at 186 (citation omitted).

51 Id.

52 Nathaniel Persily \& Melissa Cully Anderson, Regulating Democracy Through Democracy: The Use of Direct Legislation in Election Law Reform, 78 S. CAL. L. Rev. 997, 1028-29 (2005) ("For example, suffrage advocates in Oregon, one of the first adopters of direct legislation (1902), fought perhaps the most trying campaigns for the vote. Although Oregon was an early adopter of equal suffrage in 1912, it was only after five previous defeats in 1884, 1900, 1906, 1908, and 1910.").

53 KeysSAR, supra note 15 , at 186. 
granting the right to vote only in school elections simply to placate reformers and avoid broader voter expansions..$^{54}$

In surveying the push for women's suffrage, Professor Morgan Kousser notes how the battle was fought at many levels, including through local advocacy: "to gain the right to vote, advocates would already have to exercise political power at every level from the tiniest hamlet and precinct to the floor of Congress." 55 Early victories in municipalities around the country likely paved the way for broader, nationwide reform through statewide efforts and, ultimately, the Nineteenth Amendment.

Of course, not all expansions of voting rights have come about through local laws. The history of racial minority voting, for instance, shows how local jurisdictions often denied the right to vote to minorities, with federal law serving as the stopgap to overrule these practices. ${ }^{56}$ Congress was instrumental in ending some of the worst abuses of local officials denying the franchise to African Americans by enacting the Voting Rights Act of $1965 .{ }^{57}$ Yet this traditional narrative of federal law mandating voter enfranchisement overlooks significant instances in which localities led the way in expanding the franchise to various populations. The fact that some movements, targeted specifically at expanding suffrage, had a significant local component provides an important lesson for the right to vote moving forward: local voting rules can serve as a catalyst for broad-reaching reforms. If we want to make voting easier, more accessible, and more universal, we should focus on the local level.

54 Id.

55 Kousser, supra note 33 (manuscript at 17).

56 See Keyssar, supra note 15, at 256-63. The history of the retraction and expansion of minority voting rights is quite complex. Several state constitutions initially allowed African Americans to vote, but between 1790 and 1850 many states revised their laws to exclude blacks from voting. See id. at 54-56. Yet blacks could sometimes vote in local elections that affected their interests. For instance, African Americans successfully resecured their right to vote in Providence, Rhode Island, in 1843 when the state enacted a new constitution. See id. at 57; MANISHA Sinha, The Slave's Cause: A History of Abolition 322 (2016). Similarly, in the 1850s, Cincinnati allowed African Americans to vote in school director elections for "colored" schools. See State ex rel. Dirs. of the E. \& W. Sch. Dists. v. City of Cincinnati, 19 Ohio 178, 197-98 (1850) (upholding law allowing "colored voters" to elect the school director of a "colored" school). The Cincinnati example is interesting because it shows how a local law provided more expansive voting rights for racial minorities than the state constitution permitted, albeit while promoting segregation.

57 See Voting Rights Act of 1965, Pub. L. No. 89-110, 79 Stat. 437 (codified as amended in scattered sections of 52 U.S.C.). See generally Ari Berman, Give Us the Ballot: The Modern Struggle for Voting Rights in America (2015) (documenting the history of the civil rights movement and the push for minority voting rights). 


\section{Modern Local Voting Reform}

In recent years, municipalities across the country have enacted, or at least debated, local ordinances regarding the right to vote. Cities and towns have lowered the voting age in local elections to sixteen, granted the right to vote to noncitizens, expanded access for propertyowning nonresidents, and called for greater overall inclusion for those otherwise disenfranchised, such as felons. This Part examines these ordinances to highlight the grassroots nature of voting rights reform and demonstrates that localism should be an important consideration for anyone concerned about protecting the constitutional right to vote.

\section{A. Lowering the Voting Age}

In 2013, the city of Takoma Park, Maryland-a suburb of Washington, D.C.- passed a charter amendment lowering the voting age for city elections to sixteen. ${ }^{58}$ Section 601 (a) of that governing document now reads:

Every person who (1) is a resident of the City of Takoma Park, (2) is at least sixteen (16) years of age or will be sixteen (16) years of age on or before the date of the next City election, (3) has resided within the corporate limits of the City for 21 days immediately preceding the City election, (4) does not claim voting residence or the right to vote in another jurisdiction, and (5) is registered to vote in accordance with the provisions of this charter, is a qualified voter of the City except as provided in subsection (b) of this section. ${ }^{59}$

Subsection (b) then denies voting rights to felons serving a prison sentence, those who have been judged mentally disabled, and anyone convicted of vote buying. ${ }^{60}$ Lowering the voting age expanded the voter rolls in Takoma Park by about 350 people. ${ }^{61}$ Council Member Tim Male sponsored the ordinance as a way to increase citizen participation in local elections. ${ }^{62}$ In crafting the law, Male took the advice of Rob Richie, the director of a national organization called FairVote,

58 Powers, supra note 12.

59 TAKoma Park, Md., Mun. Code art. VI, § 601(a) (2016), http://www.codepublishing. com/MD/TakomaPark/\#!/takomaparkch/TakomaParkCH06.html\#06.

60 Id. $\S 601(\mathrm{~b})$.

61 See Annys Shin, Takoma Park 16-Year-Old Savors His History-Making Moment at the Polls, WAsh. Post (Nov. 3, 2013), https://www.washingtonpost.com/local/takoma-park-16-yearold-savors-his-history-making-moment-at-the-polls/2013/11/03/89f00962-425c-11e3-b028-de922d 7a3f47_story.html.

62 See id. 
who thought of the idea when he read a report from Denmark saying that younger teenagers were more likely to vote than older teens. ${ }^{63}$

The movement in Takoma Park began with a municipal Right to Vote Resolution. ${ }^{64}$ That resolution noted that

local governments like ours have the power to enact laws and procedures for local elections that meet or surpass federal and state election standards, that create more accountable representation, that uphold voting rights, that encourage increased voter participation, and that promote greater awareness of our political process through civic education. ${ }^{65}$

The resolution then affirmed that the right to vote is a fundamental right, established a Task Force on Voting, and called on federal and state officeholders to take actions that will protect voting rights. ${ }^{66} \mathrm{On}$ expanding voting opportunities, the resolution specifically directed the Task Force to "[r]ecommend actions by the City before the 2013 elections to promote new suffrage opportunities and other participation in City government for and by residents who have turned 16, same-day voter registration and residents who are currently on parole or probation as a result of a felony conviction." ${ }^{77}$ The Task Force's recommendations led to the ordinance that, among other things, lowered the voting age in Takoma Park.

Takoma Park's initial experience with lowering the voting agealbeit a sample of one town with a small population-is instructive. In the November 2013 election, which included an incumbent mayor with only a write-in challenger and no contested city council elections, $44 \%$ of the newly enfranchised and registered sixteen- and seventeenyear-olds went to the polls, as compared to an overall turnout rate of 11\%. ${ }^{68}$ Similarly, in Takoma Park's 2014 election, 134 individuals aged sixteen or seventeen registered to vote, and about half of them showed up, far exceeding the $10 \%$ turnout rate among the rest of the city's voters. ${ }^{69}$ Although the raw numbers for this one city are small,

63 See id. I am a member of the "Leadership Circle" for a FairVote initiative called "Promote Our Vote." See Leadership, Prомоте Our Vote, http://www.promoteourvote.com/leader ship.html [https://perma.cc/5BHG-6FHJ] (last visited May 28, 2017).

64 City of Takoma Park, Md., Res. 2013-25 (May 13, 2013), http://www.promoteour vote.com/uploads/9/2/2/7/9227685/takoma_park_right_to_vote_resolution.pdf.

65 Id.

$66 I d$.

67 Id.

68 See J.B. Wogan, Takoma Park Sees High Turnout Among Teens After Election Reform, Governing (Nov. 7, 2013), http://www.governing.com/news/headlines/gov-maryland-city-seeshigh-turnout-among-teens-after-election-reform.html.

69 Elena Schneider, Students in Maryland Test Civic Participation and Win Right to Vote, 
and the novelty of gaining voting rights could wear off in subsequent elections, the potential is huge if extrapolated to a larger metropolis. Turnout among eighteen- to twenty-four-year-olds nationwide is the lowest among all age groups, ${ }^{70}$ but that trend is reversible if sixteenand seventeen-year-olds begin a habit of voting earlier in their lives when they are not also dealing with moving, entering the workforce, or beginning college. Assuming that younger voters turn out in sufficient numbers, they could impact who is elected and the policies that affect them. Takoma Park showed that this reform is achievable city by city throughout the country.

Hyattsville, Maryland, was the next locality to heed this message..$^{71}$ In January 2015, the Hyattsville City Council voted to lower the voting age for town elections to sixteen. ${ }^{72}$ In the next election, newly registered sixteen- and seventeen-year-olds voted at a rate of $25 \%$, helping the town exceed its turnout goal. ${ }^{73}$

These successes in two small Maryland towns have been harbingers of the reform movement in larger cities. ${ }^{74}$ Berkeley, California, recently lowered the voting age to sixteen for its school board elections. ${ }^{75}$ In San Francisco, members of the San Francisco Youth Commission have been advocating for the city to lower the voting age for municipal and school district elections. ${ }^{76}$ Although the measure passed the City's Board of Supervisors, a referendum on the issue failed by a

N.Y. Times (Jan. 9, 2015), http://www.nytimes.com/2015/01/10/us/politics/students-in-marylandtest-civic-participation-and-win-right-to-vote.html.

70 See Thom File, U.S. Census Bureau, Young-Adult Voting: An Analysis of Presidential Elections, 1964-2012, at 2 (2014), https://www.census.gov/prod/2014pubs/p20573.pdf.

71 See Schneider, supra note 69.

72 Id; see Hyattsville, Md., Charter \& Code art. IV, § C4-1 (2015), http:// www.hyattsville.org/DocumentCenter/Home/View/340 ("Every person who is a citizen of the United States, is at least sixteen (16) years of age, resides in the State of Maryland, resides within the corporate limits of the City and is registered in accordance with the provisions of this Charter shall be a qualified voter of the City. Every qualified voter of the City shall be entitled to vote at any or all City elections.").

73 See Rebecca Bennett, Ward and Warner Election Winners; City Exceeds Voter Turnout Goal, Hyattsville Life \& Times (May 12, 2015, 6:12 PM), http:/hyattsvillelife.com/ward-andwarner-election-winners-city-exceeds-voter-turnout-goal/.

74 In addition to lowering the voting age in municipal elections, many states allow seventeen-year-olds to vote in party primaries if they will be eighteen by Election Day. See Voting in Primaries at 17 Years Old, BALlotPEDIA, https://ballotpedia.org/Voting_in_primaries_at _17_years_old [https://perma.cc/V57X-Z7ZC] (last visited May 28, 2017).

75 Jennings-Newhouse, supra note 3.

76 See Laura Dudnick, Youths Seek to Lower Voting Age to 16 in SF, S.F. Examiner (Jan. 6, 2015), http://archives.sfexaminer.com/sanfrancisco/youths-seek-to-lower-voting-age-to-16-insf/Content?oid=2916012; Green, supra note 3. 
$52 \%-48 \%$ margin in $2016 . .^{77}$ Given this close outcome, advocates plan to put the question on the ballot again in $2020 .{ }^{78}$ Reformers are also working to petition the Chicago City Council to consider this change. ${ }^{79}$

Similarly, Washington, D.C., has debated whether to pass an ordinance allowing sixteen- and seventeen-year-olds to vote in presidential and local elections. ${ }^{80}$ Advocates note that the city's lawmakers "barely listen[ed] to the District's youths amid a spike in violence" during the summer of 2015 and that lowering the voting age would give younger individuals more political power. ${ }^{81}$ The D.C. proposal goes further than the Maryland or California examples because it lowers the voting age not just for city elections but for the presidential election as well. As one proponent explains, "It's not just about having young people vote .... It's about creating a new generation of lifelong voters." $\$ 2$

Meanwhile, advocates in Lowell, Massachusetts, who under Massachusetts law must secure the state legislature's approval to lower the voting age in municipal elections,$^{83}$ won the support of the State Senate in 2013 but have not yet convinced the State House. ${ }^{84}$ Legislators in New Mexico and youth council members in Richmond, California, are planning to introduce bills to lower the voting age for city elec-

77 See Press Release, Vote16USA, Historic Measure Almost Passes: More than 172,000 Vote to Extend Voting Rights to 16-Year-Olds for Municipal Elections (Nov. 28, 2016), http:// vote16usa.org/press-release-historic-measure-almost-passes-more-than-172000-vote-to-extendvoting-rights-to-16-year-olds-for-municipal-elections/.

78 See id.

79 See Lower the Voting Age in Chicago, Change.org, https://www.change.org/p/chicagocity-council-lower-the-voting-age-in-chicago-7eb9e713-a4f1-470f-812d-6c09f97492bf [https:// perma.cc/HX6Z-EYER] (last visited Mar. 26, 2017).

80 See Youth Vote Amendment Act of 2015, D.C. Council B21-0468 (2015), http:// lims.dccouncil.us/Download/34820/B21-0468-Introduction.pdf.

81 See Aaron C. Davis, 16-Year-Olds in D.C. Could Vote for President in 2016, Under Proposal, WAsH. Post (Nov. 3, 2015), https://www.washingtonpost.com/local/dc-politics/16-yearolds-in-dc-could-vote-for-president-in-2016-under-proposal/2015/11/03/3175fede-825d-11e5-8ba6 -cec48b74b2a7_story.html.

82 See Patrick Madden, Unlikely Advocates Push to Give 16-Year-Olds A Vote-and a Voice, NPR (Jan. 18, 2016, 3:54 PM), http://www.npr.org/2016/01/18/463489043/unlikely-advo cates-push-to-give-16-year-olds-a-vote-and-a-voice.

83 See infra Section III.C.2.

84 Schneider, supra note 69 . The movement to lower the voting age is not occurring solely at the local level, at least internationally. In 2014, Scotland allowed sixteen- and seventeen-yearolds to vote in the independence referendum on whether to remain part of the United Kingdom, and in 2015, it granted the right to vote to sixteen- and seventeen-year-olds for all elections. See Helen Whitehouse, 16 and 17 Year Olds Granted the Vote in All Scottish Elections, Mirror (UK) (June 19, 2015, 1:57 PM), http://www.mirror.co.uk/news/uk-news/16-17-year-olds-granted5911671. 
tions or at least school board elections. ${ }^{85}$ The movement also has gained the support of advocacy groups, such as Generation Citizen, a nonpartisan organization that focuses on youth participation in politics and has begun an initiative called Vote16USA. ${ }^{86}$

At least one jurisdiction has lowered the voting age even below sixteen for certain special elections. In Cambridge, Massachusetts, anyone aged twelve or older may vote in the city's "Participatory Budgeting" election. ${ }^{87}$ This election directs the city on how to use some of its capital budget by allowing voters to select which projects to fund. ${ }^{88}$

The first Participatory Budgeting election in Cambridge demonstrated how expanding the right to vote inherently includes more people in the process, making them feel they have a stake in their community. A survey of voters showed that $2 \%$ were aged twelve to eighteen, while $15 \%$ of respondents were born outside of the United States (although it is not clear from the survey data how many of these individuals are noncitizens).$^{89}$ Although the numbers are small, the expansive voting rights provided a meaningful voice for these individuals. As one voter explained, "As a permanent resident in the U.S. who otherwise has no political say, I'm delighted to have been able to participate in this budgeting process." ${ }^{\circ 0}$ Further, many voters "praised the exposure for teenagers in the community." Similarly, New York City uses Participatory Budgeting to decide how to allocate some of its tax funds, and anyone aged fourteen and older may vote; in the 2014-15

85 See Yamiche Alcindor, Campaign to Lower Voting Age to 16 in Local Races Ignites a Debate, N.Y. Times (Dec. 9, 2015), http://www.nytimes.com/2015/12/10/us/politics/campaign-tolower-voting-age-to-16-in-local-races-ignites-a-debate.html.

86 See id:; see also Generation Citizen, Young Voices at the Ballot Box: Advancing Efforts to Lower the Voting Age, http:/generationcitizen.org/wp-content/uploads/2016/03/GC-VotingAge-Paper-2015-12-07-11.pdf [https://perma.cc/ER52-6243] (last visited May 28, 2017). I am a member of the Vote16USA Advisory Board.

87 FAQs, City of Cambridge Participatory Budgeting, http://pb.cambridgema.gov/ faqs [https://perma.cc/ZX5G-6YYY] (last visited May 28, 2017).

88 Id.

89 Nada Zohdy, Evaluating the Inaugural Participatory Budgeting Process in THE CiTy OF CAMBRidge (2014-2015) 27, 28 (2015), https://d3n8a8pro7vhmx.cloudfront.net/cam bridgema/pages/181/attachments/original/1439245835/Evaluating_the_Inaugural_PB_process_in _Cambridge_-_FINAL_with_ballot.pdf?1439245835. The number of actual young voters was likely higher, as the report lists only the number of people who responded to the post-election survey.

$90 \quad$ Id. at 29.

91 Id. at 33. 
budgeting cycle, voters under eighteen years old comprised approximately $12 \%$ of the electorate. ${ }^{92}$

Strong policy arguments favor lowering the voting age. ${ }^{93}$ First, turning sixteen has "special significance" in our society, as that is when most states allow individuals to obtain driver's licenses and have part-time jobs, and require them to pay taxes on their wages. ${ }^{94} \mathrm{Next}$, the National Youth Rights Association highlights the fairness aspect of lowering the voting age: prosecutors may charge adolescents as adults if they commit crimes, but younger individuals may not participate in our democracy in a more positive way through voting. ${ }^{95}$ Additionally, turning eighteen (the current voting age in most places) is a volatile time in people's lives, when they are leaving home for the workforce or college and are often mobile; sixteen-year-olds, by contrast, are more rooted in their current community, uniquely knowledgeable about local issues, and just as intellectually competent as an eighteen-year-old to select their leaders. ${ }^{96}$ Finally, studies show the potential for a "trickle up" effect: the younger a person begins to vote, the more likely they will sustain that habit throughout their lives. ${ }^{97}$

92 New York City Council, Participatory Budgeting Rulebook 8, http://labs.council.nyc/wpcontent/uploads/2016/05/PBNYC-2016_2017-Rulebook.pdf (last visited May 28, 2017); Urban Justice Center, A People's Budget: A Research and Evaluation Report on Participatory Budgeting in New York City 5, https://cdp.urbanjustice.org/sites/default/files/CDP.WEB.doc_Report_ PBNYC_cycle4findings_20151021.pdf (last visited May 28, 2017); see Colin O'Connor, Participatory Budgeting Grows in NYC-Why Isn't Every Council Member Doing It?, Gотнам GAZETTE (Oct. 23, 2015), http://www.gothamgazette.com/government/5946-participatory-budget ing-grows-in-nyc-why-isnt-every-council-member-doing-it ("Nearly 60 percent of PB voters identified as people of color; approximately one in ten were under 18; nearly 30 percent reported an annual household income of $\$ 25,000$ or below; more than a quarter were born outside of the U.S.; nearly a quarter reported a barrier to voting in regular elections, with one in ten reporting they were not U.S. citizens; and 63 percent identified as female."); Participatory Budgeting, NEw York City Council, http://pbnyc.org/ (last visited May 28, 2017).

93 See generally Joshua A. Douglas, In Defense of Lowering the Voting Age, 165 U. PA. L. Rev. OnLINE 63 (2017), http://www.pennlawreview.com/online/165-U-Pa-L-Rev-Online-63.pdf.

94 See Lower the Voting Age, FAIRVote, http://www.fairvote.org/reforms/right-to-voteamendment/lowering-the-voting-age/ (last visited Mar. 26, 2017). Although choosing any age might seem arbitrary, sixteen makes the most sense given that our society imposes various adultlike obligations at that age, such as obeying the driving laws and paying taxes on part-time wages. Psychological studies also support sixteen as the appropriate age to begin voting. See infra notes 100-05 and accompanying text.

95 See Top Ten Reasons to Lower the Voting Age, Nat'L Youth RTs. Ass'N, http:// youthrights.org/issues/voting-age/top-ten-reasons-to-lower-the-voting-age/ (last visited May 28, 2017).

96 Id.

97 See, e.g., Yosef Bhatti \& Kasper M. Hansen, Leaving the Nest and the Social Act of Voting: Turnout Among First-Time Voters, 22 J. Elections Pub. Opinion \& Parties 380, 397 
Lowering the voting age would also help to achieve greater fairness in political representation. Young adults are underrepresented: they comprise a significant share of the population but have no political power until they are eighteen years old. As Professor Jane Rutherford has explained:

Currently, children are vastly underrepresented politically. Although they are counted for the purpose of determining the number of representatives and constitute twentysix percent of an average congressional district, they cannot vote, nor can anyone else vote on their behalf. In this sense, they share the plight of women before the adoption of the Nineteenth Amendment. Their numbers swell the political power of their communities, but that political power is not shared by them. ${ }^{98}$

Indeed, the U.S. Supreme Court recently explained that current nonvoters still have a stake in their representative democracy, meaning that states can continue to count them to apportion representatives and need not include just voters to delineate districts: "Nonvoters have an important stake in many policy debates-children, their parents, even their grandparents, for example, have a stake in a strong public-education system-and in receiving constituent services, such as help navigating public-benefits bureaucracies." 99 The same logic applies to grant these constituencies a voice in who represents them.

Sixteen-year-olds are mature enough-or at least as mature as individuals aged eighteen or older-to inform themselves sufficiently and make rational voting decisions. Professor Vivian E. Hamilton surveyed various fields, such as behavioral and developmental psychology and social and cognitive neuroscience, to show that individuals

(2012), http://www.promoteourvote.com/uploads/9/2/2/7/9227685/leaving_the_nest_and_the_so cial_act_of_voting.pdf; see also Lower the Voting Age, supra note 94.

98 Jane Rutherford, One Child, One Vote: Proxies for Parents, 82 Minn. L. Rev. 1463, 1465 (1998) (footnote omitted) (advocating not to lower the voting age but instead to give a child's representative a proxy vote to increase children's political influence); see also Annette R. Appell, The Child Question, 2013 Мich. ST. L. REv. 1137, 1172-73 (“Children's suffrage advocates note that the franchise would promote children's unique interests, provide civic educational benefits for children, and create opportunities for parental involvement and assistance in effecting children's right to vote. Indeed, in a country that spends at best $2.2 \%$ of its gross domestic product and less than $10 \%$ of the federal budget on children, children's political power and authority could lead to a larger share of the pie." (footnotes omitted)); Aoife Daly, Demonstrating Positive Obligations: Children's Rights and Peaceful Protest in International Law, 45 Geo. WASH. Int'L L. Rev. 763, 770 (2013) ("Children consistently express that they wish to have greater participation in political matters ....").

99 Evenwel v. Abbott, 136 S. Ct. 1120, 1132 (2016). 
reach an adult-like capacity to make competent decisions such as voting by age sixteen. ${ }^{100}$ The studies conclude that the ability of young individuals to engage in well-informed and rational decisionmaking is highly context-specific: "adolescents reliably reach adultlike cognitiveprocessing capacities by ages fifteen or sixteen, but ... numerous factors (e.g., situations involving high levels of emotion or stress, peer pressure, or time pressure) will predictably compromise their cognitive performance." 101 Voting, however, is not a situation that typically entails unusual emotion, stress, or even peer pressure (given the secret ballot). ${ }^{102}$ Voting instead requires civic engagement and knowledge. In a study using national survey data, researchers found that sixteen- and seventeen-year-olds scored about the same as adults on measures of political tolerance, skill, efficacy, and interest:

[C]ivic knowledge increases between ages 14 and 16 and then changes relatively little thereafter, although, 18-year-olds might be slightly higher in civic knowledge than are 16-yearolds. Most important . . ., 16-year-olds apparently know as much about the American political system as do many young adults; indeed, the average score for 16-year-olds is higher than the averages for civic knowledge for 19-, 21-, and 23year-olds, all of whom are entitled to vote. ${ }^{103}$

The study concludes that "[b]ased on . . . developmental trajectories . . ., there is little empirical reason to award the vote to 18 -yearolds but to deny it to 16-year-olds." 104 In another study of around one thousand adolescents, researchers found that "scores [of cognitive ability] increased between ages 11 and 16 and then leveled off, with no improvement after this age." 105

100 Vivian E. Hamilton, Democratic Inclusion, Cognitive Development, and the Age of Electoral Majority, 77 Brook. L. Rev. 1447 (2012).

101 Id. at 1452; see also id. at 1449 (noting that "by midadolescence, when making unpressured, considered decisions-like those required to privately cast a ballot in an election that has unfolded over time-their cognitive competencies are mature").

102 Id. at 1511-12 ("Elections unfold over a period of time, giving voters the opportunity to deliberate and evaluate options without undue pressure. Many sources of information are readily available over a period of time as well, which voters can use as a kind of scaffolding or heuristics to help them evaluate their choices-broadcast debates, endorsements of candidates, party affiliations, etc. Voting itself is done anonymously and in private, which diminishes the concern that adolescents' choices will be unduly pressured or influenced by peers.").

103 Daniel Hart \& Robert Atkins, American Sixteen- and Seventeen-Year-Olds Are Ready to Vote, 633 Annals Am. Acad. Pol. \& Soc. Sci. 201, 207-08 (2011).

104 Id. at 213.

105 Laurence Steinberg et al., Are Adolescents Less Mature than Adults?: Minors' Access to Abortion, the Juvenile Death Penalty, and the Alleged APA "Flip-Flop," 64 Ам. Psychologist 
Assuming that governments are legitimate only if all competent stakeholders can participate in the selection of the leaders, then democracy requires expanding the right to vote to sixteen- and seventeen-year-olds, as these individuals have reached a sufficient cognitive level for electoral competence. ${ }^{106}$ The studies also show that setting the age at sixteen is not arbitrary and is not a slippery slope to giving the right to vote to even younger children. Adolescents gain the cognitive capacity to begin civic participation by at least age sixteen, but the psychological studies do not support lowering the voting age to individuals younger than sixteen. ${ }^{107}$

To those who think that sixteen-year-olds are too impulsive or immature to vote, or that their brains are not yet fully developed, psychologists note that there is a variation in cognitive capacity depending on the tasks adolescents are completing. ${ }^{108}$ Sixteen-year-olds may not be as developed as older individuals to avoid impulsive, rash judgments, but they are just as competent to make reasoned decisions like voting. As one psychology professor explains:

Adolescents' judgment in situations that permit measured decision-making and consultation with others-what psychologists call "cold cognition"-is just as mature as that of adults by $16 . .$. .

. . Cold cognition is relevant to matters such as voting .... Adolescents can gather evidence, consult with others and take time before making a decision. Adolescents may

583, 592 (2009) (arguing for greater allowance for sixteen-year-olds to make their own health care decisions).

106 See Hamilton, supra note 100, at 1479 (advocating for a "democratic principle of presumptive inclusion"); infra notes 109-11 and accompanying text.

107 See Hart \& Atkins, supra note 103, at 201 ("We also indicate that the developmental evidence suggests that those younger than 16 years of age should be excluded from the electorate."); id. at 210 ("Fourteen-year-olds receive lower scores for political skill than every age between ages 19 and 30; in contrast, the average for 16-year-olds is the same as, or higher than, that of six ages between ages 19 and 30.").

108 See id. at 220 ("While it is likely true that adolescents' capacities to restrain impulsive, emotional behavior may be reduced relative to that of adults, and their life experiences are relatively circumscribed, these capacities do not figure prominently in citizenship and particularly in voting. Neither the sense of membership, the concern with rights, nor the ability to participate in the community rests heavily upon the ability to resist emotional, impulsive actions. Citizenship and voting in the electoral process require, for the most part, decisions made over long periods of time, which allows for deliberation and discussion with others. To date, there is no neurological evidence that indicates that 16 - and 17 -year-olds lack the requisite neurological maturation necessary for citizenship or for responsible voting; nor is there evidence to indicate that a breadth of life experience is necessary for effective citizenship."). 
make bad choices, but statistically speaking, they won't make them any more often than adults. ${ }^{109}$

Even if sixteen- and seventeen-year-olds are mature enough to vote, some may argue that their parents will place an undue influence on them, in essence giving the parents a second vote through their children. But the evidence refutes this objection. Leading up to the Scottish Independence vote in September 2014, a research study found that children aged sixteen and seventeen would not just copy their parents; just under half of them had opposing views and planned to vote differently from their parents. ${ }^{110}$ Advocates for lowering the voting age also note that "undue influence" of husbands was an argument against women's suffrage, and yet wives obviously do not always follow their husbands at the ballot box. ${ }^{111}$

Interesting doctrinal questions may arise when jurisdictions permit those under eighteen to vote, especially if their parents, for whatever reason, refuse to allow them to participate. Which is more important: the minors' right to vote, or the parents' right to direct the upbringing of their children? Does the locally enacted right to vote trump the constitutional rights of parents? Although courts have not yet faced this question, there is a strong argument for the right of adolescents to vote to win out if the issue ever arises. Voting, after all, is a fundamental right. It provides the foundation of our democracy. Children are part of and affected by that democracy. Although parents have a constitutional right to direct the upbringing and education of their children, ${ }^{112}$ the right to vote is more important because it is "preservative of other basic civil and political rights." 113 Allowing youth to vote is preservative of youth rights in our democracy. In essence, voting is paramount because of its importance to democratic legitimacy.

109 Laurence Steinberg, A 16-Year-Old Is As Good as an 18-Year-Old-or a 40-Year-Oldat Voting, L.A. Times (Nov. 3, 2014, 5:15 PM), http://www.latimes.com/opinion/op-ed/la-oesteinberg-lower-voting-age-20141104-story.html; see also Joshua Gans, Why It's Time to Give Children the Right to Vote, Forbes (Apr. 20, 2012, 5:17 PM), http://www.forbes.com/sites/joshuagans/2012/04/20/its-time-to-give-children-the-vote/.

110 See Emma Langman, Scottish Independence: Research Finds Young Voters 'Don't Copy Parents,' BBC News (Mar 4, 2014), http://www.bbc.com/news/uk-scotland-scotland-politics26265299; see also JAN EichHorn, ScotCen Soc. Research, Will 16 and 17 Year Olds MAKe a Difference in the Referendum? 12 (2013), http://www.scotcen.org.uk/media/205540 /131129_will-16-and-17-years-olds-make-a-difference.pdf ("Overall, just 56\% of young people propose to vote the same way as the parents who gave permission for them to be interviewed.").

111 See Carrie Kirby, The Case for Letting Teens Vote in Local Elections, CityLab (Oct. 6, 2015), http://www.citylab.com/politics/2015/10/the-case-for-letting-teens-vote-in-local-elections/ 408853/.

112 See Pierce v. Soc'y of Sisters, 268 U.S. 510, 534-35 (1925).

113 Reynolds v. Sims, 377 U.S. 533, 561-62 (1964). 
If the relevant governmental entity has determined that young people should participate, then the views of individual parents should not outweigh that expansion of democratic participation without a sufficiently compelling rationale. ${ }^{114}$

Both sound policy and political theory strongly favor lowering the voting age. The key democratic ideal should be a desire to include as many people as possible in the electorate to improve democratic legitimacy. The mechanism by which we accomplish this voter expansion is extremely important. Local ordinances have begun the reform effort. Victories in small towns can have a "trickle across" and "trickle up" effect, moving to other cities and then states around the country. These municipal laws can serve as the catalyst for nationwide expansion of the right to vote.

\section{B. Noncitizen Voting}

In most local elections in America, and in all federal elections, only U.S. citizens may vote. ${ }^{115}$ But that is not the rule for all local

114 Opponents might suggest that a parent should have the ability to reject a child's desire to vote given a parent's constitutionally protected role in directing the upbringing and education of their children. As one commentator notes,

$[\mathrm{U}]$ nlike those of any adult, the rights of children are always defined in relation to their parents, and parents have an affirmative right and duty to direct the upbringing and education of their children. In part, this right "rests on a presumption that parents possess what a child lacks in maturity, experience, and capacity for judgment required for making life's difficult decisions." The parents' duty similarly rests on their role of preparing the child for the obligations of adulthood.

Jocelyn Floyd, Note, The Power of the Parental Trump Card: How and Why Frazier v. Winn Got It Right, 85 CHI.-Kent L. Rev. 791, 792-93 (2010) (footnotes omitted). Yet even under this rationale, voting is an "obligation of adulthood," suggesting that parents would have a harder time justifying their refusal to allow their children to take part in the election if the local jurisdiction has expanded voting to include them. Indeed, the very fact that the local jurisdiction has granted sixteen- and seventeen-year-olds the right to vote indicates that the polity believes that these youth $d o$ possess the maturity and experience necessary to help make choices for the community - that they are, with respect to voting, the same as adults. That said, there could be compelling individual circumstances, such as a religious objection, that might justify a parent's refusal to allow a minor to vote.

115 For a history of citizenship requirements for voting, see Ron HAYDUK, DEMOCRACY for All: Restoring Immigrant Voting Rights in the United States (2006). Congress has prohibited noncitizens from making campaign contributions to any federal, state, or local elections. See 52 U.S.C. § 30121(a)(1)(A) (2012) ("It shall be unlawful for a foreign national, directly or indirectly, to make a contribution or donation of money or other thing of value, or to make an express or implied promise to make a contribution or donation, in connection with a Federal, State, or local election ...."). Yet this provision does not explicitly forbid voting, as it applies only to campaign expenditures. Further, in arguing to uphold this law against a First Amendment challenge, the federal government noted in its brief, "That some local governments grant noncitizens limited voting rights is irrelevant to the proper disposition of appellants' as-applied challenge, since appellants have not alleged a desire to spend money to influence any local elec- 
elections. Indeed, the U.S. Supreme Court has long recognized that "citizenship has not in all cases been made a condition precedent to the enjoyment of the right of suffrage. Thus, in Missouri, persons of foreign birth, who have declared their intention to become citizens of the United States, may under certain circumstances vote." 116 Indeed, "it appears to be settled doctrine that, so far as the federal Constitution is concerned, alien suffrage is entirely discretionary-neither constitutionally compelled nor constitutionally forbidden." 117 The history of voting rights shows an expansion, and then contraction, of the right to vote for noncitizens. ${ }^{118}$ "[T] $]$ he United States has a long history of noncitizen voting," at least until the 1920s, when xenophobia stemming from World War I reduced voting opportunities across the country for noncitizens. ${ }^{119}$ Even though many people may equate voting with the privilege of citizenship, localities have expanded the right to vote for noncitizens.

Currently, only Takoma Park (which also lowered its voting age $\left.^{120}\right)$ and five other Maryland towns allow noncitizens to vote in all municipal elections. ${ }^{121}$ The Takoma Park rule came about in 1992 after "a task force 'started redrawing voting districts to match the 1990 census and noticed that many districts in the city of 15,000 had disproportionate shares of noncitizens." "122

Some large jurisdictions allow resident noncitizens to vote in certain elections where these individuals may have a particular interest,

tion in which they have the right to vote." Motion to Dismiss or Affirm at 25, Bluman v. FEC, 565 U.S. 1104 (2012) (No. 11-275), 2011 WL 5548718, at *25; see also In re Wehlitz, 16 Wis. 443, 446-48 (1863) (noting that "[u]nder our complex system of government there may be a citizen of a state who is not a citizen of the United States in the full sense of the term" and that "it may be possible for the state to confer the right of voting on certain persons without making them citizens"). Thus, this provision of federal law, which prohibits noncitizens from spending money on political campaigns, does not preempt local laws that allow noncitizens to vote in local elections.

116 Minor v. Happersett, 88 U.S. (21 Wall.) 162, 177 (1874).

117 Gerald L. Neuman, "We Are the People": Alien Suffrage in German and American Perspective, 13 Мich. J. INT'L L. 259, 292 (1992).

118 See HAYDuK, supra note 115 , at 4.

119 See Virginia Harper-Ho, Noncitizen Voting Rights: The History, the Law and Current Prospects for Change, 18 LAW \& INEQ. 271, 271, 282 (2000) (advocating for the expansion of voting rights for resident aliens in local elections); see also id. at 273 ("During the nineteenth century, at least twenty-two states and territories gave voting rights to aliens." (citing Leon E. Aylsworth, The Passing of Alien Suffrage, 25 Am. PoL. Scr. Rev. 114, 114-16 (1931))).

120 See supra Section II.A.

121 Takoma Park, Md., Mun. Code art. VI, § 601(a) (2016) (requiring voters to be "residents" of Takoma Park); see Tara Kini, Comment, Sharing the Vote: Noncitizen Voting Rights in Local School Board Elections, 93 CALIF. L. REv. 271, 296 (2005).

122 Harper-Ho, supra note 119, at 311 (quoting Takoma Park Asks Whether to Give NonCitizens a Say, BALt. Sun, Oct. 27, 1991, at 5B). 
such as for the school board. Chicago, for instance, allows noncitizens to vote in school council elections, as did New York City from 1968 until 2002, when the city disbanded its elected school boards. ${ }^{123}$ Two Massachusetts towns, Cambridge and Amherst, also have passed laws granting the right to vote to noncitizens, but these ordinances cannot go into effect unless the state legislature approves them. ${ }^{124}$

Other jurisdictions are now debating whether to expand the voter rolls to include noncitizens. New York City already allows noncitizens to vote in its Participatory Budgeting elections, which help to direct the allocation of tax funds for specific projects. ${ }^{125}$ The City is further considering an ordinance to allow noncitizens to vote in all elections, which would add up to 800,000 people to the voting rolls. ${ }^{126}$ The proposal, debated in 2013, would allow noncitizen legal residents who have lived in New York City for six months to vote in mayoral and city council elections. ${ }^{127}$ The sponsor of the bill argued that "it's unfair to deny voting rights to law-abiding noncitizens who pay taxes: 'They contribute to society but are ultimately disenfranchised because they cannot vote.' "' ${ }^{128}$ Although thirty-one of the fifty-one New York City Council Members supported the ordinance, Mayor Michael Bloomberg opposed it, and the Speaker of the Council blocked a final vote on the law. ${ }^{129}$ The measure could come before the City Council again, especially as Mayor Bill de Blasio might support the idea. ${ }^{130}$ These examples show that the debate on noncitizen voting is occurring around America, ${ }^{131}$ as well as internationally, such as in Toronto, Vancouver, and various European countries. ${ }^{132}$

123 Kini, supra note 121, at 271 n.1.

124 Id.; $c$. infra Section III.B.

125 See New York City Council, Participatory Budgeting Rulebook 9 (2016), http:// labs.council.nyc/wp-content/uploads/2016/05/PBNYC-2016_2017-Rulebook.pdf; Participatory Budgeting, New York City Council, http://pbnyc.org/ (last visited May 28, 2017).

126 See Aliyah Frumin, NYC Lawmakers Consider Allowing Non-Citizen Immigrants to Vote, MSNBC (May 13, 2013, 8:47 AM), http://www.msnbc.com/hardball/nyc-lawmakers-consid er-allowing-non-citizen-i.

127 See Erin Durkin, Council Weighs Bill to Give Noncitizen Immigrants Voting Rights, N.Y. DAIly News (May 9, 2013, 9:44 PM), http://www.nydailynews.com/news/politics/councilweighs-bill-give-noncitizen-immigrants-voting-rights-article-1.1340007.

$128 I d$.

129 See John Fund, Will New York City Give Non-Citizens the Right to Vote?, NAT'L Rev. (Apr. 6, 2015, 9:40 AM), http://www.nationalreview.com/corner/416495/will-new-york-city-givenon-citizens-right-vote-john-fund.

130 See id.

131 See Around the U.S., IVote, http://www.ivotenyc.org/?page_id=473 [https://perma.cc/ VV6C-3VWH] (last visited May 28, 2017) (providing summary of the debate in various states).

132 See Ayelet Shachar, Earned Citizenship: Property Lessons for Immigration Reform, 23 YALE J.L. \& Human. 110, 130 n.91 (2011). 
Both theoretical and practical reasons support the expansion of voting rights to noncitizens. As Professor and now Congressman Jamie Raskin has explained, "the disenfranchisement of aliens at the local level is vulnerable to deep theoretical objections since resident aliens-who are governed, taxed, and often drafted just like citizenshave a strong democratic claim to being considered members, indeed citizens, of their local communities."133 Put another way, "[a]s a practical matter, noncitizens do not have political power because they do not have the right to vote; inherent in this lack of voting power is an absence of electoral power." 134 Under a prevailing theory of democracy, the government is legitimate only by the consent of the governed, which includes noncitizens who must follow the law; those with equal responsibilities in society should have an equal right to vote. ${ }^{135}$ Moreover, local residents-whether they are citizens or not-care about, and should have a say in, local affairs. Allowing them to vote facilitates greater participation in the community, which may encourage these voters to become citizens. ${ }^{136}$ Expanding noncitizen voting could affect more than ten million legal noncitizen residents in the United States. ${ }^{137}$

From a theoretical standpoint, local jurisdictions should espouse and implement a broad theory of democracy. ${ }^{138}$ Lawful permanent residents have a stake in the governance of their local communities. ${ }^{139}$ At a minimum, noncitizens have a particular interest in school board elections, as they legally send their children to public school. But beyond the substance of this policy recommendation, the location of the

133 Jamin B. Raskin, Legal Aliens, Local Citizens: The Historical, Constitutional and Theoretical Meanings of Alien Suffrage, 141 U. PA. L. REv. 1391, 1394 (1993).

134 Harper-Ho, supra note 119 , at 310-11.

135 See id. at 295-98; see also Bryant Yuan Fu Yang, Note, Fighting for an Equal Voice: Past and Present Struggle for Noncitizen Enfranchisement, 13 Asian AM. L.J. 57, 58 (2006) (advocating for noncitizen voting rights "to promote assimilation, to grant equity, to protect their civil rights, and to provide a viable solution to educational inequities within public schools").

136 Kini, supra note 121, at 272 ("Noncitizen voting in local elections promotes civic participation and citizenship because it gives noncitizens a stake in their communities and a sense that they can make a difference. Exposure to the benefits of civic participation at the local level encourages noncitizens to naturalize so that they can then also participate in state and federal elections."). See generally Kathleen Coll, Citizenship Acts and Immigrant Voting Rights Movements in the US, 15 CitizENSHIP STUD. 993 (2011), https://www.usfca.edu/sites/default/files/pdfs/ faculty/pub-coll-2011citizenshipstudies.pdf (highlighting the impact of enfranchising noncitizens in local elections on "notions of national belonging").

137 See Harper-Ho, supra note 119, at 284.

138 See infra Section III.A.

139 I am not aware of any municipalities that allow illegal aliens to vote. It suffices to say, however, that if someone is in the country illegally, a jurisdiction is more than justified in denying the right to vote to that person. 
debate is also important: this discussion is occurring - and should continue to occur-at the local level. Municipal laws have driven the movement to expand the franchise to noncitizens. ${ }^{140}$

\section{Nonresident Voting}

Various jurisdictions, such as vacation towns, allow nonresident property owners to vote. Eleven states have statutes explicitly permitting nonresidents to vote in local elections if the local jurisdictions so choose. ${ }^{141}$ For instance, in Jefferson County, Tennessee, nonresident property owners who register their property with the local election office may vote in the city's elections. ${ }^{142}$

Delaware's rule is particularly franchise-enhancing. The state's statute provides that if a municipality allows nonresidents to vote, then the municipality may not amend its charter to take that right to vote away. ${ }^{143}$ In essence, the Delaware law is a one-way ratchet: jurisdictions may expand, but not restrict, voting rights in local elections for nonresidents.

The rationale for these rules is to give those who own property a say in the policies that may affect their investment, even if the owners do not live in the town full-time. For instance, the Town of Mountain Village, Colorado, explicitly justified in its town charter its decision to allow nonresident property owners to vote:

1. Like many resorts, the nature of the economy and the lifestyle of the people of the Town are, and will in the future

140 See Raskin, supra note 133, at 1396-97 ("If the democratic argument for alien suffrage in our history can be recaptured and reconstructed, it is possible that Takoma Park will become an early precedent for grass-roots constitutional politics in the twenty-first century.").

141 See Voting by Nonresidents and Noncitizens, Nat'l Conf. St. Legislatures (Feb. 27, 2015), http://www.ncsl.org/research/elections-and-campaigns/non-resident-and-non-citizen-voting.aspx. These states are Arizona, Arkansas, California, Colorado, Connecticut, Delaware, Nebraska, New Mexico, Oregon, Tennessee, and Wyoming. See id. (citing statutes). The National Conference of State Legislatures also lists Montana as allowing local jurisdictions to pass nonresident voting ordinances, but the Montana legislature repealed that provision in 2015. See MonT. Code Ann. § 7-13-2255 (2015).

142 See, e.g., Non-Resident Property Rights Voting, JefFerson County, Tenn., http://www. jeffersoncountytn.gov/government/election-commission/non-resident-property-rights-voting/ [https://perma.cc/4JHJ-6PL9] (last visited May 28, 2017).

143 Del. Code Ann. tit. 22, § 835(b) (2011) ("No municipal corporation charter which permits nonresident persons to vote in any municipal election or to hold any municipal office shall be amended, pursuant to this chapter, so as to eliminate or limit the right of nonresident persons to vote or hold office, nor shall the percentage of nonresident officials allowed or required be changed."); see also Nonresident Property Owners and Voting in Local Elections: A Paradigm Shift?, Canvass: States \& Election Reform, Oct. 2008, at 1-2, http://www.ncsl.org/Portals/1/ documents/legismgt/elect/Canvass_Vol5A.pdf. 
remain, unusual. Furthermore, the fact that many of the Town's present and future residential and commercial property owners maintain their primary residences outside of the Town, making them part-time second-home non-residents, is also unusual. Although these facts are not substantially different from most resort towns, they are very unusual for conventional small as well as large towns.

2. The framers of this Charter took cognizance of the abovementioned singular state of affairs, most especially the fact that a large number of the property owners of the Town are, and will continue to be, only part-time residents of their Town by granting to them the right to vote on those issues that are strictly limited in nature to Town matters. ${ }^{144}$

In a challenge to the Mountain Village charter under the Federal Equal Protection Clause, the Tenth Circuit held that because the rule was franchise-expanding instead of franchise-restricting, rational basis review applied. ${ }^{145}$ Under that standard, the Town had a reasonable justification for allowing nonresident property owners to vote: they "have a sufficient interest in Town affairs."146 Similarly, a Colorado state court ruled that although the Town could not enact a rule that is more restrictive than the state constitution's voter qualification requirements, it could expand voting rules to enfranchise more people for local elections. ${ }^{147}$

Nonresident property owners also have become involved in the political discussion in their communities. For instance, some nonresidents have won seats on the local city council in Rehoboth Beach,

144 May v. Town of Mountain Village, 132 F.3d 576, 579 (10th Cir. 1997) (quoting section 1.4(b) of the town's charter).

145 Id. at 580 ("Of critical importance to any decision here is the fact that Section 2.4(b) of the Town Charter does not restrict the right to vote-it expands it to include nonresidents owning real property in the Town.").

146 Id. at 582; see also Glisson v. Mayor \& Councilmen of Savannah Beach, 346 F.2d 135, 137 (5th Cir. 1965) ("It is apparent from the face of this legislation that there could be a logical and sensible reason for permitting non-residents owning property in the municipality to vote in the municipal elections on an equal basis with resident persons whether or not they are property owners. The nexus between the two is that each of them obviously has an interest in the operation of the city government.").

147 May v. Town of Mountain Village, 969 P.2d 790, 795-96 (Colo. App. 1998). It is unclear, however, how a court might construe a local ordinance that grants multiple votes for individuals who own multiple properties in the locality; granting people additional votes could, in theory, violate the one person, one vote principle of Reynolds v. Sims, 377 U.S. 533 (1964), because some people will have a greater say than others. There might also be a vote dilution concern with respect to resident voters who do not own property. 
Delaware. ${ }^{148}$ Indeed, nonresidents have substantial influence in Rehoboth Beach given that they make up about three-fourths of all property owners. ${ }^{149}$

Yet nonresident property owners likely cannot force a jurisdiction to allow them to vote; a state may validly impose a "single domicile" rule to require voters to choose between voting in their place of domicile or their vacation home. ${ }^{150}$

In sum, nonresident property owners have enjoyed expansion of the right to vote in jurisdictions where the municipality has determined that they have a particular stake in the local elections. ${ }^{151}$ In this way, local laws play a significant role in dictating the size and scope of the electorate.

\section{Other Voting Reforms Through Local Laws}

Although most franchise-enhancing activity at the local level has involved younger voters, noncitizens, and nonresidents, other individuals also have benefited from municipal ordinances. Takoma Park, the first municipality to lower the voting age to sixteen, also enfranchised felons who have completed their sentences. ${ }^{152}$ Reform groups have touted the power of local laws to remove felon disenfranchisement, ${ }^{153}$ but so far, no other jurisdictions have followed suit. Nevertheless, as the organization FairVote has explained, local voting rules can expand access to the ballot, improve Election Day processes, and make voting smoother:

148 See Lisa A. Phillips, The Principle of 2nd Home, 2nd Vote, N.Y. Times (June 22, 2007), http://www.nytimes.com/2007/06/22/realestate/greathomes/22politics.html.

149 Id. Nonresident political activity also encompasses more than just voting: "For Rehoboth Beach's concerned part-timers, involvement often goes beyond the voting booth. Some say they routinely stretch their weekends to attend Monday night meetings of the board of commissioners, the city's governing body." Id.

150 See, e.g., Wit v. Berman, 306 F.3d 1256, 1260, 1263 (2d Cir. 2002) (upholding New York Election Law that forbids individuals from voting in multiple locations against challenge from voters who own vacation homes). But see Ashira Pelman Ostrow, Note, Dual Resident Voting: Traditional Disenfranchisement and Prospects for Change, 102 Colum. L. REv. 1954, 1958 (2002) (arguing that "excluding dual residents from voting in a second-home community simply because they are also registered to vote in another community violates the Equal Protection Clause").

151 As an international analogy, some countries allow nonresident citizens who live in a different country to vote in the homeland's elections. See Caroline Carter, Note, The Right to Vote for Non-Resident Citizens: Considered Through the Example of East Timor, 46 TEX. INT'L L.J. 655, 671 (2011).

152 See Powers, supra note 12; supra Section II.A.

153 See FairVote, The Municipal Right to Vote: The Future of Voting Rights, http:// archive.fairvote.org/media/rtv/munitwopager.pdf (last visited May 28, 2017). 
The breadth of issues that could be addressed through a Municipal Right to Vote are infinite, though research must be done to ascertain what powers a particular state has granted to cities for election administration. Nevertheless, it seems clear that at least some cities could use a Municipal Right to Vote to pass felon re-enfranchisement, election day or universal voter registration, paper ballots, early and weekend voting, foreign language ballots, and other such ordinances for city elections. ${ }^{154}$

As another example, municipalities could use local laws to promote compulsory voting, which ultimately could spread nationwide. ${ }^{155}$

Moreover, even if municipalities do not target a specific group of voters, they can enact resolutions touting the importance of voting. Takoma Park, Maryland, passed a resolution affirming that "an individual right to vote is a fundamental American right, and fundamental rights should be guaranteed to all Americans in the U.S. Constitution." 156 Although this resolution does not have any force of law, it still provides a beneficial signal to Takoma Park's residents that the City takes the importance of voting seriously. Given that voting actually happens at local precincts, this signal can have a significant impact on the civil discourse among the electorate. ${ }^{157}$ Similarly, Montgomery County, Maryland, convened a Right to Vote Task Force that issued a seventy-six page report with various recommendations for improving the voting process, such as enhancing online registration, adopting same-day voter registration, and improving ballot design, among others. ${ }^{158}$ Once again, while not having the force of law itself, this report is highly influential in beginning a needed conversation-among those who actually administer elections-on best practices. Because it is easier to enact local laws than state or national laws, these kinds of resolutions can serve as catalysts for broader reform.

154 Id.

155 See Nicholas Stephanopoulos, A Feasible Roadmap to Compulsory Voting, Atlantic (Nov. 2, 2015), http://www.theatlantic.com/politics/archive/2015/11/a-feasible-roadmap-to-com pulsory-voting/413422/ ("[I]f reformers were to start at the municipal level, they could set into motion forces that might lead to its nationwide adoption.").

156 City of Takoma Park, Md., Res. 2013-25 (May 13, 2013) http://www.promoteourvote. com/uploads/9/2/2/7/9227685/takoma_park_right_to_vote_resolution.pdf.

157 Cf. Joshua A. Douglas, Election Law and Civil Discourse: The Promise of ADR, 27 Ohio St. J. on Disp. Resol. 291, 299-300 (2012) (discussing the role of courts and the media on civil discourse).

158 Montgomery Cty. Right to Vote Task Force, Report of the Right to Vote TASK ForCE (2014), http://www.montgomerycountymd.gov/COUNCIL/Resources/Files/RE PORTS/RightToVoteTaskForce/RightToVoteTaskForceReport.pdf. 


\section{POLICY AND LAW}

Debate on local voting rights is nascent yet robust. More and more jurisdictions are contemplating whether to expand the franchise or otherwise alter the rules for local elections. ${ }^{159} \mathrm{We}$ should encourage our policymakers across the country to join this movement. Civil reforms often start at the local level. Given that municipalities elect their own governments, they should dictate who may participate in those elections.

Yet inevitably, as localities enact ordinances expanding the right to vote, courts will be called upon to judge their validity. Someone may bring a lawsuit once a municipality passes an ordinance or in the context of an election itself. Or perhaps, in a close election, the losing candidate will argue that the election results are invalid because the city allowed some people to vote who otherwise should not enjoy the franchise. Either way, in this age of highly litigious campaigns, a judicial challenge is quite likely. Courts therefore need a theoretical framework to decide the validity of these local rules on voting rights.

As this Part explains, city and town elected officials, and the people themselves, may grant the right to vote to previously excluded individuals. Localities should expand voting rights because doing so will include more people in the process, create a habit of voting (especially for younger voters), make government more responsive to local constituencies, and enhance the legitimacy of the winners. ${ }^{160}$ If there are explicit state constitutional or legislative hurdles to local control of elections, then states should reform their laws. Courts, when faced with a challenge to a local rule expanding the franchise, should defer to the local ordinance with a presumption of validity if there is any room under state law to allow the voter expansion.

\section{A. Benefits of Expanding the Electorate}

Localities should reform their rules on the right to vote by broadening the electorate. In particular, cities and towns should enact ordinances that affirm the importance of voting and expand voter access. As Alexis de Tocqueville once said, "local assemblies of citizens constitute the strength of free nations. ... A nation may establish a sys-

159 See Joshua A. Douglas, Local Democracy on the Ballot, 111 Nw. U. L. Rev. OnLine 173, 178-84 (2017), http://northwesternlawreview.org/online/local-democracy-ballot.

160 See supra Part II. 
tem of free government, but without the spirit of municipal institutions it cannot have the spirit of liberty."161

Political inclusiveness is inherently desirable to increase the legitimacy of elected officials. ${ }^{162}$ A common theory of democracy is that the people subject to a government and its laws must collectively consent to societal rules through elections. ${ }^{163}$ Increased participation will help to make elected officials more responsive to the local population. As a general rule, then, greater participation is good for democratic legitimacy.

People are closest to their local representatives. ${ }^{164}$ If democratic legitimacy stems from enjoying the consent of the governed, then the "governed" should include as many competent people as possible who have a stake in governmental affairs. ${ }^{165}$ Local governments pass many laws that have real world effects every day. Individuals often are actively involved in their community debates; democracy flourishes the most at the local level. Broadening the right to vote in local elections is thus paramount to achieving a well-functioning democracy.

Localities should expand the right to vote by adopting a theory of democracy that favors inclusiveness. ${ }^{166}$ Crafting a local right-to-vote ordinance will force communities to delineate who has a stake in local

1611 Alexis de Tocoueville, Democracy in America 60 (Henry Reeve trans., Colonial Press 1899).

162 See John Payton, Democracy and Diversity, 35 PePp. L. Rev. 569, 572, 581-82 (2008); cf. Grutter v. Bollinger, 539 U.S. 306, 332 (2003) ("Effective participation by members of all racial and ethnic groups in the civic life of our Nation is essential if the dream of one Nation, indivisible, is to be realized.").

163 See, e.g., David M. Estlund, Democratic Authority: A Philosophical FrameWORK 66 (2008) ("Democracy, the authorization of laws collectively by the people who are subject to them, is inseparable from voting."); see also Hamilton, supra note 100, at 1476 ("A typical account of democracy provides that, in order for a political system to qualify as democratic, the people subject to its laws must collectively authorize them. A democratic government thus derives its authority from the 'the people' who are the individual members of the political community." (footnote omitted)).

164 As Professor Heather Gerken has described, our political system is highly decentralized, with important governmental units that are even smaller than cities or towns. Thus, she argues, recognizing "federalism-all-the-way-down" would include an inquiry into the processes of special-purpose governmental units. See Heather K. Gerken, Foreword: Federalism All the Way Down, 124 Harv. L. Rev. 4, 22 (2010). Considering "federalism-all-the-way-down" provides further support for expanding voting rights for the smallest governmental units that hold elections.

165 See Hamilton, supra note 100 , at 1479.

166 Cf. Holder v. Hall, 512 U.S. 874, 897 (1994) (Thomas, J., concurring in the judgment) ("The choice [between governmental structures] is inherently a political one, and depends upon the selection of a theory for defining the fully 'effective' vote-at bottom, a theory for defining effective participation in representative government. In short, what a court is actually asked to do in a vote dilution case is 'to choose among competing bases of representation-ultimately, 
governance. This action will make local governments more responsive to all of their constituents and better expositors of local democracy.

As a guiding principle, municipalities should enfranchise individuals who have a sufficiently close nexus to local governance and have both the ability and the incentive to make informed choices about who should lead them. ${ }^{167}$ In essence, the current governing body or electorate of a city or town should decide that current nonvoters have a sufficient stake in local affairs such that the jurisdiction should include them in local democracy. State constitutions and state legislation already provide a baseline for an eligible voter: someone who is at least eighteen years old, a U.S. citizen, a resident of the relevant jurisdiction, not mentally incompetent, and (in most states) not a felon. ${ }^{168}$ The sacred value inherent in participatory democracy allows, if not encourages, local jurisdictions to add to that list. Perhaps many children of noncitizens are enrolled in a town's schools such that their parents should have input in school governance. ${ }^{169}$ Perhaps nonresidents who work in the town or own property there should have a say over local taxation. ${ }^{170}$ Perhaps the current electorate finds that sixteen- and seventeen-year-olds have a sufficient stake in local laws and that they are cognitively competent enough to make informed voting decisions such that the municipality should lower the voting age. ${ }^{171}$ Greater voting participation from these groups can also lead to greater participation in other civic endeavors. Of course, the current municipal governing body would have to expand the right to vote to additional groups, so current politicians and their constituents must decide to include more people. ${ }^{172}$ Sound policy arguments have al-

really, among competing theories of political philosophy.' " (quoting Baker v. Carr, 369 U.S. 186, 300 (1962) (Frankfurter, J., dissenting))).

167 See Hamilton, supra note 100, at 1482-83 (highlighting the two criteria that most political theorists have identified as requirements for electoral inclusion: connection to the community and competence to make voting decisions).

168 See Douglas, supra note 6, at 101-02.

169 See Kini, supra note 121, at 271 n.1.

170 See, e.g., Non-Resident Property Rights Voting, supra note 142.

171 See supra Section II.A.

172 As David Schleicher convincingly argues, discerning who has the authority to expand voter access presents a "boundary problem": why should today's current electorate have any say in formulating the scope of tomorrow's electorate? See David Schleicher, The Boundary Problem and the Changing Case Against Deference in Election Law Cases: Lessons from Local Government Law, 15 ELECTION L.J. 247, 249-250 (2016). Yet the reality is that current legislators or voters (through ballot initiatives) do enact laws that dictate voter qualifications. Id. at 255 . Theory aside, the way to expand the franchise to additional groups is to have the current legislators or voters do so. 
ready convinced some jurisdictions to expand the right to vote. Other cities and towns should follow suit.

\section{B. Local Jurisdictions as "Test Tubes of Democracy"}

Over eighty years ago, Justice Louis Brandeis famously referred to the states as "laboratories of democracy" that can experiment with different laws to see what works best. "[A] single courageous State may, if its citizens choose, serve as a laboratory; and try novel social and economic experiments without risk to the rest of the country." ${ }^{173}$ Yet although we have fifty states-fifty laboratories-we also have tens of thousands of cities and towns that also make laws that affect their citizens. ${ }^{174}$ Each of these municipalities also could enact local laws to "try novel social and economic experiments," 175 such as on the right to vote. If states are laboratories of democracy, then municipalities are, in essence, "test tubes of democracy," experimenting with democratic processes on an even smaller scale. ${ }^{176}$

The prevailing notion of voting rights law is that "eligibility to vote is defined in the first instance by state law, although the contours of that state law are subject to a series of overriding federal constraints." ${ }^{177}$ But local government law may also play a role. Municipalities can expand voting rights in local elections if there are no explicit state constitutional or legislative impediments and so long as local jurisdictions have the power of home rule. ${ }^{178} \mathrm{We}$ must recognize the im-

173 New State Ice Co. v. Liebmann, 285 U.S. 262, 311 (1932) (Brandeis, J., dissenting).

174 See Richard Briffault, Home Rule and Local Political Innovation, 22 J.L. \& PoL. 1, 31 (2006) [hereinafter Briffault, Home Rule] ("[I]f the fifty states are laboratories for public policy formation, then surely the 3,000 counties and 15,000 municipalities provide logarithmically more opportunities for innovation, experimentation and reform. Thousands of local governments provide thousands of arenas for innovation and for testing the costs and benefits of those innovations."); Richard Briffault, Our Localism: Part II-Localism and Legal Theory, 90 CoLum. L. REv. 346, 346 (1990) ("There are more than 82,000 local governments in the United States ....").

175 New State Ice Co., 285 U.S. at 311 (Brandeis, J., dissenting).

176 See, e.g., Paul Diller, Intrastate Preemption, 87 B.U. L. Rev. 1113, 1114 (2007) ("In the sheer number of laboratories offered, local governments dwarf the mere 50 states: there are 15,000 municipalities and 3,000 counties, as well as 35,000 special-purpose districts." (footnotes omitted)); Robert C. Holmes, The Clash of Home Rule and Affordable Housing: The Mount Laurel Story Continues, 12 Conn. Pub. INT. L.J. 325, 332 (2013) ("Local self-government also promotes policy innovation and experimentation. Similar to federalism's facilitation of statelevel innovation, local autonomy permits local governments to serve as 'laboratories of democracy' and 'to try novel social and economic experiments without risk to the rest of the country.'" (quoting New State Ice Co., 285 U.S. at 311 (Brandeis, J., dissenting))).

177 Pamela S. Karlan, Framing the Voting Rights Claims of Cognitively Impaired Individuals, 38 McGeorge L. Rev. 917, 919 (2007).

178 See infra Sections III.C.1, III.C.2. 
portance of local laws in defining and shaping the electorate, at least for municipal elections. Moreover, these local rules can have a nationwide impact as they spread throughout the country.

Local laws are easier to pass than state or federal legislation. Local ordinances typically are more "streamlined," meaning that "there is a greater possibility that more single-issue laws overall will be passed via local governments than by higher levels of government." 179 As the Utah Supreme Court has recognized,

the history of our political institutions is founded in large measure on the concept-at least in theory if not in practice-that the more local the unit of government is that can deal with a political problem, the more effective and efficient the exercise of power is likely to be. ${ }^{180}$

Local governments are more effective because they are closer to their constituents. ${ }^{181}$ Moreover, localities often elect their officials in "nonpartisan" elections, which might temper the partisanship that infiltrates state and federal lawmaking. ${ }^{182}$ In essence, passing a right-tovote ordinance at the local level is easier than through a statewide or federal constitutional amendment or statutory change.

Local laws can spread throughout the country once other jurisdictions see the new rules working well. ${ }^{183}$ Social movements may begin after one locality adopts a reform to great success, causing other municipalities to emulate the first mover. Justice Brandeis's invocation of the "laboratories of democracy" metaphor posits that states will adopt the best ideas tested initially in one courageous state. ${ }^{184}$ Yet cities and

179 See Kellen Zale, Urban Development Legislation for Cities, by Cities, 67 ME. L. REv. 266, 267 (2015).

180 State v. Hutchinson, 624 P.2d 1116, 1121 (Utah 1980).

181 See Michael M. O'Hear, Federalism and Drug Control, 57 VAnd. L. Rev. 783, 860 (2004) ("Individual citizen voice grows as the size of the electorate shrinks; . . if fifty state-level 'laboratories of democracy' are good, then the tens of thousands of laboratories provided by local government might be even better.").

182 See Karen I. Chang, Note, The Party's Over: Establishing Nonpartisan Municipal Elections in New York City, 11 J.L. \& PoL'y 579, 579 (2003) ("Today, a majority of the nation's cities utilize nonpartisan elections, and sixty of the seventy-five largest U.S. cities have elected their mayors in nonpartisan elections." (footnote omitted)); Nancy Northup, Note, Local Nonpartisan Elections, Political Parties and the First Amendment, 87 Colum. L. Rev. 1677, 1677 (1987) ("Most local elections in America are nonpartisan."). Of course, local consideration of election rules could lead to an increase in the partisanship of local elections.

183 See Briffault, Home Rule, supra note 174, at 32 (noting that local experimentation entails few external costs but many external benefits in "providing new information about the consequences of particular innovations"); see also supra Part I.

184 See New State Ice Co. v. Liebmann, 285 U.S. 262, 311 (1932) (Brandeis, J., dissenting). Justice O'Connor, in discussing the women's suffrage movement and the fact that Wyoming was 
towns may be even more important in being the first movers, particularly for social issues. ${ }^{185}$ As Professor Diller explains:

City policy experimentation is a catalyst for change at the state and national levels. From gay rights to the environment to public health, cities and other forms of local government are adopting new and innovative policies in the wake of inaction by the higher levels of government.

Cities have increasingly led in enacting new policies in a wide variety of areas, including living-wage laws, workers' rights, global warming reduction, public financing of campaigns, trans fats regulation, affordable housing, universal health care, environmental protection, gay rights, and smoking prevention. ${ }^{186}$

Municipalities were the first governmental entities to pass laws on these significant social issues, which then eventually spread to other cities and states:

These examples illustrate a widespread pattern of policy innovation: a policy first embraced by a city proves itself manageable and popular at the local level before percolating "out" to other cities and "up" to the state level. Without the possibility of city experimentation, these policies might have never been embraced by other jurisdictions. ${ }^{187}$

The fight for expanded rights for gays and lesbians provides a good example: although many local jurisdictions continued to discriminate, the social movement that eventually led to the constitutional recognition of same-sex marriage saw some initial successes through local nondiscrimination ordinances. ${ }^{188}$

the first state to allow women to vote when it became a state in 1890 , noted that, "Courts and commentators frequently have recognized that the 50 States serve as laboratories for the development of new social, economic, and political ideas." FERC v. Mississippi, 456 U.S. 742, 788 (1982) (O'Connor, J., concurring in the judgment in part and dissenting in part).

185 See, e.g., Sims v. Besaw's Café, 997 P.2d 201, 213 n.3 (Or. Ct. App. 2000) (en banc) (noting that "municipalities tend to be the proving grounds-in terms of both need and public acceptance-for nondiscrimination policies that later are adopted at state and national levels").

186 Diller, supra note 176, at 1113-14, 1117-18 (footnotes omitted) (arguing for state courts to adopt a theory of "intrastate preemption that facilitates good-faith policy experimentation by cities, while discouraging parochial and exclusionary municipal action").

187 Id. at 1119.

188 See James W. Button et Al., Private Lives, Public Conflicts: Battles over Gay Rights in American Communities 69 (1997) (noting that local nondiscrimination ordinances applying to sexual orientation date to the 1970s); William N. Eskridge, Jr., Channeling: IdentityBased Social Movements and Public Law, 150 U. PA. L. Rev. 419, 462 (2001) ("Success in baby steps at the local level was a spur to the social movement, both by demonstrating to still-closeted 
Indeed, with respect to another election law issue-public financing of campaigns-cities have taken the lead. Although New York City's successful public financing scheme is the most prominent example, ${ }^{189}$ smaller jurisdictions such as Boulder, Colorado, and Tucson, Arizona, also have local public financing regimes for their city elections. ${ }^{190}$ Their successes have encouraged other cities to move forward with their own innovations. ${ }^{191}$ In 2014, Montgomery County, Maryland, adopted public financing rules for local campaigns. ${ }^{192}$ In 2015, Seattle voters adopted an innovative campaign finance system to use "democracy vouchers," in which the city mails voters four vouchers worth $\$ 25$ each for the voter to assign to candidates for local office who agree to various campaign finance limitations. ${ }^{193}$ Advocates for campaign finance reform are eagerly watching Seattle's experiment to see if they want to seek its adoption in other cities.

The movement for expanded voting rights also can begin at the local level and radiate out to other cities and then states in a "trickle

gay people that the movement could be successful and by illustrating how far gay people had to go to achieve full legal equality."); see also Obergefell v. Hodges, 135 S. Ct. 2584 (2015) (holding that the right to marry for same-sex couples is a fundamental constitutional right). Local backlash against gays and lesbians followed the initial successes, which may have slowed the movement toward recognition of same-sex marriage. See, e.g., William N. Eskridge Jr., Backlash Politics: How Constitutional Litigation Has Advanced Marriage Equality in the United States, 93 B.U. L. REv. 275, 281 (2013) ("When Hawaii's supreme court suggested that gay marriage might be recognized in that state, there was a powerful local backlash and a ferocious national one that set back the marriage equality movement in many respects.").

189 See Spencer Overton, Matching Political Contributions, 96 Minn. L. Rev. 1694, 1697 (2012) (noting that "candidates in New York City (the only American jurisdiction with six-toone multiple matching funds) collect over half of their money from contributors who give $\$ 250$ or less").

190 See Steven M. Levin, Ctr. for Governmental Studies, Keeping it Clean: Public FinANCing in American Elections 116-18 (2006), http://users.polisci.wisc.edu/kmayer/466/ Keeping_It_Clean.pdf [https://web.archive.org/web/20170107010513/http://users.polisci.wisc.edu/ kmayer/466/Keeping_It_Clean.pdf] (listing twelve jurisdictions with public financing systems for local elections as of 2006).

191 See Briffault, Home Rule, supra note 174, at 32 ("We know far more about the workability, benefits, and costs of [instant runoff voting] and public funding of election campaigns as a result of the innovative actions of cities like San Francisco, Tucson, Los Angeles, and New York.").

192 See Bill Turque, Montgomery Council Approves Plan for Public Finance of Local Campaigns, WAsh. Post (Sept. 30, 2014), https://www.washingtonpost.com/local/md-politics/mont gomery-council-approves-plan-for-public-finance-of-local-campaigns/2014/09/30/b3e2b15c-482d11e4-b72e-d60a9229cc10_story.html.

193 See Seattle, Wash., Mun. Code $\$ \$ 2.04 .600-2.04 .690$ (2017), https://www.muni code.com/library/wa/seattle/codes/municipal_code?nodeId=TIT2EL_CH2.04ELCACO_SUB CHAPTER_VIIIHOELSE; Bob Young, 'Democracy Vouchers' Win in Seattle; First in Country, Seattle Times (Nov. 4, 2015, 6:20 AM), http://www.seattletimes.com/seattle-news/politics/demo cracy-vouchers/. 
across" and "trickle up" mechanism. For instance, many Americans disagree with existing policies that disenfranchise felons who have completed their sentences. ${ }^{194}$ Advocates could look to local jurisdictions to reform the law. Successes at the local level, with felons voting in municipal elections without any issues, will then arm supporters with better evidence on the positive aspects of felon re-enfranchisement and will help to bolster democratic representation. ${ }^{195}$ Smaller victories at the municipal level can breed broader wins city by city and state by state. As advocates for a Municipal Right to Vote ordinance explain:

Municipal reform is often overlooked, but it can be one of the most efficient and potent methods of fostering political change. The Municipal Right to Vote Initiative seeks to have cities call for a constitutional right to vote and to pledge to enact ordinances and charter changes in the spirit of that proposed amendment, thereby building both political support for an amendment and showcasing what it would mean for protecting and expanding suffrage. ${ }^{196}$

Municipalities should pass an ordinance on voting rights that expands the electorate for local elections to those who have a direct, personal stake in the outcome.

Of course, local political actors could alter voting rules to entrench themselves in power, which is a more concerning use of local voting rights. ${ }^{197}$ Local politicians could enact ordinances that reduce voting opportunities or exclude certain groups of voters. Yet the fact that the federal and state constitutions provide a baseline for voting rights protection tempers that concern. A local jurisdiction cannot deny the right to vote to anyone who is a citizen of the United States,

194 See John Ghaelian, Restoring the Vote: Former Felons, International Law, and the Eighth Amendment, 40 Hastings Const. L.Q. 757, 780 (2013) ("Public opinion polling conducted on the matter also demonstrates a national consensus against felon disenfranchisement."); Jeff Manza et al., Public Attitudes Toward Felon Disenfranchisement in the United States, 68 PuB. OpINION Q. 275, 280-81 (2004), http://as.nyu.edu/docs/IO/3858/Public_Attitudes_Towards_ Felon_Disenfranchisement_Laws_in_the_US.pdf; Matt Ferner, Americans Don't Think Ex-Offenders Should Lose Their Right to Vote, Huffington Post (Apr. 26, 2016, 6:41 PM), http:// www.huffingtonpost.com/entry/ex-convict-voting-rights_us_571fb9d5e4b0b49df6a95746.

195 See Lynn Eisenberg, Note, States as Laboratories for Federal Reform: Case Studies in Felon Disenfranchisement Law, 15 N.Y.U. J. Legis. \& Pub. PoL'y 539, 576 (2012) (noting that "the 'laboratories of democracy' approach can and has applied to the expansion of voting rights," including through the repeal of felon disenfranchisement rules).

196 Usman Ahmed et al., A Municipal Right to Vote, Nat'L Civic Rev., Summer 2008, at 52, 52, http://deepblue.lib.umich.edu/bitstream/handle/2027.42/60453/215_ftp.pdf?sequence=1.

197 See Samuel Issacharoff \& Richard H. Pildes, Politics as Markets: Partisan Lockups of the Democratic Process, 50 StAn. L. Rev. 643, 647 (1998); Schleicher, supra note 172, at 247. 
a resident of the state and locality, at least eighteen years old, and not mentally incompetent. ${ }^{198}$ In addition, under the U.S. Constitution, municipalities may not discriminate on the basis of sex, race, or other protected characteristics, ${ }^{199}$ and local jurisdictions also may not limit the electorate by espousing a narrow view of who they believe has an actual stake in the outcome. ${ }^{200}$ Federal and state statutes also prevent discrimination in voting. ${ }^{201}$ Thus, if legislating directly on who may vote, local jurisdictions can go nowhere besides up, expanding voter access.

With greater attention to voting rules, however, municipalities also could enact indirect measures to restrict voting. Jurisdictions could, for example, legislate on where to place precincts, reduce the number of machines at certain polling sites, or make redistricting decisions that effectively exclude some people from the relevant jurisdiction. ${ }^{202}$ Although not about voter qualifications per se, these rules could effectively hamper the right to vote for some people. In fact, in the wake of the Supreme Court's decision in Shelby County $v$. Holder $^{203}$ invalidating a provision of the Voting Rights Act, many (typically Republican-controlled) jurisdictions have passed laws that have the goal, or at least effect, of disenfranchising minority voters. ${ }^{204}$ For this reason, courts should train a more skeptical eye on measures

198 See U.S. Const. amend. XIV, § 2; Douglas, supra note 6, at 101-05 (highlighting state constitutional rules for voter eligibility); see also Michael T. Morley, Remedial Equilibration and the Right to Vote Under Section 2 of the Fourteenth Amendment, 2015 U. Chi. Legal F. 279, 283 (pointing to Section 2 of the Fourteenth Amendment as delineating the scope of the constitutional protection for the right to vote); Franita Tolson, The Constitutional Structure of Voting Rights Enforcement, 89 WASH. L. REv. 379, 384-85 (2014) (arguing for an expansive understanding of Congress's authority to regulate the right to vote under the Fourteenth Amendment).

199 See Douglas, supra note 7, at 151.

200 Kramer v. Union Free Sch. Dist. No. 15, 395 U.S. 621, 629, 632 (1969).

201 See, e.g., 52 U.S.C. $\$ 10301$ (2012) (Federal Voting Rights Act); CAL. Elec. Code $\S \S 14025-14032$ (West 2003) (California Voting Rights Act).

202 See, e.g., Arizona Democrats Say Cost-Saving Resulted in Voter Suppression, WTKR (March 23, 2016, 3:11 PM), http://wtkr.com/2016/03/23/arizona-democrats-say-cost-saving-re sulted-in-voter-suppression/ ("Liberal activists are demanding an investigation into what they see as possible voter suppression as a result of Maricopa County officials' decision to reduce the number of polling stations as a cost-saving measure.").

203133 S. Ct. 2612 (2013).

204 See Harry Baumgarten \& Jacob Zionce, Shelby County v. Holder's Biggest and Most Harmful Impact May Be on Our Nation's Smallest Towns, CAMPAign Legal Ctr. (June 20, 2016), http://www.campaignlegalcenter.org/news/blog/shelby-county-v-holder-s-biggest-andmost-harmful-impact-may-be-our-nation-s-smallest; Democracy Diminished: State and Local Threats to Voting Post-Shelby County, Alabama v. Holder, NAACP LegAl Def. \& Educ. Fund (June 9, 2016), http://www.naacpldf.org/publication/democracy-diminished-state-and-local -threats-voting-post-shelby-county-alabama-v-holder. 
that restrict the right to vote. From a normative perspective, we should encourage more, not less, voter participation as a means of creating a better functioning and more representative democracy. The more people who participate, the more likely the winning candidate actually will reflect the desires of the majority of the population, thereby improving the representative's legitimacy. Thus, enfranchising additional people should not come with a license to pass laws that restrict voting rights. In contrast, jurisdictions should freely experiment with laws that expand voter access in a nondiscriminatory way. That is, measures that expand the right to vote are qualitatively different from rules that (directly or indirectly) restrict democratic participation, so local governing bodies and courts should treat the two kinds of measures differently.

But what about laws that expand voter access for some at the expense of others? For instance, a local rule placing more precincts in one part of town to assist voters in those neighborhoods might hurt voters in another part of town that now has fewer precincts. The expand/restrict dichotomy for voting rights may not always break down into neat categories. Although some rules might have differing effects, the key question policymakers should ask is whether, as a whole, the primary purpose or effect is to expand voting rights in a nondiscriminatory way. This formulation is similar to the concept of retrogression $^{205}$ : if the status quo is the baseline, then does the new local rule make voters, in the aggregate, better or worse off in a nondiscriminatory manner? Courts could also use a primary purpose or effect test to decide whether the local rule is mostly expansive or restrictive toward voting rights, which will direct the level of deference. ${ }^{206}$ Furthermore, all of the various constitutional and legislative backstops to voting discrimination still apply. Thus, when considering local legislative motivations, the key question is whether the local jurisdiction is, as a whole, attempting to expand voting rights in a nondiscriminatory and noninvidious manner.

Of course, states that oppose these local voter expansions could pass state laws that expressly preempt local action. But states should not do so for all of the policy reasons discussed above: municipalities

205 See 52 U.S.C. $\S 10304$ (a) (prohibiting voting rules that have "the purpose [or] the effect of denying or abridging the right to vote" to minorities); Nathaniel Persily, The Promise and Pitfalls of the New Voting Rights Act, 117 YALE L.J. 174, 217 (2007) (explaining the "new retrogression" standard of the Voting Rights Act).

206 See infra Section III.C.3 (discussing the level of deference a court should give to local voting rules); $c f$. Miller v. Johnson, 515 U.S. 900, 910, 917 (1995) (applying a "predominant, overriding factor" analysis to the purpose inquiry for a claim of racial gerrymandering). 
should have the power to dictate the scope of their own governmental structures and electorate, and localities should experiment and innovate with their voting rules. If a state legislature insists on preempting local voting laws, however, then the solution is to elect different state representatives who will support local democracy.

Even in states in which local jurisdictions do not have the legal authority to expand voting rights-meaning that a local ordinance cannot have any actual legal effect-a municipal statement on the right to vote can still spur the debate and send a signal to the legislature. Amherst, Massachusetts, for example, has passed several ordinances on noncitizen voting that cannot go into effect without the state legislature's approval. ${ }^{207}$ Yet Amherst's enactments are not in vain. Simply declaring the importance of the constitutional right to vote and attempting to expand the franchise creates an environment in which legislators, and the general public, actively debate these issues. Social change can succeed through grassroots organization, meaning that local jurisdictions are well suited to act as the catalyst for this issue. The statement can still have an impact even if it does not have the force of law.

Every city or town should pass a resolution affirming the importance of the right to vote. Further, jurisdictions should expand the right to vote to include sixteen- and seventeen-year-olds, noncitizens (who are lawful permanent residents), nonresident property owners, felons who have completed their sentences, or any other group who currently may not vote but, the polity believes, has a sufficient nexus to the local community and a stake in local governance and policy. Denying voting rights to these individuals should result from considered judgment instead of simply maintaining the status quo through inertia. Once jurisdictions carefully examine the experience of the few courageous cities that have taken the lead, they will recognize the policy wisdom of expanding the franchise.

\section{Law}

Four potential hurdles could hamper local expansion of the right to vote. None are insurmountable, but they all require careful thought for advocates of local voting rights.

First, some state constitutions or legislation set specific voter qualifications and couch them as restrictions, meaning that local gov- 
ernments may not go beyond these substantive provisions. ${ }^{208}$ In essence, mandatory state law might preempt local voting rules. States with these rules should amend their constitutions or laws to allow local governments to set different standards for local elections. Second, some state constitutions or statutes do not grant municipalities home rule, or local power, over local elections. These states should change their home rule doctrine. Third, court challenges based on state law preemption or lack of home rule power could derail local movements. ${ }^{209}$ Given that municipalities are continuing to enact right-tovote rules that expand voter access, a lawsuit seeking to invalidate one of these laws is inevitable, either through direct litigation or within the context of a disputed election. Courts therefore must have the proper tools and tests ready to decide these cases. If any room exists under state constitutional or statutory law to give cities and towns authority to expand voter qualifications for their own elections, then courts should defer to these local bodies in their own explication of local democracy. Finally, administrators must solve the practical problem of running an election where some voters may vote for certain offices (local races) but not others (national or state elections). Voting technology provides a fairly easy solution to this concern.

The ability to expand voting rights at the local level will depend on the nature of existing state law. Some states must pass a constitutional amendment or legislative act to remove specific restrictions on expanding voter access. In other states, the legislature must change the existing home rule doctrine. ${ }^{210}$ Strong policy reasons support both reforms. But many states do not have specific language on voter qualifications or home rule. In those states, local jurisdictions should enact ordinances expanding the electorate for local elections. In a court challenge, judges should defer to the local laws under a theory of representation that allows the local government to choose for itself what kind of participatory democracy it wants for its own elections.

208 A White Paper from Generation Citizen, a nonprofit advocacy group seeking to lower the voting age, deftly explains the difference between a "grant" of the right to vote and a "restriction": "The Ohio Constitution, for example, says 'Every citizen of the United States, of the age of eighteen years . . . is entitled to vote at all elections.' This phrase can be interpreted two ways: either (1) the right to vote is given exclusively to citizens over the age of 18 [a restriction], or (2) while those over 18 cannot be denied the right to vote, voting rights could be granted on a discretionary basis to those under 18 [a grant]." See Generation Citizen, supra note 86, at 17 (ellipsis in original).

209 See Briffault, Home Rule, supra note 174, at 3.

210 The Appendix lists, in tabular form, the potential hurdles to local voting rights laws in each state. 


\section{State Constitutional or Legislative Rules on Voter Qualifications}

Some state constitutions or statutes set maximum voter qualifications, leaving no room for local jurisdictions to change these qualifications for local elections. ${ }^{211}$ In essence, state law explicitly preempts local rules that differ. In these states, advocates of local expansion of voting rights must amend the constitution or change state law using the policy arguments discussed above..$^{212}$

For instance, a state constitution might explicitly set the voting age at eighteen. The Texas Constitution provides, "The following classes of persons shall not be allowed to vote in this State: (1) persons under 18 years of age." 113 Similarly, Virginia's constitution states, "Each voter shall be a citizen of the United States, shall be eighteen years of age, shall fulfill the residence requirements set forth in this section, and shall be registered to vote pursuant to this article." 214 Given the mandatory word "shall," little wiggle room exists within this provision for a local jurisdiction to lower the voting age or expand voting to noncitizens or nonresidents. Advocates of local voting rules in these states must seek to amend the constitution.

But many state constitutions are not so restrictive-at least not explicitly. Just like the Federal Constitution, most state constitutions simply provide a floor for voter qualifications. ${ }^{215}$ They dictate criteria like citizenship and age, but they do not forbid further expansion. ${ }^{216}$ For instance, the Kentucky Constitution provides, "Every citizen of the United States of the age of eighteen years who has resided in the state one year, and in the county six months, and the precinct in which he offers to vote sixty days next preceding the election, shall be a voter in said precinct." 217 That is, although the state constitution sets the voting age at eighteen, nothing in this provision prevents a local government from issuing a more expansive rule and lowering the voting age for its own elections. Despite listing several qualifications, the constitution does not say that only citizens who have reached age

211 These states are Alaska, Arizona, Florida, Georgia, Hawaii, Idaho, Iowa, Kansas, Louisiana, Maine, Michigan, Minnesota, Montana, Nebraska, New Hampshire, New York, North Carolina, Pennsylvania, Texas, Virginia, and West Virginia. See infra Appendix.

212 See supra Section III.A.

213 Tex. Const. art. VI, § 1(a)(1).

214 VA. Const. art. II, $\S 1$.

215 See Douglas, supra note 6, at 95.

216 See id. at 101-03.

217 Ky. Const. § 145. 
eighteen are qualified to vote in all elections. ${ }^{218}$ Those who are eighteen may vote in state elections, but the language does not explicitly preempt local jurisdictions from lowering that age for local elections because it does not couch the voter qualifications as restrictions. Colorado's constitution, which says, "Every citizen of the United States who has attained the age of eighteen years, has resided in this state for such time as may be prescribed by law, and has been duly registered as a voter if required by law shall be qualified to vote at all elections," is another example of a grant. ${ }^{219}$ The phrases "has attained," "has resided," and "has been duly registered" open the door to local expansions-they stipulate certain criteria to define the state's electorate but do not explicitly limit voting only to those who have satisfied these requirements. 220

State legislation also varies in listing voter qualifications as either a floor or a ceiling. Illinois law is an example of a floor, allowing local jurisdictions to go beyond the statewide rules: "Every person ... who is a citizen of the United States, of the age of 18 or more years is entitled to vote at such election for all offices and on all propositions." 221 An Illinois resident "is entitled" to vote in state elections if he or she meets the voter qualification requirements, but the textual formulation of the statute does not limit local jurisdictions from expanding those rules for local elections; other individuals also may be "entitled" to vote in local elections if the local rules so allow. In contrast, Minnesota law requires certain characteristics of all voters: "[A]n individual who meets the following requirements at the time of an election is eligible to vote. The individual must: (1) be 18 years of age or older; (2) be a citizen of the United States; and (3) maintain residence in Minnesota for 20 days immediately preceding the election."222 The word "must," in describing the voter qualifications, dictates these requirements for all voters in all elections in the state, placing a ceiling on localities that want to pass a more expansive rule. Advocates of local expansion must convince the state legislature to amend the law. Again, the policy arguments listed above-the history

218 In this context, courts should not necessarily apply the statutory construction expressio unius est exclusio alterius - or the inclusion of some things means the exclusion of others-under a substantive theory of democracy that favors voter inclusion. See, e.g., Richard L. Hasen, The Democracy Canon, 62 Stan. L. Rev. 69, 109-10 (2009).

219 Colo. Const. art. VII, $\S 1$ (LEXIS, LexisNexis through 2016 legislative session).

220 See Generation Citizen, supra note 86, at 17.

22110 ILl. COMP. STAt. 5/3-1 (2016), http://www.ilga.gov/legislation/ilcs/ilcs4.asp?DocName $=001000050 \mathrm{HArt} \% 2 \mathrm{E}+3 \&$ ActID $=170 \&$ ChapterID $=3 \&$ SeqStart $=11300000 \&$ SeqEnd $=12200000$.

222 Minn. Stat. § 201.014 (2016). 
of many voter expansions occurring at the local level, the fact of local control over elections, and a recognition that local governmental entities should be able to choose their own theory of democracy-should assist reform advocates in seeking to change the law.

In sum, many states list voter qualifications in their constitutions and statutes as "grants" (e.g., anyone who is eighteen may vote in state elections), as opposed to "restrictions" (e.g., one may not vote unless they are eighteen). Language that couches voting rights as a grant opens the door to local laws that go beyond these requirements for their own elections. States that have restrictions should reform their laws. In states that do not substantively and specifically limit local rules on the right to vote, however, municipalities should enact local voting laws to expand the franchise. As discussed below, courts should construe the provisions to allow for local voting laws where possible and should defer to local expansions of the franchise.

\section{Home Rule}

Home rule refers to the extent to which a state allows local jurisdictions to have local control. ${ }^{223}$ With home rule, municipalities can enact laws that affect their cities or towns, such as voter qualifications for local elections. If a state constitution or statute has not granted municipalities legal power through home rule, however, then local jurisdictions may not act independently of the state legislature.

Initially, cities and towns did not have much authority to enact their own laws. Under Dillon's Rule, local jurisdictions could pass only laws directly related to their municipal charter or laws that the state explicitly allowed, because "municipalities possessed only those powers indispensable to the purposes of their incorporation as well as any others expressly bestowed upon them by the state." 224

But states and localities became frustrated with the restrictive nature of Dillon's Rule, leading states to pass home rule provisions that gave local jurisdictions much broader authority to enact substantive rules. ${ }^{225}$ Early proponents perceived home rule as a means to prevent

223 Terrance Sandalow, The Limits of Municipal Power Under Home Rule: A Role for the Courts, 48 Minn. L. Rev. 643, 645 (1964).

224 Diller, supra note 176, at 1122-23 (citing 1 John F. Dillon, The Law of Municipal Corporations $\S 9$ b, at 93 (2d ed. 1873) ("[Municipalities] possess no powers or faculties not conferred upon them, either expressly or by fair implication, by the law which creates them . . ..")); see Hunter v. City of Pittsburgh, 207 U.S. 161, 177-79 (1907) (adopting Dillon's Rule).

225 See Diller, supra note 176, at 1124 (discussing the emergence of home rule "at the end of the nineteenth and beginning of the twentieth centuries"). 
the centralized state government from interfering in local affairs. ${ }^{226}$ The doctrine recognizes that local governments should have the power "to organize the local political entity, to establish its governing organs, their selection, their powers and their limits." 227

Traditional home rule doctrine classifies home rule provisions as either "imperio," which gives localities both the power to enact local rules and immunity from having to follow inconsistent state laws, or "legislative," which provides the power to localities but not the guarantee against state preemption. 228 Yet most courts considering local election laws have not drawn this distinction at all. ${ }^{229}$ Instead, they have tended to uphold local authority to enact local election rules regardless of whether the home rule doctrine comes from the state constitution or state statute and regardless of whether the home rule power is of the imperio or legislative form. ${ }^{230}$ As Professor Richard Briffault notes, "What really seems to matter is the judicial recognition that local control of local governance or politics is both of central importance to the local self-determination that is home rule while simultaneously posing little or no threat or cost to the localities or the state beyond local borders." ${ }^{231}$

The use of home rule authorization has not been consistent throughout the country, and "a patchwork of approaches to local authority" exists among the states. ${ }^{232}$ For example, California grants

226 See, e.g., Rodney L. Mott, Home Rule for AmericA's Cities 7 (1949) ("One of the major objectives of home rule is to prevent legislative interference with local government. During a large part of the nineteenth century, under the dominant theory of legislative supremacy, cities were considered to be merely creatures of the state legislature. . . Cities were completely subservient to legislative vagaries and whims . . . Legislative interference with cities tends to turn state legislatures into spasmodic city councils. Home rule, as a device for returning local business to the city, is the obvious remedy for these evils."). For an account of the home rule movement that suggests the story is more complicated and entailed both grants and limits on local power, see David J. Barron, Reclaiming Home Rule, 116 HARv. L. Rev. 2255 (2003).

227 City of La Grande v. Pub. Employes Ret. Bd., 586 P.2d 765, 767-68 (Or. 1978) (en banc).

228 See Briffault, Home Rule, supra note 174, at 19. See generally LynN A. BAKER, CLAYton P. Gillette \& David Schleicher, Local Government Law (5th ed. 2015); Richard Briffault \& Laurie Reynolds, Cases and Materials on State and Local GovernMENT LAW (7th ed. 2009).

229 See Briffault, Home Rule, supra note 174, at 19.

230 See id.

231 Id.

232 See Diller, supra note 176, at 1126. Indeed, some states grant home rule to counties but not cities, and vice versa. See Paul A. Diller, The City and the Private Right of Action, 64 STAN. L. REv. 1109, 1130 (2012) (noting that "within a state, home rule may vary between city and county - with one having more power than the other-as well as among different cities and among different counties"). 
fairly broad home rule power to its cities and towns, while Massachusetts does not. ${ }^{233}$ California's constitution provides that municipalities "may make and enforce all ordinances and regulations in respect to municipal affairs." 234 The California Constitution goes on to list explicitly "city elections" as a permissible subject of city charters. ${ }^{235}$ Thus, San Francisco's recent debate about lowering the voting age to sixteen falls directly within the grant of home rule that the state's constitution provides. ${ }^{236}$ By contrast, Massachusetts law requires the state legislature to approve any local voting rules. ${ }^{237}$

In some states, legislation explicitly grants authority to local jurisdictions to enact laws pertaining to local elections. Maryland's election code, for example, provides that except for Baltimore, state election law does not bind towns and cities if they choose to enact their own election rules; this is the very authority that Takoma Park and Hyattsville invoked to lower the voting age for their city elections. ${ }^{238}$ Similarly, Missouri law gives any city with a population over 400,000 the right to regulate its own elections. ${ }^{239}$ Thus, Kansas City, the only Missouri city with a population that high, may enact rules for its local elections that go beyond state voter qualifications. ${ }^{240}$

233 For a comprehensive discussion of the home rule potential to lower the voting age in every state, see Generation Citizen, supra note 86. See also infra Appendix.

234 CAL. Const. art. XI, § 5(a).

235 Id. $\S 5(\mathrm{~b})$.

236 Home rule authorization likely exists for local laws to lower the voting age in Arkansas, California, Colorado, Illinois, Maryland, Missouri (only Kansas City), New Jersey, New Mexico, Ohio, Oklahoma, Rhode Island, South Dakota, Washington, Washington, D.C., and Wisconsin. In other states, an explicit lack of home rule authority either forbids local voting laws or is not clear. See infra Appendix; see also Generation Citizen, supra note 86, at 19-21. Several states have statutes that contemplate local laws that allow nonresidents to vote in municipal elections, thereby providing home rule authority for this category of voter expansion. See supra note 141 and accompanying text. In addition, states may vary in their home rule authorization for cities versus counties. See Diller, supra note 232, at 1130.

237 Mass Const. amend. art. LXXXIX, § 8; Mass. Ann. Laws ch. 43B (LexisNexis 2016).

238 Md. Code Ann., Elec. Law § 2-202(a) (LexisNexis 2016) ("Except for the City of Baltimore, the provisions of this section do not apply to a municipal corporation in the State in which the municipal or charter elections are regulated by the public local laws of the State or the charter of the municipal corporation."); see supra Section II.A.

239 Mo. Rev. Stat. $\$ 122.650$ (2016) ("Full power and authority are hereby conferred on every city in this state which now has, or may hereafter have, more than four hundred thousand inhabitants, to provide for and regulate all elections for offices of and under such city and for the nomination of candidates for such offices; and such provision for and regulation of such elections may be effected either by charter provisions therefor adopted by the people of such city according to law, or ordinances therefor duly enacted, or by the people thereof under the power of initiative, if any, reserved in the charter of such city.").

240 See QuickFacts: Kansas City city, Missouri, U.S. Census Bureau, https://www.census. 
On the other end of the spectrum, some states expressly prohibit municipal action on local elections. For instance, Connecticut's home rule provision, which grants cities and towns the authority to pass local laws, contains an explicit exception for local rules about elections:

No provision of this chapter shall be deemed to empower any municipality ... to adopt a charter, charter amendments or home rule ordinance amendments which shall affect matters concerning qualification and admission of electors; duties and responsibilities of registrars of voters; duties and responsibilities of town clerks with respect to electors, voting and elections; forfeiture of electoral rights and restoration of the same; absentee voting; conduct of and procedures at elections; hours of voting; canvass of electors; preliminary, final and supplementary registry lists; warning of elections; election officials and their duties and responsibilities; election canvass and returns; election contests; corrupt practices; prohibited acts with respect to elections; nomination of candidates; adoption and amendment of party rules; primaries; and political parties and enrollment therein. ${ }^{241}$

A local rule expanding the franchise in Connecticut is therefore invalid under this provision. Proponents of local voting rights must convince the Connecticut legislature to repeal the law and broaden home rule power to include local election rules.

Some state laws, however, are not as explicit as Connecticut's. For instance, Indiana's home rule statute allows local governments to pass local laws, except if the conduct "is regulated by a state agency." ${ }^{242}$ Of course, the Indiana Secretary of State's Office is a "state agency" that regulates elections. Yet the Secretary of State does not promulgate voter qualifications. Moreover, the home rule provision is not explicit in making an exception to home rule power if a municipality dictates its own voter qualifications for its own local elections. Absent this specificity, a court should construe the home rule exception narrowly and the local jurisdiction's power to decide who constitutes its own electorate broadly. As Hans Linde, the influential Oregon Supreme Court Justice, noted, local governments have the authority to "decide upon the organization of their government and the scope of its powers" 243 - which, at its most basic and fundamental

gov/quickfacts/table/PST045216/2938000,2036000,2965000,00 [https://perma.cc/E46G-DJTA] (last visited May 30, 2017).

241 Conn. Gen. Stat. § 7-192a (West 2008).

242 Ind. Code $\$ 36-1-3-8(7)$ (2016).

243 City of La Grande v. Pub. Employes Ret. Bd., 576 P.2d 1204, 1208 (1978) (en banc). 
level, should also include the power to decide whether to go beyond the minimum national standards in defining who is part of the local electorate.

\section{Judicial Interpretation of Local Laws Expanding the Franchise}

A federal constitutional challenge to a local ordinance that expands voter access will likely fail. The Constitution sets a minimum standard for voting rights under the Equal Protection Clause and various other amendments that are specific to voting, ${ }^{244}$ but it does not say that states or localities are prohibited from going above that floor. A lawsuit that invokes a state constitution or statute, however, presents more difficulties for advocates of local voting laws. The key questions will be whether the state's law contains voter qualification limits that preempt local action and whether the state has granted municipalities home rule to enact local legislation, as discussed above. In deciding these disputes, an overarching principle should guide courts: if there is any room for interpretation, local laws that expand the franchise deserve deference, while local laws that restrict the franchise do not.

\section{a. Federal Constitutional Challenges}

Litigants who seek to invalidate a local law that expands the right to vote will likely fail when invoking the U.S. Constitution. ${ }^{245}$ The Constitution sets a baseline for voter qualifications, but there is nothing to suggest that local jurisdictions cannot expand beyond these rules. The Constitution first looks to state law for substantive voter qualifications, saying that eligible voters for Congress are those individuals who may vote for the state legislature. ${ }^{246}$ In addition, states and localities may not deny the right to vote to citizens on the basis of race, ${ }^{247}$ sex,${ }^{248}$ inability to pay a poll tax, ${ }^{249}$ or age if above eighteen. ${ }^{250}$ The bulk of federal constitutional protection for the right to vote comes from the Fourteenth Amendment's Equal Protection Clause. ${ }^{251}$

244 See U.S. Const. amends. XIV, XV, XIX, XXIV, XXVI.

245 Local governments are subject to the one person, one vote rule that requires equal population among districts, see Avery v. Midland Cty., 390 U.S. 474, 484-85 (1968), but expansions of the right to vote to certain groups are unlikely to implicate one person, one vote concerns because a local election affects only that municipality and not other parts of the state. The value of everyone's vote is the same within that jurisdiction.

246 U.S. Const. art. I, § 2; id. amend. XVII.

247 Id. amend. XV.

248 Id. amend. XIX.

249 Id. amend. XXIV.

250 Id. amend. XXVI.

251 See id. amend. XIV. 
As the Supreme Court has explained, "once the franchise is granted to the electorate, lines may not be drawn which are inconsistent with the Equal Protection Clause of the Fourteenth Amendment." 252 States must grant the right to vote to all eligible voters on equal terms. Yet in recent years, the Court has weakened federal constitutional protection for the right to vote in a series of cases that have adopted a balancing test for analyzing restrictions on the franchise. ${ }^{253}$ Regardless of this weaker judicial protection, however, a federal floor exists under which states and municipalities may not legislate.

But nothing in the text of the Constitution or the Supreme Court's caselaw prohibits a local jurisdiction from adopting more expansive voting rights. The Twenty-Sixth Amendment stipulates that states may not deny the right to vote to anyone aged eighteen or older, but it says nothing about lowering the voting age to sixteen or seventeen. A local law lowering the voting age is more expansive than the rule within the U.S. Constitution. As a district court explained, the Twenty-Sixth Amendment "provides that the right to vote cannot be denied on the basis of age to persons age eighteen or over, but it does not prohibit the states from setting a lower voting age." 254

Similarly, although the Constitution limits some forms of political participation to citizens-such as holding federal elected office ${ }^{255}$ - it does not include this qualification for voting. The U.S. Supreme Court has recognized that "citizenship has not in all cases been made a condition precedent to the enjoyment of the right of suffrage." ${ }^{256}$ The Court also has noted that, although the Constitution permits states to enact felon disenfranchisement laws, it does not require these restrictions, meaning that a state or locality could choose to allow felons to vote. ${ }^{257}$ Indeed, several states have re-enfranchised felons recently. ${ }^{258}$

252 Harper v. Va. Bd. of Elections, 383 U.S. 663, 665 (1966).

253 See Anderson v. Celebrezze, 460 U.S. 780, 789 (1983); Burdick v. Takushi, 504 U.S. 428, 434 (1992); Crawford v. Marion Cty. Election Bd., 553 U.S. 181, 189-90 (2008) (Stevens, J.); see also Joshua A. Douglas, (Mis)trusting States to Run Elections, 92 WAsH. U. L. REv. 553, 558 (2015) (criticizing the Court's undue deference to state interests in voting cases).

254 Day v. Robinwood W. Cmty. Improvement Dist., 693 F. Supp. 2d 996, 1007 n.12 (E.D. Mo. 2010).

255 See U.S. Const. art. I, § 2, cl. 2 (qualification of Representatives); id. art. I, § 3, cl. 3 (qualification of Senators); id. art. II, $\S 1$, cl. 5 (qualification of President).

256 Minor v. Happersett, 88 U.S. (21 Wall.) 162, 177 (1874); see also Kini, supra note 121, at 278 (advocating for local laws enfranchising noncitizens and noting that "a close examination of the Constitution and Supreme Court precedent on this issue suggests that any federal constitutional challenge to noncitizen voting would likely fail"); Raskin, supra note 133, at 1421 (explaining why noncitizen voting would not violate "principles of republicanism and one person-one vote, the various suffrage amendments, and the Naturalization Clause" (footnotes omitted)).

257 Richardson v. Ramirez, 418 U.S. 24, 54-56 (1974). 
A claim of vote dilution under the Equal Protection Clause is the other potential federal constitutional challenge to a local voting rule, particularly if a jurisdiction allows nonresidents to vote. The theory is that nonresident voters will "dilute" the strength of the votes of those who reside in the jurisdiction and have a true stake in local affairs. ${ }^{259}$ But courts have generally rejected these challenges using deferential rational basis review once the cities demonstrated that the nonresident voters had a "substantial interest" in the election. ${ }^{260}$ Therefore, vote dilution challenges are unlikely to succeed if the local jurisdiction has rationally decided that the new nonresident voters subject to the expansion have a sufficient stake in the city's governance. ${ }^{261}$

In addition, expanding voting rights in some localities but not others does not present a Bush v. Gore ${ }^{262}$ Equal Protection Clause problem-that "[h]aving once granted the right to vote on equal terms, the State may not, by later arbitrary and disparate treatment, value one person's vote over that of another." 263 There is no Bush v. Gore concern because, in a locality that expands voting rights, all voters are still treated the same. ${ }^{264}$ The rules apply only to local elections

258 See, e.g., Dave Boyer, McAuliffe Begins to Grant Voting Rights for Convicted Felons Individually After Court Ruling, WASH. Times (July 22, 2016), http://www.washingtontimes.com/ news/2016/jul/22/virginia-supreme-court-overturns-terry-mcauliffes-/; Megan Morris, Former Felons in Maryland Now Have Right to Vote, USA TodAy (Apr. 22, 2016, 4:05 PM), http:// www.usatoday.com/story/news/politics/elections/2016/2016/04/22/former-felons-maryland-nowhave-right-vote/83400610/; Sheryl Gay Stolberg \& Erik Eckholm, Virginia Governor Restores Voting Rights to Felons, N.Y. Times (Apr. 22, 2016), http://www.nytimes.com/2016/04/23/us/governor-terry-mcauliffe-virginia-voting-rights-convicted-felons.html.

259 See Briffault, supra note 10, at 399 ("The enfranchisement of those without some stake in the community would reduce the voice of community members in their own local affairs, interfere with their efforts to assure that their local government is responsive and accountable to their interests, and, ultimately, erode their ability to govern themselves."). See generally Amanda Mayo, Comment, Nonresident Vote Dilution Claims: Rational Basis or Strict Scrutiny Review?, 83 U. CHI. L. REv. 2213 (2016) (analyzing "the ways in which courts address . . nonresident vote dilution claims").

260 See Mayo, supra note 259, at 2236-40 (collecting cases). A "substantial interest" will often relate to local tax policy or school board issues.

261 See id. at 2241 (arguing that courts should consider "whether the border creating a resident/nonresident distinction artificially separates a unified political community"); see also Briffault, supra note 10, at 400 ("The expanded electorate cases indicate that the states will be given considerable discretion to extend the franchise to groups affected by a local government but not constitutionally entitled to vote in local elections. Such state decisions will be subject, however, to judicial review to protect the interest in local self-government of those residents most affected by the dilution that would result from the enfranchisement of those with a much smaller local stake.").

262531 U.S. 98 (2000) (per curiam).

263 Id. at $104-05$.

264 The biggest Bush v. Gore concern might come from a locality that expands voting rights 
and everyone's vote is equal within that locality. That is, within each governmental unit that holds elections for its officials, each vote has the same value as every other vote.

In sum, a court will likely dismiss a federal constitutional challenge to a local rule that expands voter access; nothing in federal law prevents states and localities, as laboratories and test tubes of democracy, from experimenting with right-to-vote provisions that grant greater access to the ballot.

\section{b. State Constitutional or Statutory Challenges}

Whether local rules on voting rights violate state constitutions or statutes presents a more serious question. A court facing a challenge to a local voting rights ordinance should engage in a two-part inquiry. First, does anything in the state constitution or state legislation explicitly forbid the local jurisdiction from expanding the franchise, either through voter qualification criteria or through a lack of home rule power? A court must discern whether the state constitution or legislation has spoken directly on the maximum qualifications for voters or on the authority of local jurisdictions to pass rules for their own elections. Put differently, does a state voter qualification law explicitly preempt local laws? And does the grant of home rule authority specifically exempt local jurisdictions from passing their own voting rules?

Second, assuming there is any room for a local jurisdiction to act, then a court should give deference to the municipal law if it expands the franchise. Municipalities have their own democratic structures and should dictate who may participate in their democratic processes. ${ }^{265}$ Local elections are particularly important because they are the closest form of democracy to the people and have the greatest effects on how individuals order their daily lives. Ultimately, courts should construe state constitutions, state legislation, and home rule provisions to allow local jurisdictions to pass rules that are more inclusive of voting rights.

If the state constitution or legislation describes a voter qualification as an explicit restriction, then a local jurisdiction may not expand

for nonresident property owners, especially if the number of votes is tied to the amount or value of the property owned in the locality. In that instance, challengers may have a stronger argument that expanding the right to vote for nonresident property owners treats individuals unequally in violation of the Equal Protection Clause. That said, courts so far have ruled that, because these provisions expand but do not restrict the right to vote, they do not lead to unlawful vote dilution. See supra notes 144-47 and accompanying text.

265 See Briffault, supra note 10, at 341 ("Local governments are often thought of as little democracies, providing fora for participation, deliberation and collective action concerning a wide range of policy matters."). 
on that rule. ${ }^{266}$ But if judicial interpretation will support a construction of the language as a grant, then the court should permit cities and towns to define their own electorate as a mechanism of local democracy. ${ }^{267}$ State courts already have upheld local election rules, even in the face of state laws on the same topic, as being "part of the core of local self-determination." 268 Other courts have ruled that state election laws are "models," and not mandates, that a local jurisdiction may adopt or alter pursuant to local concerns. ${ }^{269}$ Courts should similarly employ an interpretative canon that sustains a local voting rule unless state law creates a direct and unavoidable conflict. Put differently, courts should adopt a "clear statement" rule that requires a specific legislative declaration that the state intends to preempt local voting laws expanding the franchise. ${ }^{270}$ In the absence of this clear statement, courts should uphold local expansions of the right to vote. ${ }^{271}$

Courts should also adopt a clear statement standard for analyzing home rule provisions. More specifically, courts should interpret home rule statutes to allow localities to enact local laws that bring more voters into local democracy. Judges should reject a local rule that enhances voting rights only if the home rule provision explicitly demands it. That is, courts should uphold local election rules unless the state has directly exempted voting laws in its home rule authorization.

Some state courts have adopted a useful four-part test to determine whether home rule permits a local ordinance, which courts also can apply to local voting laws. Courts will ask:

First, does an actual conflict with state law exist? If there is no conflict between the charter city enactment and a state

266 See supra Section III.C.1.

267 This analysis is similar to what Professor Robert Williams has termed "negative implication" within state constitutions. A general statement in a state constitution implicitly allows more specific action on that subject. See Robert F. Williams, The Law of American State Constitutions 331 (2009).

268 See Briffault, Home Rule, supra note 174, at 24.

269 See id. at 25 (noting that some state courts have found that state election laws are simply "models unless the state expressly articulated an intent to preempt").

270 See id. at 25-26 (citing cases from New York and Texas that adopted a clear statement rule and upheld local election procedures).

271 Of course, requiring a "clear statement" might simply lead a state that wishes to preempt local voting expansions to pass explicit laws banning the local rules. But that is how our governmental structure is supposed to work. If proponents of local laws oppose these statewide efforts, they will simply need to convince their fellow state citizens to vote for legislators who will allow local voting rights. 
law, then there is no need for a court to determine whether the issue is a municipal affair or a statewide concern. Second, does the given activity "implicate" a municipal affair? Third, does the conflicting state law address a matter of statewide concern? Fourth, is the conflicting state law "reasonably related" and "narrowly tailored" to address the statewide concern?272

Based on the policy rationales discussed above, ${ }^{273}$ courts analyzing a local rule expanding the right to vote under this test should generally not find a conflict under the first prong. No conflict exists between a general state law on voter qualifications and a more specific local law that applies only to local jurisdictions, unless the state explicitly has preempted local voting rules under its substantive election laws or home rule authorization. Moreover, under the second prong, a local voting rule necessarily addresses a municipal affair-local democracy. Statewide voting rules-when they do not prohibit local action explicitly-implicate statewide, not municipal, democracy. There is no statewide concern if a town expands the right to vote for its own elections because that action has a predominantly local impact. Thus, unless a state law specifically dictates voter qualifications or takes away home rule authorization, courts using this test should find no conflict and therefore should sanction robust local authority to dictate the electorate for local elections. ${ }^{274}$

Deference for local action expanding the right to vote is warranted to vindicate the federalism ideals in local democratic governance. Cities have their own governmental structures, as well as ordinances, that bind local residents, so courts should allow these municipalities and their constituents to adopt a more expansive theory of democracy and representation. Cities might have particular local concerns that a larger electorate should address, such as vacation towns in which the entire community's economy depends on catering to nonresident property owners. Local voting rights and democratic representation are matters of local, not statewide, concern because these concepts go to the core of local governance. ${ }^{275}$ As one commenter ex-

272 Kini, supra note 121, at 288 (footnotes omitted) (quoting Johnson v. Bradley, 841 P.2d 990, 996 (Cal. 1992) (en banc)); see also Yang, supra note 135, at 75-76 (arguing for home rule provisions to allow local jurisdictions to enact rules allowing noncitizens to vote).

273 See supra Section III.A.

274 See Briffault, Home Rule, supra note 174, at 19 ("In other words, if it is a question of local political structure and there are no external effects and no state harm from intrastate variations, local innovations can prevail notwithstanding the conflict with state law.").

275 See May v. Town of Mountain Village, 969 P.2d 790, 794 (Colo. App. 1998) (upholding a 
plains, in justifying San Francisco's consideration of expanding the right to vote to noncitizens for school board elections:

San Francisco has a legitimate interest in fostering a more representative, responsive local school board that will take into account the needs of its large immigrant student population when making important educational policy decisions affecting San Francisco's public schools. The home rule doctrine provides a strong legal basis for upholding San Francisco's decision to enfranchise noncitizens in school board elections, despite contradictory state laws regarding voter qualifications. ${ }^{276}$

Stifling local experimentation and innovation is dangerous, especially when it comes to representative democracy. Some expansions of the right to vote have occurred initially through local laws. ${ }^{277}$ Courts should allow that expansion to continue. A groundswell of support may then spread across the country, forcing state legislatures and Congress to consider the issue. ${ }^{278}$ Courts should permit cities to act as "test tubes of democracy" unless a state law explicitly requires a contrary result. Furthermore, courts have historically deferred to local laws on the right to vote. ${ }^{279}$ Even more recently, state courts have upheld local innovations on election laws "either by determining that the local interest in local elections or the structure of local government outweighs the state interest behind the conflicting state statute or by concluding that the state did not mean to preclude local departures from state-prescribed models." 280 This same rationale should apply to all expansions of the right to vote.

If a local jurisdiction has decided that sixteen- and seventeenyear-olds, noncitizens, or nonresident property owners have a sufficient stake in local governance, then a court should not prevent that

Colorado town's decision to enfranchise nonresident property owners and explaining that "the qualification of voters in local and municipal elections is a matter of local, not statewide, concern").

276 Kini, supra note 121, at 292. In 2016, San Francisco voters adopted an ordinance to grant voting rights to noncitizens for school board elections. See Rong-Gong Lin II, San Francisco Measure to Allow Noncitizen Parents to Vote in School Board Elections Leading, L.A. Times (Nov. 9, 2016, 4:02 AM), http://www.latimes.com/nation/politics/trailguide/la-na-electionaftermath-updates-trail-san-francisco-measure-to-allow-1478692962-htmlstory.html [http:// perma.cc/27C5-TF2B].

277 See supra Parts I, II.

278 See Diller, supra note 176, at 1129 ("Once a city or a number of cities have put an issue on the nation's policy agenda, . . Congress or state legislatures may feel more compelled to address it.").

279 See supra notes 37-41 and accompanying text.

280 Briffault, Home Rule, supra note 174, at 3. 
expansion of the electorate. As Professor Diller explains, courts should apply a presumption against preemption for good-faith local policy experiments because "a good-faith policy experiment is a city's reasonable attempt to solve a social problem in a way that fairly internalizes the costs of the policy experiment, at least vis-à-vis other cities." ${ }^{281}$ Here, the social problem is the lack of citizen participation and voter turnout in local elections; the good-faith policy experiment is simply a municipality's decision to include more people in the electorate. In addition, allowing local jurisdictions to define the scope of local democracy and local representation can provide valuable information for future state or national debates about expanding the right to vote.

While deference is appropriate for expansions of the franchise, that same deference is inappropriate for laws that restrict voter access. ${ }^{282}$ Both federal and state laws set a floor for voter qualifications, such as the Twenty-Sixth Amendment's stipulation that no jurisdiction may deny the right to vote to anyone aged eighteen or older. ${ }^{283} \mathrm{~A}$ local rule that raises the voting age is obviously unconstitutional and no deference is warranted. Further, from a normative perspective, no societal good comes from local rules that restrict who may vote. Only entrenched majorities benefit from reduced voter rolls. ${ }^{284}$ Denying the right to vote to someone who otherwise should participate harms the ideal of democratic inclusion. ${ }^{285}$ Excluding these voters demeans their place in our democratic society and calls into question the very efficacy of that democracy. Restrictive rules also may impugn the democratic legitimacy of elected officials who might enjoy the support of only a minority of the population because others were shut out of the process. Moreover, incumbents might try to entrench themselves in

281 Diller, supra note 176, at 1170-71 (footnotes omitted).

282 See, e.g., Kramer v. Union Free Sch. Dist. No. 15, 395 U.S. 621, 627 (1969) (invalidating New York law that allowed only property owners and parents of school children to vote in school board elections).

283 U.S. CONST. amend. XXVI.

284 For a stark discussion of local voter purges and other voter suppression tactics in southern states, see Michael Wines, Critics See Efforts by Counties and Towns to Purge Minority Voters from Rolls, N.Y. Times (July 31, 2016), http://www.nytimes.com/2016/08/01/us/critics-seeefforts-to-purge-minorities-from-voter-rolls-in-new-elections-rules.html. The article highlights voter purges of African Americans in a small Georgia town, demonstrating poignantly why deference is inappropriate for voter restrictions.

285 See Hamilton, supra note 100, at 1479 (advocating for a "democratic principle of presumptive inclusion" by noting that "an individual's status as a legal subject of the government, and thus a member of the political community and one of 'the people,' presumptively entitles the individual to participate in the governance of a democratic system"). 
power by restricting the voting rights of members of groups that oppose them, warranting skepticism toward franchise-reducing rules. ${ }^{286}$

Of course, the opposite could be true as well: politicians might enfranchise new groups specifically because these new voters will likely support them, making voter expansion a means of incumbent protection. But politically motivated expansions of the franchise are less concerning than voter restrictions based on a norm of representative democracy that favors inclusivity. ${ }^{287}$ As discussed above, if increased participation is itself a desirable norm for a well-functioning representative democracy, then it should not matter if the underlying goal for the expansion was itself political. Thus, local voter expansions, even if done for political reasons, warrant judicial deference (if they are not discriminatory), while voter restrictions do not. Put differently, the threat of incumbency protection is a price we might have to pay for laws that expand voter access, but it is a price well worth it given the long-term benefits of increased participation to our concept of democracy. It is not necessarily entrenchment if new voters continue to support the politicians who helped give them the vote so long as the elections remain structurally fair.

Deferring to voter expansions but not limitations does not mean that a local jurisdiction could never pass a law that has the effect of restricting voter access. Perhaps a town decides to lower the voting age to sixteen, but then after a few elections realizes that the idea is not working as anticipated, so it wants to go back to a minimum voter age of eighteen. That jurisdiction could still change its voter qualifications and raise the voting age. To do so, however, the jurisdiction would have to satisfy heightened scrutiny, without any deference. The jurisdiction must have a strong enough reason to revert back to its prior, more restrictive rule. This test is similar to a nonretrogression principle that courts already use for Voting Rights Act claims. ${ }^{288}$ The anchor for this analysis, as applied to local expansions of suffrage, rests within the text of state constitutions in their explicit conferral of the right to vote. ${ }^{289}$ In essence, judicial deference should serve as a one-way ratchet: deference for local expansions; no deference, and

286 See Schleicher, supra note 172, at 248, 250 (advocating against judicial deference for local election laws).

287 See supra Section III.A.

288 See Michael J. Pitts, Rescuing Retrogression, 43 FLA. St. U. L. Rev. 741, 742, 751 n.51 (2016) (arguing that courts should apply the nonretrogression principle typically used for claims under now-defunct section 5 of the Voting Rights Act to claims under section 2).

289 See generally Douglas, supra note 6. 
heightened scrutiny, for local restrictions. ${ }^{290}$ Although a one-way ratchet for voter expansions could, in theory, act as a deterrent to experimentation itself, once a few courageous localities demonstrate the positive effect of broadening the right to vote for local democracy, others will surely follow suit even if they know it will be harder to repeal the law in the future. Moreover, this mode of judicial interpretation best comports with the history of expanded voting rights, the benefits of local experimentation, a theory of democracy that allows the people of a governmental entity to decide for themselves who should comprise the electorate, and a notion of inclusiveness as a democratic ideal.

\section{Practical Difficulties in Expanding Local Voter Qualification Rules}

The final potential hurdle for local expansions of the right to vote is more practical: how do we implement a system in which more voters can participate in local elections than in federal or statewide elections? For example, how can a jurisdiction easily and efficiently administer an election in which only those sixteen and older can vote for certain races (local elections), while those eighteen and older can vote for all offices (federal and state elections)?

Many cities and towns already hold their local elections on different days than the national or state elections. ${ }^{291}$ For instance, Takoma Park, Maryland, had its most recent city election in an off-year (2015), so only city races-in which sixteen- and seventeen-year-olds could vote-were on the ballot. ${ }^{292}$ Given that many places already hold separate local elections on different days, voter expansions for these elections present no significant administrative hurdles. However, having local elections on different days or in odd-numbered years dampens turnout. ${ }^{293}$ If the policy goal is to expand the electorate and encourage greater participation, then using a system that might decrease turnout is contrary to that ideal. Further, if a jurisdiction does not already hold

290 See supra note 143 and accompanying text (discussing Delaware's use of a one-way ratchet for nonresident voting expansions).

291 See, e.g., Sarah F. Anzia, Timing and Turnout: How Off-Cycle Elections Favor Organized Groups 2 (2014).

292 See Generation Citizen, Lowering the Voting Age for Local Elections in TAKoma PARK And Hyattsville, MD 4 (2016), http://vote16usa.org/wp-content/uploads/2016/ 10/Final-MD-Case-Study.pdf; Results of Past Elections, CITY OF TAKOMA PARK, https://takoma parkmd.gov/results-of-past-elections/ [https://perma.cc/RK8T-9446] (last visited May 31, 2017).

293 See Anzia, supra note 291, at 2-3; Zoltan L. Hajnal, America's Uneven Democ racy: Race, Turnout, and Representation in City Politics 159 (2010) (finding that "election timing is the most important factor in explaining local voter turnout"). 
local elections on different days, then adding additional Election Days is cost prohibitive.

The better approach, then, is to use election technology to facilitate this change. The technology already exists and is in use to make it easy to implement a system that provides individuals with the option to vote for only certain offices depending on their residence or party affiliation. For example, on primary day, local precincts will give a voter only the ballot for the party in which he or she is registered (in states that limit primary voters to party members or independents). ${ }^{294}$ Similarly, many jurisdictions provide for early voting at a central county clerk's office, with the electronic voting machine showing only the races for the voter's particular precinct. ${ }^{295}$ Thus, electronic machines exist that will allow voters to cast ballots for only the offices for which state law deems them eligible. This same technology could differentiate between voters using other voter qualifications, such as age or citizenship, and then display only local offices to voters eligible to vote solely in local races.

Moving away from precinct-based voting on Election Day also would solve this problem. Some jurisdictions use a system in which individuals need not vote in person at their home precincts. Regardless of where they vote, the electronic voting machines show only the races for their home residence. ${ }^{296}$ In Doña Ana County, New Mexico, election officials successfully implemented a system of non-precinctbased voting; instead of having to go to their home precinct, voters may use any of the thirty-nine Voting Convenience Centers in the county. ${ }^{297}$ They can vote at the voting center closest to their work, for example, and the voting machine will display only those elections in which they are eligible to vote based on their home address. The same system can work for local expansions of the right to vote. For instance, in a jurisdiction that has lowered the voting age, the voter's registra-

294 See, e.g., Primaries, FAIRVoTE, http://www.fairvote.org/primaries\#open_and_closed_pri maries (last visited May 31, 2017).

295 See, e.g., Office of the Tex. Sec'y of State, How to Vote, VoteTexas.gov, http:// www.votetexas.gov/voting/how.html [https://perma.cc/WZ3A-Z5H8] (last visited May 31, 2017) (discussing use of electronic voting machines); Office of the Tex. Sec'y of State, Where to Vote, VoteTexas.gov, http://www.votetexas.gov/voting/where.html [https://perma.cc/968X-NS47] (last visited May 31, 2017) ("Registered and eligible voters may vote at ANY early voting location located in the county of residence. Whether you are at home, work or out running errands, you will be able to find a polling place near you.").

296 See Brian Heaton, Tech Helps End Precinct Voting in New Mexico County, Gov'T TECH. (June 27, 2012), http://www.govtech.com/e-government/Tech-Helps-End-Precinct-Votingin-New-Mexico-County.html.

297 Id. 
tion file will include both the address and age of the voter, thereby dictating which races the ballot will display. A voter who is sixteen would see only the ballot for the local races; a voter who is eighteen would see all offices.

Jurisdictions with mail-in voting, such as Colorado, Oregon, and Washington, ${ }^{298}$ similarly use technology to differentiate between voters. These states mail to voters a ballot that lists only the races specific to each voter, so counties in these states could incorporate other eligibility criteria if the jurisdiction expands the right to vote for local offices. Alternatively, poll workers at precincts could simply have a separate ballot available for the local offices. For instance, a sixteenyear-old who shows up to vote will receive only that ballot; all voters eighteen years and older will receive that ballot along with the ballot containing the other offices for which they may vote.

If a city within a particular county has expanded the right to vote only for city elections, and yet the larger county runs the election itself, then there are additional issues of election administration to consider. Yet voting technology can still fix this problem, producing a different ballot for eligible voters in the city. To be sure, the county election officials would have to fine-tune the election apparatus, but that is relatively simple through voting technology, and is feasible even in counties using traditional paper ballots.

In sum, practical challenges exist, but they simply require thought and experimentation to create a system that allows jurisdictions to broaden the electorate for local elections. Technology already facilitates differentiation among voters based on their eligibility to vote for certain offices, so increased use of that technology can mitigate any implementation concerns when a locality expands the right to vote.

\section{CONCLUSION}

Strong policy arguments support an expansion of the right to vote for local offices. History shows that some individuals initially gained the right to vote through municipal ordinances. Enhanced local voting rights will produce a more representative local government, create a habit of voting for various groups such as younger voters that will ameliorate low turnout, and strengthen local democracy.

In some states, supporters of local voting rules must pass a state constitutional amendment or legislative fix. These states should

298 See Absentee and Early Voting, Nat'L Conf. St. Legislatures (Mar. 20, 2017) http:// www.ncsl.org/research/elections-and-campaigns/absentee-and-early-voting.aspx. 
change their laws to give municipalities a say in who can vote for local offices. In states where municipalities already have more control over their elections, any new voting rules may result in legal challenges. Courts should defer to local laws that expand the franchise, while training a more skeptical eye on voter restrictions. This deference best comports with a notion of democracy that favors inclusivity and permits local jurisdictions to experiment with different forms of representation. Technology can solve any issues of implementation.

The time is ripe, then, for every jurisdiction in the United States to expand the local electorate-for sixteen- and seventeen-year-olds, noncitizens (who are lawful permanent residents), nonresident property owners, felons, or anyone else that the local population believes has a sufficient tie to the community, stake in local governance, and cognitive ability. Local expansions of the right to vote will help to improve our democracy by including more people in the democratic process. 


\section{Appendix: Possibility of Local Laws Expanding the Right to Vote in the Fifty States (And D.C.) ${ }^{299}$}

A * signifies that the rule is particularly open to legal interpretation or the law is otherwise unclear. Further explanation is available in the footnotes. 300

\begin{tabular}{|c|c|c|c|c|c|c|}
\hline State & $\begin{array}{l}\text { State Const. } \\
\text { Impediment- } \\
\text { Voter } \\
\text { Qualifications } \\
\end{array}$ & $\begin{array}{l}\text { State Legislative } \\
\text { Impediment- } \\
\text { Voter Qualifica- } \\
\text { tions } 301 \\
\end{array}$ & $\begin{array}{l}\text { State Const. } \\
\text { Impediment- } \\
\text { Lack of Home } \\
\text { Rule }^{302}\end{array}$ & $\begin{array}{l}\text { State Legislative } \\
\text { Impediment- } \\
\text { Lack of Home } \\
\text { Rule }^{303} \\
\end{array}$ & $\begin{array}{l}\text { Specific Statute } \\
\text { Allows } \\
\text { Localities to } \\
\text { Enfranchise } \\
\text { Nonresidents in } \\
\text { Certain } \\
\text { Elections } \\
\end{array}$ & $\begin{array}{l}\text { No Clear } \\
\text { Impediments }\end{array}$ \\
\hline Alabama & & & $X^{304}$ & $\mathrm{X}^{305}$ & & \\
\hline Alaska & & $\mathrm{X}^{306}$ & & $X^{307}$ & & \\
\hline Arizona & $\mathrm{X}^{308}$ & & & & $\mathrm{X}^{309}$ & \\
\hline
\end{tabular}

299 Thanks to my research assistant Grant Sharp for compiling the initial version of this Appendix and to the organization Generation Citizen for its helpful research.

300 Editors' note: Sources below are cited with both the preferred official reporter and a parallel citation to the statutory text on each state's website. The editors substantiated the sources using the online materials.

301 This column focuses on state statutes that dictate substantive voter qualifications. The state also may have procedural rules on voter registration that may be relevant.

302 This chart does not differentiate between "imperio" and "legislative" forms of home rule given that most state courts have not drawn this distinction in election law cases. See supra notes 228-31 and accompanying text.

303 Any attempt to categorize states based on their home rule doctrines is bound to involve some discretion because the varying rules that come from state constitutions and state statutes involve differing local governmental structures. There may also be variation between cities and counties. See Diller, supra note 232, at 1130. This chart presents the data based on the language from state constitutions and state statutes. Judicial decisions in these states may shed additional light.

304 Alabama's constitution and code phrase the right to vote as a grant. See Ala. Const. art. VIII, §§ 177-178; ALA. CoDE § 17-3-30 (2017), http://alisondb.legislature.state.al.us/alison/ codeofalabama/1975/17-3-30.htm. But the Alabama Constitution limits home rule. See AlA. Const. art. IV, § 105.

305 Alabama election law provides that the state's election code governs municipal elections. AlA. CODE $§ 17-1-1$ (2017), http://alisondb.legislature.state.al.us/alison/codeofalaba ma/1975/17-1-1.htm.

306 Alaska's constitution phrases the right to vote as a grant. See Alaska Const. art. V, § 1. Yet Alaska Stat. § 29.26 .050 (2017), http://www.legis.state.ak.us/basis/statutes.asp\#29.26 .050 , grants citizens the right to vote "only if" they meet the requirements of ALASKA STAT. $\S 15.05 .010$ (2017), http://www.legis.state.ak.us/basis/statutes.asp\#15.05.010, phrasing the right to vote as a restriction.

307 Alaska's home rule law prohibits municipalities from altering voter qualifications. Alaska Stat. § 29.10.200(25) (2017), http://www.legis.state.ak.us/basis/statutes.asp\#29.10.200.

308 Arizona's constitution phrases the right to vote as a restriction. See ArIz. Const. art. VII, § 2 ("No person shall be entitled to vote . . . unless" they meet certain qualification standards). The state's election code, however, phrases the right to vote as a grant. See ArIz. Rev. Stat. Ann. § 16-101 (2017), http://www.azleg.gov/viewdocument/?docName=http://www .azleg.gov/ars/16/00101.htm.

309 Ariz. Rev. Stat. Ann. § 48-404 (2017), http://www.azleg.gov/viewdocument/?doc Name=http://www.azleg.gov/ars/48/00404.htm. 


\begin{tabular}{|l|l|l|l|l|l|l|}
\hline & $\begin{array}{l}\text { State Const. } \\
\text { Impediment- } \\
\text { Voter } \\
\text { Qualifications }\end{array}$ & $\begin{array}{l}\text { State Legislative } \\
\text { Impediment- } \\
\text { Voter Qualifica- } \\
\text { tions 301 }\end{array}$ & $\begin{array}{l}\text { State Const. } \\
\text { Impediment- } \\
\text { Lack of Home } \\
\text { Rule } 302\end{array}$ & $\begin{array}{l}\text { Specific Statute } \\
\text { Allows } \\
\text { Localities to } \\
\text { Impediment- } \\
\text { Lack of Home } \\
\text { Rule303 }\end{array}$ & $\begin{array}{l}\text { Nonresidents in } \\
\text { Certain } \\
\text { Elections }\end{array}$ & $\begin{array}{l}\text { No Clear } \\
\text { Impediments }\end{array}$ \\
\hline Arkansas & & & & & $\mathrm{X}^{310}$ & $\mathrm{X}^{311}$ \\
\hline California & & & & $\mathrm{X}^{312}$ & $\mathrm{X}^{313}$ \\
\hline Colorado & & & & $\mathrm{X}^{314}$ & $\mathrm{X}^{315 *}$ \\
\hline Connecticut & & & & & & \\
\hline
\end{tabular}

310 Ark. Code AnN. § 14-123-302 (2017) (Arkansas's online code is maintained by Lexis and does not allow for direct links to individual provisions, but the full code is available at http:// www.lexisnexis.com/hottopics/arcode/Default.asp).

311 Arkansas's constitution and code phrase the right to vote as a grant. See Ark. Const. art. III, § 1; Ark. Code AnN. § 7-1-101(33) (2017). Arkansas also provides municipalities with broad home rule powers. See Ark. Const. amend. LV, § 1; Ark. Code Ann. § 14-42-307 (2017).

312 CAL. Elec. CODE $\$ 12286$ (West 2017), http://leginfo.legislature.ca.gov/faces/codes_dis playSection.xhtml?sectionNum=12286\&lawCode=ELEC.

313 California's constitution and code phrase the right to vote as a grant. See CAL. Const. art. II, § 2; CAL. ELEC. CODE $\$ 2000$ (West 2017), http://leginfo.legislature.ca.gov/faces/ codes_displaySection.xhtml?sectionNum=2000\&lawCode=ELEC. The state constitution confers upon municipalities broad home rule power to govern "municipal affairs." CAL. Const. art. XI, $\S 5$ (a). Caselaw supports the proposition that elections are municipal affairs, thus granting municipalities the power to expand voter qualifications. See Socialist Party v. Uhl, 103 P. 181, 186 (Cal. 1909). The state's election code includes some requirements regarding the date of holding local elections but does not speak to voter qualifications in local elections. CAL. ELEC. CODE $§ \S 1300-1304$ (West 2017), http://leginfo.legislature.ca.gov/faces/codes_displaySection. xhtml? sectionNum=1300\&lawCode=ELEC. The combination of these laws gives California municipalities the authority to expand voter qualifications.

314 Colo. Rev. Stat. §§ 37-26-103, 37-41-104(2), 37-42-106(2) (2017) (Colorado's online code is maintained by Lexis and does not allow for direct links to individual provisions, but the full code is available at http://www.lexisnexis.com/hottopics/colorado/).

315 Colorado's constitution and laws phrase the right to vote as a grant. Colo. Const. art. VII, § 1; Colo. Rev. Stat. § 1-2-101 (2017). But Colorado's election code includes a specific provision on voter qualifications for municipal elections, suggesting that cities and towns cannot expand beyond the qualifications listed in this statute. Colo. Rev. Stat. § 31-10-201 (2017). Yet the Colorado Constitution gives charter cities broad power to shape their own election procedures. See Colo. Const. art. XX, § 6. Moreover, state law says that the municipal election code does not apply to cities and towns that have home rule. Colo. Rev. Stat. § 31-10-1539 (2017). Thus, the state law dictating voter qualifications for municipal elections likely does not apply if a city has home rule authority. See May v. Town of Mountain Village, 969 P.2d 790, 794 (Colo. App. 1998) (ruling that a town could allow nonresident property owners to vote in local elections under the state's home rule authorization).

316 Although Connecticut's constitution and code phrase the right to vote as a grant, state legislation forbids municipalities from altering the qualifications of voters. See Conn. Const. art. VI, § 1; Conn. Gen. Stat. § 7-6 (2017), https://www.cga.ct.gov/current/pub/chap_090.htm\#sec_76; Conn. Gen. Stat. § 7-192a (2017), https://www.cga.ct.gov/current/pub/chap_099.htm\#sec_7$192 \mathrm{a}$. 


\begin{tabular}{|l|l|l|l|l|l|l|}
\hline & $\begin{array}{l}\text { State Const. } \\
\text { Impediment- } \\
\text { Voter } \\
\text { Qualifications }\end{array}$ & $\begin{array}{l}\text { State Legislative } \\
\text { Impediment- } \\
\text { Voter Qualifica- } \\
\text { tions } 301\end{array}$ & $\begin{array}{l}\text { State Const. } \\
\text { Impedimen- } \\
\text { Lack of Home } \\
\text { Rule } 302\end{array}$ & $\begin{array}{l}\text { Specific Statute } \\
\text { Allows } \\
\text { Localities to } \\
\text { Impediment- } \\
\text { Lack of Home } \\
\text { Rule } 303\end{array}$ & $\begin{array}{l}\text { Nonresidents in } \\
\text { Certain } \\
\text { Elections }\end{array}$ & $\begin{array}{l}\text { No Clear } \\
\text { Impediments }\end{array}$ \\
\hline Delaware & & & & $\mathrm{X}^{317}$ & $\mathrm{X}^{318}$ & \\
\hline Florida & & $\mathrm{X}^{319}$ & & & & \\
\hline Georgia & & $\mathrm{X}^{320}$ & & $\mathrm{X}^{321}$ & & \\
\hline Hawaii & & $\mathrm{X}^{322}$ & & $\mathrm{X}^{323}$ & & \\
\hline Idaho & & $\mathrm{X}^{324 *}$ & & & & $\mathrm{X}^{325}$ \\
\hline Illinois & & & & & \\
\hline
\end{tabular}

317 Delaware's constitution and code phrase the right to vote as a grant. See DeL. Const. art. V, § 2; Del. Code AnN. tit. 15, § 7543 (2017), http://delcode.delaware.gov/title15/c075/sc03/ index.shtml. However, Delaware's code forbids municipalities from changing voter qualifications. Del. Code Ann. tit. 22, § 835(a)(3) (2017), http://delcode.delaware.gov/title22/ c008/sc06/index.shtml.

318 Del. Code Ann. tit. 16, § 1402(a)(3) (2017), http://delcode.delaware.gov/title16/c014/ index.shtml.

319 Florida's constitution phrases the right to vote as a grant. See Fla. Const. art. VI, § 2 . However, Florida's code phrases the right to vote as a restriction. See Fla. Stat. § 97.041 (2017), http://www.leg.state.fl.us/statutes/index.cfm?App_mode=display_Statute\&Search_String $=\& U R L=0000-0099 / 0097 /$ Sections/0097.041.html. Florida municipalities generally have home rule authority "except as otherwise provided by law," meaning that there would be no home rule impediment if the state amended its substantive voter qualification provision. See FLA. Const. art. VIII, § 2(b); FLA. StAT. § 166.021(1) (2017), http://www.leg.state.fl.us/Statutes/index.cfm? App_mode=display_Statute $\&$ Search_String=\&URL=0100-0199/0166/Sections/0166.021.html.

320 Georgia's constitution phrases the right to vote as a grant. See GA. Const. art. II, § 1, para. 2. However, Georgia's code phrases the right to vote as a restriction. See GA. Code Ann. $\S 21-2-216$ (2017) (Georgia's online code is maintained by Lexis and does not allow for direct links to individual provisions, but the full code is available at http://www.lexisnexis.com/hottopics /gacode/Default.asp).

321 Georgia's home rule statute forbids municipalities from changing voting procedures, which presumably would include voter qualifications. GA. CODE AnN. § 36-35-6(a)(1) (2017).

322 Hawaii's constitution phrases the right to vote as a grant. See Haw. Const. art. II, § 1 . However, Hawaii's code phrases the right to vote as a restriction. See Haw. Rev. Stat. § 11-11 (2017), http://www.capitol.hawaii.gov/hrscurrent/Vol01_Ch0001-0042F/HRS0011/HRS_00110011.htm.

323 Hawaii's code states that municipalities cannot alter election procedures for any election held in the state, which likely includes voter qualifications. See Haw. Rev. Stat. § 11-3 (2017), http://www.capitol.hawaii.gov/hrscurrent/Vol01_Ch0001-0042F/HRS0011/HRS_0011-00 03.htm.

324 Idaho's constitution phrases the right to vote as a grant. IDAho Const. art. VI, § 2 . However, Idaho's code states that "[n]o elector shall be permitted to vote if . . disqualified" by the voting requirements in the state's constitution. IDAHO CODE $\$ 34-403$ (2017), https://legisla ture.idaho.gov/statutesrules/idstat/Title34/T34CH4/SECT34-403/. Yet the Idaho Constitution only "disqualifies" felons, see IDAHo CONST. art. VI, $\S 3$, meaning that judicial interpretation of the statute might allow municipalities to extend voting rights to other groups. Moreover, Idaho's constitution grants municipalities the power to enact regulations that are not in conflict with the general laws of Idaho. IDAho Const. art. XII, §2. This suggests that, so long as the "disqualified" provision applies only to felons, Idaho municipalities enjoy home rule power to expand voter access to other constituencies besides felons.

325 Illinois's constitution and code phrase the right to vote as a grant. See Ill. Const. art. III, § 1; 10 Ill. Comp. Stat. 5/3-1 (2017), http://www.ilga.gov/legislation/ilcs/fulltext.asp?Doc 


\begin{tabular}{|l|l|l|l|l|l|l|}
\hline & $\begin{array}{l}\text { State Const. } \\
\text { Impediment- } \\
\text { Voter } \\
\text { Qualifications }\end{array}$ & $\begin{array}{l}\text { State Legislative } \\
\text { Impediment- } \\
\text { Voter Qualifica- } \\
\text { tions } 301\end{array}$ & $\begin{array}{l}\text { State Const. } \\
\text { Impediment- } \\
\text { Lack of Home } \\
\text { Rule 302 }\end{array}$ & $\begin{array}{l}\text { Specific Statute } \\
\text { Stlows } \\
\text { Localities to } \\
\text { Impediment- } \\
\text { Lack of Home } \\
\text { Rule303 }\end{array}$ & $\begin{array}{l}\text { Enfranchise } \\
\text { Nonresidents in } \\
\text { Certain } \\
\text { Elections }\end{array}$ & $\begin{array}{l}\text { No Clear } \\
\text { Impediments }\end{array}$ \\
\hline Indiana & & & & $\mathrm{X}^{326 *}$ & & \\
\hline Iowa & & $\mathrm{X}^{327}$ & & & & \\
\hline Kansas & & $\mathrm{X}^{328}$ & & & & \\
\hline Kentucky & & & & $\mathrm{X}^{329 *}$ & & \\
\hline Louisiana & & & & & \\
\hline
\end{tabular}

Name $=001000050$ K3-1. In regard to home rule, Illinois's constitution grants municipalities broad authority. See ILl. Const. art. VII, § 6.

326 The Indiana Constitution and Code both phrase the right to vote as a grant. See IND. Const. art. II, § 2; IND. CODE § 3-7-13-1 (2017), http://iga.in.gov/static-documents/6/9/d/6/ 69d60e63/TITLE3_AR7_ch13.pdf. But Indiana's code prohibits municipalities from legislating on conduct that a state agency already regulates. IND. CoDE $\S 36-1-3-8(a)(7)$ (2017), http:// iga.in.gov/static-documents/c/5/d/3/c5d3a46f/TITLE36_AR1_ch3.pdf. Considering that the Indiana Secretary of State regulates elections, municipalities would likely be unable to expand voter qualifications. About the Office, IN.gov: SeCretary St., http://www.in.gov/sos/2362.htm (last visited June 3,2017). That said, a court could find that the state agency does not necessarily regulate voter qualifications for local elections, opening the door to local laws on this issue.

327 Although Iowa's constitution phrases the right to vote as a grant, the election code phrases it as a restriction. See IowA Const. art. II, § 1; IowA CodE § 48A.5 (2017), https:// www.legis.iowa.gov/docs/code/2016/48A.pdf. Iowa's constitution grants municipalities "home rule power and authority, not inconsistent with the laws of the general assembly, to determine their local affairs and government," meaning that there would be no home rule impediment if Iowa changed its substantive election law. IowA CONST. art. III, § 38A.

328 Although Kansas's constitution phrases the right to vote as a grant, the election code phrases it as a restriction. See Kan. Const. art. V, § 1; Kan. Stat. AnN. § 25-2306 (2017), http:// kslegislature.org/li/m/statute/025_000_0000_chapter/025_023_0000_article/025_023_0006_section/ 025_023_0006_k.pdf. Kansas's municipalities have broad home rule authority. See KAN. Const. art. XII, § 5 .

329 The Kentucky Constitution phrases the right to vote as a grant, although it denies voting rights to felons. See Ky. Const. $\$ 145$. The state election code does not mention voter qualifications. Regarding home rule, Kentucky allows municipalities to take action that is in furtherance of a public purpose. Ky. Rev. Stat. Ann. \$ 82.082 (West 2017), http:// www.lrc.ky.gov/statutes/statute.aspx?id=25036. However, Kentucky does not confer home rule authority where "there is a comprehensive scheme of legislation on the same general subject." Id. The state has an election code, but state law does not include restrictions on voter qualifications. The question remains, then, whether the election code itself is a "comprehensive scheme" on this issue given that it says nothing about voter qualifications. Although technically an open question, the reasoning of a recent Kentucky Supreme Court decision, which invalidated a Louisville minimum wage ordinance that went beyond the state's minimum wage law, casts doubt on the ability of Kentucky municipalities to enact their own election rules given that the state has a detailed election code. See Ky. Rest. Ass'n v. Louisville/Jefferson Cty. Metro Gov't, 501 S.W.3d 425, 430 (Ky. 2016) (explaining that "express preemption is not required when the General Assembly has enacted a comprehensive statutory scheme" on a topic).

330 Louisiana's constitution phrases the right to vote as a grant, but the election code phrases it as a restriction, most explicitly with respect to age. See LA. Const. art. I, § 10; LA. StAt. Ann. § 18:101 (2017), https://legis.la.gov/Legis/Law.aspx?d=81242. Louisiana's constitution allows localities to adopt home rule charters. See LA. Const. art. VI, § 5. 


\begin{tabular}{|c|c|c|c|c|c|c|}
\hline State & $\begin{array}{l}\text { State Const. } \\
\text { Impediment- } \\
\text { Voter } \\
\text { Qualifications } \\
\end{array}$ & $\begin{array}{l}\text { State Legislative } \\
\text { Impediment- } \\
\text { Voter Qualifica- } \\
\text { tions } 301 \\
\end{array}$ & $\begin{array}{l}\text { State Const. } \\
\text { Impediment- } \\
\text { Lack of Home } \\
\text { Rule }^{302} \\
\end{array}$ & $\begin{array}{l}\text { State Legislative } \\
\text { Impediment- } \\
\text { Lack of Home } \\
\text { Rule }^{303} \\
\end{array}$ & \begin{tabular}{|l|} 
Specific Statute \\
Allows \\
Localities to \\
Enfranchise \\
Nonresidents in \\
Certain \\
Elections \\
\end{tabular} & \begin{tabular}{|l} 
No Clear \\
Impediments
\end{tabular} \\
\hline Maine & & $\mathrm{X}^{331}$ & & $\mathrm{X}^{332}$ & & \\
\hline Maryland & & & & & & $\mathrm{X}^{333}$ \\
\hline Massachusetts & & & & $\mathrm{X}^{334}$ & & \\
\hline Michigan & & $\mathrm{X}^{335}$ & & & & \\
\hline Minnesota & $\mathrm{X}^{336}$ & $\mathrm{X}^{337}$ & & $\mathrm{X}^{338 *}$ & & \\
\hline Mississippi & & & & $\mathrm{X}^{339}$ & & \\
\hline
\end{tabular}

331 Maine's constitution phrases the right to vote as a grant. See ME. Const. art. II, § 1 . However, the state's election code phrases the right to vote as a restriction. See ME. StAt. tit. 21A, § 111 (2017), http://legislature.maine.gov/statutes/21-A/title21-Asec111.html.

332 Although Maine's constitution grants broad home rule powers, its election code expressly preempts municipalities from changing voter qualifications from those the state has set. See Me. Const. art. VIII, pt. II, § 1; ME. StAt. tit. 30-A, § 2501 (2017), http://legislature. maine.gov/statutes/30-A/title30-Asec2501.html.

333 Maryland's constitution and code phrase the right to vote as a grant. See MD. Const. art. I, § 1; MD. CodE AnN., Elec. LAw § 3-102 (LexisNexis 2017), http://mgaleg.maryland.gov/ 2017RS/Statute_Web/gel/3-102.pdf. Maryland's election code expressly states that municipalities, except for Baltimore, may govern their own elections. ELEC. § 2-202, http://mgaleg.maryland. gov/2017RS/Statute_Web/gel/2-202.pdf.

334 The Massachusetts Constitution does not explicitly mention voter qualifications, although it says that the Commonwealth's "inhabitants" shall "have an equal right to elect officers." MAss. Const. pt. I, art. IX. Massachusetts law phrases the right to vote as a grant, with an exception for felons. See MAss. GEN. LAws ch. 51, § 1 (2017), https://malegislature.gov/Laws/ GeneralLaws/PartI/TitleVIII/Chapter51/Section1. Municipalities theoretically have home rule authority under state law to regulate their own elections, but they must go through an extensive process to amend their charter, which includes gaining legislative approval. See Mass. Const. amend. art. LXXXIX, § 8; MAss. GEN. LAws ch. 43B (2017), https://malegislature.gov/Laws/ GeneralLaws/PartI/TitleVII/Chapter43B.

335 Michigan's constitution phrases the right to vote as a grant, but Michigan's election code phrases the right to vote as a restriction. See Мich. Const. art. II, § 1; Мich. Comp. Laws $\S 168.492$ (2017), http://www.legislature.mi.gov/(S(ecw2v0jr15hffhsrdiljmqoh))/mileg.aspx? page=getobject\&objectname=mcl-168-492. Michigan's home rule statute provides, "No provision of any city charter shall conflict with or contravene the provisions of any general law of the state." Мiсн. СомP. Laws $\$ 117.36$ (2017), http://www.legislature.mi.gov/(S(sb1i1553z 2n0w0e1wlvomqmh))/mileg.aspx?page=getObject\&objectName=MCl-117-36.

336 Although Minnesota's constitution initially phrases the right to vote as a grant, it subsequently states that if a person does not meet the "above requirements," that person "shall not be entitled or permitted to vote at any election in this state." MinN. Const. art. VII, § 1.

337 Minnesota's law lists several requirements for voters, including: aged eighteen or older, citizen of the United States, and resident of the state for at least twenty days before the election. Minn. STAт. § 201.014 (2017), https://www.revisor.mn.gov/statutes/?id=201.014.

338 Minnesota's election code applies to municipal elections, except where a "statutory and home rule charter" city regulates the conduct of local elections in its charter. MinN. STAT. $\S 205.02$ (2017), https://www.revisor.mn.gov/statutes/?id=205.02. Thus, it appears that if a locality provides, in its charter, the manner of holding local elections, then the state statute saying that state law regulates municipal elections does not apply. Judicial interpretation of this provision may be helpful.

339 Mississippi's constitution and law phrase the right to vote as a grant (except for felons and those adjudicated mentally incompetent). See Miss. Const. art. XII, § 241; Miss. CodE 


\begin{tabular}{|l|l|l|l|l|l|l|}
\hline & $\begin{array}{l}\text { State Const. } \\
\text { Impediment- } \\
\text { Voter } \\
\text { Qualifications }\end{array}$ & $\begin{array}{l}\text { State Legislative } \\
\text { Impediment- } \\
\text { Voter Qualifica- } \\
\text { tions } 301\end{array}$ & $\begin{array}{l}\text { State Const. } \\
\text { Impediment- } \\
\text { Lack of Home } \\
\text { Rule 302 }\end{array}$ & $\begin{array}{l}\text { Specific Statute } \\
\text { Allows } \\
\text { Localities to } \\
\text { Impediment- } \\
\text { Lack of Home } \\
\text { Rule303 }\end{array}$ & $\begin{array}{l}\text { Enfranchise } \\
\text { Nonresidents in } \\
\text { Certain } \\
\text { Elections }\end{array}$ & $\begin{array}{l}\text { No Clear } \\
\text { Impediments }\end{array}$ \\
\hline Missouri & & & & $\mathrm{X}^{340 *}$ & & \\
\hline Montana & & $\mathrm{X}^{341}$ & & $\mathrm{X}^{342}$ & & \\
\hline Nebraska & & $\mathrm{X}^{343}$ & & & $\mathrm{X}^{344}$ & \\
\hline Nevada & & & & & $\mathrm{X}^{345 *}$ \\
\hline
\end{tabular}

AnN. § 23-15-11 (2017) (Mississippi’s online code is maintained by Lexis and does not allow for direct links to individual provisions, but the full code is available at http://www.lexisnexis.com/ hottopics/mscode/). Yet Mississippi's code prohibits municipalities from altering the "requirements, practices, or procedures for municipal elections." Miss. CoDE. AnN. § 21-17-5(2) (2017).

340 Missouri's constitution and laws phrase the right to vote as a grant (except for felons and those adjudicated mentally incompetent). See Mo. Const. art. VIII, § 2; Mo. Rev. Stat. $\S 115.133$ (2017), http://www.moga.mo.gov/mostatutes/stathtml/11500001331.html. Missouri's constitution provides cities "all powers which the general assembly of the state of Missouri has authority to confer upon any city." Mo. Const. art. VI, § 19(a). Missouri's election code explicitly grants any city with a population over 400,000 the power to regulate its own elections. Mo. Rev. STAT. § 122.650 (2017), http://www.moga.mo.gov/mostatutes/stathtml/12200006501.ht $\mathrm{ml}$ ?\&me=122.650. Reading the two statutes together suggests that cities with a population below 400,000 do not have the authority to expand voter qualifications. Only Kansas City has a population over 400,000. See QuickFacts: Kansas City city, Missouri, supra note 240. Thus, Kansas City, but not any other Missouri municipality, may enact local voter qualification rules for city elections.

341 Montana's constitution phrases the right to vote as a grant, except for felons. See MonT. Const. art. IV, § 2. However, Montana's election code phrases the right to vote as a restriction. See Mont. Code AnN. § 13-1-111 (2017), http://leg.mt.gov/bills/mca/title_0130/chapter_0010/ part_0010/section_0110/0130-0010-0010-0110.html.

342 Montana's home rule statute states that municipalities are subject to Montana's election code. Mont. CodE AnN. § 7-3-708 (2017), http://leg.mt.gov/bills/mca/title_0070/chapter_0030/ part_0070/section_0080/0070-0030-0070-0080.html.

343 Nebraska's constitution phrases the right to vote as a grant, but its election code phrases the right to vote as a restriction. See Neb. Const. art. VI, § 1; Neb. Rev. Stat. § 32-110 (2017), http://nebraskalegislature.gov/laws/statutes.php?statute=32-110. Nebraska law allows a city with a population greater than 5,000 to adopt a home rule charter so long as it is "consistent with and subject to the constitution and laws of this state." NEB. Const. art. XI, § 2 .

344 Neb. Rev. STAt. § 31-407 (2017), http://nebraskalegislature.gov/laws/statutes.php?stat ute $=31-407$.

345 Nevada's constitution and election code phrase the right to vote as a grant. See NEv. Const. art. II, § 1; Nev. Rev. STAt. § 293.485 (2017), https://www.leg.state.nv.us/nrs/NRS-293.ht ml\#NRS293Sec485. Nevada's home rule statute gives cities certain enumerated powers, but does not list authority over local elections as one such power. See Nev. Rev. Stat. § 268.008 (2017), https://www.leg.state.nv.us/nrs/NRS-268.html\#NRS268Sec008. However, Nevada's election code does give cities the power to "do all other things required to carry the election into effect," which strongly suggests they may have the authority to enact voter qualifications for local elections. Nev. Rev. Stat. § 293C.110 (2017), https://www.leg.state.nv.us/nrs/NRS-293C.html \#NRS293CSec110. Judicial interpretation may be helpful. 


\begin{tabular}{|c|c|c|c|c|c|c|}
\hline State & $\begin{array}{l}\text { State Const. } \\
\text { Impediment- } \\
\text { Voter } \\
\text { Qualifications } \\
\end{array}$ & $\begin{array}{l}\text { State Legislative } \\
\text { Impediment- } \\
\text { Voter Qualifica- } \\
\text { tions } 301 \\
\end{array}$ & $\begin{array}{l}\text { State Const. } \\
\text { Impediment- } \\
\text { Lack of Home } \\
\text { Rule }^{302} \\
\end{array}$ & $\begin{array}{l}\text { State Legislative } \\
\text { Impediment- } \\
\text { Lack of Home } \\
\text { Rule }^{303} \\
\end{array}$ & \begin{tabular}{|l|} 
Specific Statute \\
Allows \\
Localities to \\
Enfranchise \\
Nonresidents in \\
Certain \\
Elections \\
\end{tabular} & \begin{tabular}{|l|l} 
No Clear \\
Impediments
\end{tabular} \\
\hline $\begin{array}{l}\text { New } \\
\text { Hampshire }\end{array}$ & & $\mathrm{X}^{346}$ & & $\mathrm{X}^{347 *}$ & & \\
\hline New Jersey & & & & & & $\mathrm{X}^{348}$ \\
\hline New Mexico & & & & & $\mathrm{X}^{349}$ & $\mathrm{X}^{350}$ \\
\hline New York & & $\mathrm{X}^{351}$ & & $\mathrm{X}^{352}$ & & \\
\hline $\begin{array}{l}\text { North } \\
\text { Carolina }\end{array}$ & & $X^{353}$ & & $X^{354}$ & & \\
\hline
\end{tabular}

346 New Hampshire's constitution and law phrase the right to vote as a grant. See N.H. Const., Bill of Rights, art. 11; N.H. Rev. Stat. Ann. § 654:1 (2017), http://www.gencourt.state. nh.us/rsa/html/LXIII/654/654-1.htm. New Hampshire's code provides that those who are qualified to vote under New Hampshire's election law are also qualified to vote in city elections. N.H. Rev. Stat. AnN. § 49-C:5 (2017), http://www.gencourt.state.nh.us/rsa/html/III/49-C/49-C5.htm. Thus, voter qualifications in local elections are tied directly to state voter qualification rules. Accordingly, even though the constitution and statutes phrase the right to vote as a grant, they still delineate specific voter qualifications that apply to local elections as well.

347 Although New Hampshire's home rule statute grants cities certain powers, it does not grant the power to change voter qualifications. See N.H. Rev. StAt. Ann. § 49-C:15 (2017), $\mathrm{http}: / /$ www.gencourt.state.nh.us/rsa/html/III/49-C/49-C-15.htm. It is not clear if this omission means that there is no authority for local governments to enact local voter qualification rules.

348 New Jersey's constitution and code phrase the right to vote as a grant. See N.J. ConsT. art. II, § 1, para. 3; N.J. STAT. AnN. § 19:4-1 (West 2017), http://njlaw.rutgers.edu/cgi-bin/njstats/ showsect.cgi?section=19\%3A4-1\&actn=getsect. The Rutgers source is listed by the New Jersey Attorney General's website as a source of the State's statutes. Statutes, Regulations \& Rules, N.J. OfF. АтT'y GeN., http://www.nj.gov/oag/statutes-regulations-rules.html [https://perma.cc/7TEN2WCX]. Furthermore, New Jersey's home rule statute confers broad powers to local governments. See N.J. StAT. AnN. § 40:69A-30 (West 2017), http://njlaw.rutgers.edu/cgi-bin/ njstats/showsect.cgi?section $=40 \% 3 \mathrm{~A} 69 \mathrm{~A}-30 \&$ actn $=$ getsect.

349 N.M. Stat. Ann. $\$ 73-18-30$ (2017) (New Mexico's online code is maintained by Conway Greene and does not allow for direct links to individual provisions, but the full code is available at http://public.nmcompcomm.us/nmpublic/gateway.dll/?f=templates\&fn=default.htm).

350 New Mexico's constitution and code phrase the right to vote as a grant. See N.M. Const. art. VII, § 1; N.M. Stat. Ann. § 49-3-5 (2017). Further, New Mexico's constitution and election code give municipalities the authority to regulate their own elections. See N.M. Const. art. X, § 6; N.M. STAt. AnN. § 3-8-1 (2017).

351 Although New York's constitution phrases the right to vote as a grant, the election code phrases it as a restriction. See N.Y. Const. art. II, § 1; N.Y. Elec. LAw § 5-102 (McKinney 2017) (New York's online code does not allow for direct links to individual provisions, but the full code is available at http://public.leginfo.state.ny.us/lawssrch.cgi?NVLWO:).

352 New York's election code provides that it is the sole source of law in regulating all New York elections, including local elections. ELEC. § 1-102.

353 Although North Carolina's constitution phrases the right to vote as a grant (except for felons), North Carolina's code phrases the right to vote as a restriction, at least for age and felon status. See N.C. Const. art. VI, §§ 1-3; N.C. Gen. Stat. § 163-55 (2017), http://www.ncleg.net/ EnactedLegislation/Statutes/PDF/BySection/Chapter_163/GS_163-55.pdf.

354 North Carolina does not explicitly provide home rule authority for elections. Furthermore, North Carolina's code has a section devoted solely to the regulation of municipal elections. N.C. GEN. STAT. §§ 163-291-163-306 (2017), http://www.ncleg.net/gascripts/Statutes/ 


\begin{tabular}{|c|c|c|c|c|c|c|}
\hline State & \begin{tabular}{|l} 
State Const. \\
Impediment- \\
Voter \\
Qualifications \\
\end{tabular} & $\begin{array}{l}\text { State Legislative } \\
\text { Impediment-- } \\
\text { Voter Qualifica- } \\
\text { tions }{ }^{301} \\
\end{array}$ & $\begin{array}{l}\text { State Const. } \\
\text { Impediment- } \\
\text { Lack of Home } \\
\text { Rule }^{302} \\
\end{array}$ & $\begin{array}{l}\text { State Legislative } \\
\text { Impediment- } \\
\text { Lack of Home } \\
\text { Rule }^{303}\end{array}$ & \begin{tabular}{|l} 
Specific Statute \\
Allows \\
Localities to \\
Enfranchise \\
Nonresidents in \\
Certain \\
Elections \\
\end{tabular} & \begin{tabular}{|l}
$\begin{array}{l}\text { No Clear } \\
\text { Impediments }\end{array}$ \\
\end{tabular} \\
\hline $\begin{array}{l}\text { North } \\
\text { Dakota }\end{array}$ & & & & $X^{355}$ & & \\
\hline Ohio & & & & & & $\mathrm{X}^{356}$ \\
\hline Oklahoma & & & & & & $\mathrm{X}^{357}$ \\
\hline Oregon & & & & $\mathrm{X}^{358}$ & $\mathrm{X}^{359}$ & \\
\hline Pennsylvania & $\mathrm{X}^{360}$ & & & $\mathrm{X}^{361}$ & & \\
\hline Rhode Island & & & & & & $X^{362}$ \\
\hline
\end{tabular}

StatutesTOC.pl?Chapter=0163. Accordingly, municipalities likely lack home rule power to expand voter qualifications.

355 North Dakota's constitution and statutes phrase the right to vote as a grant. See N.D. Const. art. II, § 1; N.D. CENT. CODE § 16.1-01-04 (2017), http://www.legis.nd.gov/cencode/t161c01.pdf. Although North Dakota's home rule statute provides broad powers to municipalities, including giving them the authority to regulate local elections, it specifically exempts rules on voter qualifications'zN.D. CENT. CODE $§ \S 40-05.1-06,11-09.1-05$ (2017), http://www.legis.nd.gov/ cencode/t40c05-1.pdf, http://www.legis.nd.gov/cencode/t11c09-1.pdf.

356 Ohio's constitution and code phrase the right to vote as a grant. See OHio Const. art. V, § 1; Ohio Rev. Code AnN. § 3503.07 (LexisNexis 2017), http://codes.ohio.gov/orc/3503.07v1. In regard to home rule, Ohio municipalities have the "authority to exercise all powers of local self-government," which presumably includes voter qualification rules for local elections. OHIO Const. art. XVIII, § 3.

357 Both Oklahoma's constitution and code phrase the right to vote as a grant. See OKLA. Const. art. III, § 1; Окца. Sтат. tit. 26, § 4-101 (2017) (Oklahoma's online code does not allow for direct links to individual provisions, but the full code is available at http:// www.oklegislature.gov/osstatuestitle.html). Oklahoma's constitution provides broad home rule powers to municipalities with a population over 2,000. See OKLA. Const. art. XVIII, § 3(a).

358 Both Oregon's constitution and code phrase the right to vote as a grant. See Or. CONST. art. II, § 2; OR. REv. STAT. § 247.002(2) (2017), https://www.oregonlegislature.gov/bills_laws/ors/ ors247.html. But Oregon's election code requires municipalities to conduct their elections pursuant to the state election code, which likely prevents municipalities from expanding the voter rolls. OR. REv. STAT. § 254.016 (2017), https://www.oregonlegislature.gov/bills_laws/ors/ ors254.html.

359 Or. Rev. STAt. $\$ 545.207$ (2017), https://www.oregonlegislature.gov/bills_laws/ors/ors5 45.html.

360 Pennsylvania's constitution and election code both phrase the right to vote as a grant, but they require voters to be U.S. citizens as well as residents of the state. See PA. Const. art. VII, § 1; 25 PA. Cons. Stat. § 1301 (2017), http://www.legis.state.pa.us/cfdocs/legis/LI/cons Check.cfm?txtType $=$ HTM \& ttl $=25 \& \operatorname{div}=0 \& \operatorname{chpt}=13 \& \operatorname{sctn}=1 \& \operatorname{subsctn}=0$. Thus, the constitution and statutes would allow a Pennsylvania city to lower the voting age, but not to expand voting to noncitizens or nonresidents.

361 Pennsylvania's home rule statute explicitly denies municipalities power over the registration of electors or the conduct of elections. 53 PA. Cons. STAT. § 2962(a)(5) (2017), http:/ /www.legis.state.pa.us/cfdocs/legis/LI/consCheck.cfm?txtType=HTM\&ttl=53\&div=0\&chpt=29\& $\operatorname{sctn}=62 \& \operatorname{subsctn}=0$.

362 Both Rhode Island's constitution and code phrase the right to vote as a grant. See R.I. Const. art. II, § 1; 17 R.I. GEN. LAws § 17-1-3 (2017), http://webserver.rilin.state.ri.us/Statutes/ TITLE17/17-1/17-1-3.htm. Rhode Island's constitution also grants municipalities broad home rule powers. See R.I. Const. art. XIII, § 2. 


\begin{tabular}{|c|c|c|c|c|c|c|}
\hline State & $\begin{array}{l}\text { State Const. } \\
\text { Impediment- } \\
\text { Voter } \\
\text { Qualifications } \\
\end{array}$ & $\begin{array}{l}\text { State Legislative } \\
\text { Impediment- } \\
\text { Voter Qualifica- } \\
\text { tions } 301\end{array}$ & $\begin{array}{l}\text { State Const. } \\
\text { Impediment- } \\
\text { Lack of Home } \\
\text { Rule }^{302}\end{array}$ & $\begin{array}{l}\text { State Legislative } \\
\text { Impediment- } \\
\text { Lack of Home } \\
\text { Rule }^{303}\end{array}$ & $\begin{array}{l}\text { Specific Statute } \\
\text { Allows } \\
\text { Localities to } \\
\text { Enfranchise } \\
\text { Nonresidents in } \\
\text { Certain } \\
\text { Elections } \\
\end{array}$ & $\begin{array}{l}\text { No Clear } \\
\text { Impediments }\end{array}$ \\
\hline $\begin{array}{l}\text { South } \\
\text { Carolina }\end{array}$ & & & $\mathrm{X}^{363}$ & & & \\
\hline $\begin{array}{l}\text { South } \\
\text { Dakota }\end{array}$ & & & & & & $\mathrm{X}^{364}$ \\
\hline Tennessee & & & & $\mathrm{X}^{365 *}$ & $\mathrm{X}^{366}$ & \\
\hline Texas & $\mathrm{X}^{367}$ & $\mathrm{X}^{368}$ & & & & \\
\hline Utah & & & $\mathrm{X}^{369}$ & & & \\
\hline Vermont & & & & $\mathrm{X}^{370 *}$ & & \\
\hline
\end{tabular}

363 Although South Carolina's constitution and code phrase the right to vote as a grant, South Carolina's constitution expressly prohibits municipalities from altering "election and suffrage qualifications.” See S.C. Const. art. II, § 4; id. art. VIII, § 14; S.C. Code AnN. § 7-5-610 (2017), http://www.scstatehouse.gov/code/t07c005.php.

364 South Dakota's constitution and code phrase the right to vote as a grant. See S.D. Const. art. VII, § 2; S.D. CoDIFIED Laws § 12-3-1 (2017), http://sdlegislature.gov/Statutes/ Codified_Laws/DisplayStatute.aspx?Type=statute \&Statute=12-3-1. South Dakota's constitution also gives municipalities broad home rule authority. See S.D. Const. art. IX, § 2.

365 Tennessee's constitution and code phrase the right to vote as a grant. See Tenn. Const. art. IV, § 1; Tenn. Code AnN. § 2-2-102 (2017) (Tennessee's online code does not allow for direct links to individual provisions, but the full code is available at http://www.lexisnexis.com/ hottopics/tncode/). Tennessee's constitution also authorizes home rule. TENN. Const. art. XI, $\S 9$. However, Tennessee's home rule statute specifically lists municipalities' home rule powers and does not include the expansion of voter qualifications. See Tenn. Code Ann. § 6-54 (2017). Considering that there is a specific list of home rule powers and a lack of an express grant of authority with regard to voter qualifications, it is unclear whether a Tennessee municipality may expand the voter rolls for local elections. Judicial interpretation would be helpful.

366 Tenn. Code Ann. § 2-6-205 (2017).

367 The Texas Constitution explicitly prohibits certain people from voting, such as those under eighteen years old, those deemed mentally incompetent, and felons. TEx. Const. art. VI, $\S \S 1,2$. The constitution also provides that anyone "who is a citizen of the United States and who is a resident of this State shall be deemed a qualified voter," which might be considered a grant for these categories. Id. As to home rule, the Texas Constitution allows cities with a population of more than 5,000 to adopt home rule charters, but "no charter or any ordinance passed under said charter shall contain any provision inconsistent with the Constitution of the State, or of the general laws enacted by the Legislature of this State." Id. art. XI, $§ 5$.

368 Texas law defines a "qualified voter" using specific criteria such as age, citizenship, and residence. Tex. Elec. Code ANN. $\$ 11.002$ (West 2017), http://www.statutes.legis.state.tx.us/ Docs/EL/htm/EL.11.htm\#11.002.

369 Utah's constitution and code phrase the right to vote as a grant, but state law requires any person voting in a municipal election to have been duly registered based on the state's voter qualification rules. See Utah Const. art. IV, § 2; Utah Code Ann. § 20A-2-101 to 102 (LexisNexis 2017), https:/le.utah.gov/xcode/Title20A/Chapter2/20A-2-S101.html?v=C20A-2S101_1800010118000101, https://le.utah.gov/xcode/Title20A/Chapter2/20A-2-S102.html?v=C20A -2-S102_2014040320140513. Utah's constitution grants municipalities broad home rule powers. See UTAh Const. art. XI, § 5 .

370 Vermont's constitution and statutes phrase the right to vote as a grant. See VT. Const. ch. 2, § 42; Vт. Stat. AnN. tit. 17, § 2121 (2017), http://legislature.vermont.gov/statutes/section/ 17/043/02121. Vermont's home rule statute provides for municipalities to amend their charters, but requires the city's voters and the state's General Assembly to approve any amendments. VT. 


\begin{tabular}{|c|c|c|c|c|c|c|}
\hline State & $\begin{array}{l}\text { State Const. } \\
\text { Impediment- } \\
\text { Voter } \\
\text { Qualifications } \\
\end{array}$ & $\begin{array}{l}\text { State Legislative } \\
\text { Impediment- } \\
\text { Voter Qualifica- } \\
\text { tions } 301 \\
\end{array}$ & $\begin{array}{l}\text { State Const. } \\
\text { Impediment- } \\
\text { Lack of Home } \\
\text { Rule }^{302} \\
\end{array}$ & $\begin{array}{l}\text { State Legislative } \\
\text { Impediment- } \\
\text { Lack of Home } \\
\text { Rule }^{303} \\
\end{array}$ & \begin{tabular}{|l} 
Specific Statute \\
Allows \\
Localities to \\
Enfranchise \\
Nonresidents in \\
Certain \\
Elections \\
\end{tabular} & \begin{tabular}{|l} 
No Clear \\
Impediments
\end{tabular} \\
\hline Virginia & $\mathrm{X}^{371}$ & $\mathrm{X}^{372}$ & & & & \\
\hline Washington & & & & & & $\mathrm{X}^{373}$ \\
\hline $\begin{array}{l}\text { Washington, } \\
\text { D.C. }\end{array}$ & & & & & & $\mathrm{X}^{374}$ \\
\hline $\begin{array}{l}\text { West } \\
\text { Virginia }\end{array}$ & $\mathrm{X}^{375}$ & $\mathrm{X}^{376}$ & & & & \\
\hline Wisconsin & & & & & & $\mathrm{X}^{377}$ \\
\hline
\end{tabular}

StAt. AnN. tit. 17, § 2645 (2017), http://legislature.vermont.gov/statutes/section/17/055/02645. Accordingly, a municipality could expand voter qualifications, but it would have to secure state legislative approval.

371 Virginia's constitution phrases voter qualifications as a restriction. See VA. Const. art. II, $\S 1$.

372 Virginia law mimics the state constitution in listing voter qualifications as a restriction and adds the limitations that voters must be at least eighteen years old, not convicted of felonies, and not adjudicated as "incapacitated." VA. CoDE. AnN. §24.2-101 (2017), http:// law.lis.virginia.gov/vacode/title24.2/chapter1/section24.2-101/. Regarding home rule, Virginia's law appears to grant localities home rule authority for "powers pertinent to the conduct of the affairs and functions of the municipal government.” VA. CODE. ANN. § 15.2-1102 (2017), http:// law.lis.virginia.gov/vacode/title15.2/chapter11/section15.2-1102/.

373 Washington's constitution phrases the right to vote as a grant, while its election code simply refers to the state constitution for voter qualifications. See WAsH. Const. art. VI, § 1; WASH. REv. CodE § 29A.04.061 (2017), https://app.leg.wa.gov/rcw/default.aspx?cite=29A.04 .061. Furthermore, Washington's election code grants broad home rule powers to "first class" cities as it relates to elections. See WASH. REv. CODE $\$ 35.22 .280$ (2017), http://app.leg.wa.gov/ rcw/default.aspx? cite=35.22.280.

374 Congress has granted Washington, D.C., the power to legislate on "all rightful subjects of legislation," which likely includes the right to expand voter qualifications. D.C. CODE § 1203.02 (2017), https://beta.code.dccouncil.us/dc/council/code/sections/1-203.02.html. However, Congress has the power to repeal such action. Id. §1-206.01 (2017), https://beta.code.dccouncil .us/dc/council/code/sections/1-206.01.html.

375 The West Virginia Constitution discusses voter qualifications as restrictions and lists several groups who may not vote, including "minors," those judged mentally incompetent, nonresidents, and felons. W. VA. ConsT. art. IV, $§ 1$. It does not say anything, however, about U.S. citizenship.

376 The West Virginia Code mimics the state constitution in listing voter qualifications as restrictions but also more specifically says that those under eighteen years old may not vote except in a primary election if the voter will be eighteen by the general election. W. VA. CODE $\S 3-1-3$ (2017), http://www.legis.state.wv.us/wvcode/Code.cfm?chap=03\&art=1. As to home rule, West Virginia provides broad home rule authority so long as local law is not inconsistent with the state constitution or state laws. See W. VA. CoDE § 8-12-2 (2017), http://www.legis.state.wv.us/ wvcode/Code.cfm?chap=08\&art $=12$. There would be no home rule impediment if West Virginia amended its constitution and state law on voter qualifications.

377 Wisconsin's constitution and code phrase the right to vote as a grant. See Wis. Const. art. III, § 1; WIS. STAт. § 6.02 (2017), http://docs.legis.wisconsin.gov/statutes/statutes/6/I/02. Wisconsin's constitution also grants municipalities broad home rule power. See Wis. Const. art. $\mathrm{XI}, \S 3$. 


\begin{tabular}{|c|c|c|c|c|c|c|}
\hline State & $\begin{array}{l}\text { State Const. } \\
\text { Impediment- } \\
\text { Voter } \\
\text { Qualifications }\end{array}$ & $\begin{array}{l}\text { State Legislative } \\
\text { Impediment-- } \\
\text { Voter Qualifica- } \\
\text { tions }{ }^{301}\end{array}$ & $\begin{array}{l}\text { State Const. } \\
\text { Impediment- } \\
\text { Lack of Home } \\
\text { Rule }^{302}\end{array}$ & $\begin{array}{l}\text { State Legislative } \\
\text { Impediment- } \\
\text { Lack of Home } \\
\text { Rule } 303\end{array}$ & $\begin{array}{l}\text { Specific Statute } \\
\text { Allows } \\
\text { Localities to } \\
\text { Enfranchise } \\
\text { Nonresidents in } \\
\text { Certain } \\
\text { Elections }\end{array}$ & $\begin{array}{l}\text { No Clear } \\
\text { Impediments }\end{array}$ \\
\hline Wyoming & & & & $\mathrm{X}^{378}$ & $\mathrm{X}^{379}$ & \\
\hline
\end{tabular}

378 Wyoming's constitution and code phrase the right to vote as a grant (except for felons and those "adjudicated to be mentally incompetent"). See Wyo. Const. art. VI, §§ 2, 6; Wyo. Stat. Ann. § 22-1-102(xxvi) (2017) (Wyoming's online code does not allow for direct links to individual provisions, but the full code is available at http://legisweb.state.wy.us/NXT/gateway.dll ?f=templates\&fn=default.htm). But with regard to home rule, Wyoming's election code provides that the state's election rules also govern municipal elections, thereby limiting municipal voting laws. Wyo. Stat. Ann. §§ 22-2-101, 22-23-101 (2017).

379 Wyo. Stat. Ann. § 41-7-317 (2017). 